\author{
Monograph \\ urn:1sid:zoobank.org:pub:3F0B6EAF-C616-4865-811A-414A094B590C
}

\title{
Taxonomic revision of the Phanaeus endymion species group (Coleoptera: Scarabaeidae), with the descriptions of five new species
}

\author{
Victor MOCTEZUMA $^{1, *} \&$ Gonzalo HALFFTER ${ }^{2}$ \\ ${ }^{1,2}$ Red de Ecoetología, Instituto de Ecología, A.C. Carretera antigua a Coatepec 351, \\ El Haya, Xalapa, Veracruz 91073, Mexico. \\ *Corresponding author: abadonjvpm@hotmail.com \\ 2Email: gonzalohalffter@inecol.mx \\ ${ }^{1}$ urn:1sid:zoobank.org:author:B672EF02-4113-480E-B297-F0158D11DF4A \\ ${ }^{2}$ urn:1sid:zoobank.org:author:CF2EF74E-878A-4BC8-82A2-01F669049650 \\ $1 \odot$ https://orcid.org/0000-0002-4532-0302 \\ $2 \odot$ https://orcid.org/0000-0003-1430-7049
}

\begin{abstract}
The Phanaeus endymion species group is defined as a lineage of dung beetles distributed from Mexico to Ecuador. The current arrangement of the $P$. endymion species group includes 18 species (five newly described and three revalidated herein): P. arletteae Arnaud, 2018; P. bravoensis Moctezuma, Sánchez-Huerta \& Halffter, 2017; P. chiapanecus sp. nov.; P. edmondsi Moctezuma, Deloya \& Halffter, 2019; P. endymion Harold, 1863; P. funereus Balthasar, 1939 stat. rev.; P. halffterorum Edmonds, 1979; P. huichol Moctezuma, Sánchez-Huerta \& Halffter, 2017; P. jackenioi sp. nov.; P. malyi Arnaud, 2002; P. olsoufieffi Balthasar, 1939 stat. rev.; P. pacificus sp. nov.; P. panamensis sp. nov.; P. porioni Arnaud, 2001 stat. rev.; P. pyrois Bates, 1887; P. rzedowskii sp. nov.; P. zapotecus Edmonds, 2006; and P. zoque Moctezuma \& Halffter, 2017. Phanaeus dionysius Kohlmann, Arriaga-Jiménez \& Rös, 2018 syn. nov. is considered as a new junior subjective synonymy of $P$. zapotecus Edmonds, 2006. Phanaeus blanchardi Olsoufieff, 1924 and $P$. bothrus Blackwelder, 1944 are junior objective synonyms of $P$. olsoufieffi Balthasar, 1939 stat. rev.
\end{abstract}

Keywords. Phanaeini, rainbow scarab dung beetles, genital diversification, mandible evolution, symbiotic interactions.

Moctezuma V. \& Halffter G. 2021. Taxonomic revision of the Phanaeus endymion species group (Coleoptera: Scarabaeidae), with the descriptions of five new species. European Journal of Taxonomy 747: 1-71. https://doi.org/10.5852/ejt.2021.747.1333

\section{Introduction}

The Phanaeus endymion species group is a lineage of rainbow scarab dung beetles distributed from Mexico to Ecuador (Edmonds 1994; Edmonds \& Zídek 2012; Lizardo et al. 2017). Species within the $P$. endymion species group are of great ecological importance since most of them are typically associated with Mesoamerican forests (Edmonds 1994, 2003; Arellano et al. 2008, 2013; Huerta et al. 
2016; Moctezuma \& Halffter 2017; Moctezuma et al. 2017, 2019; Kohlmann et al. 2018), and are either coprophagous, necrophagous or mycophagous (Edmonds 1994, 2003, 2006; Deloya et al. 2013; Moctezuma \& Halffter 2017; Moctezuma et al. 2017; Gillett \& Toussaint 2020).

The P. endymion species group has been classified within the subgenus Notiophanaeus Edmonds, 1994. According to Edmonds (1994) the pronotal sculpturing is the main distinction between Notiophanaeus (glassy and smooth) and Phanaeus Macleay, 1819 (heavily rugose). Nevertheless, phylogenetic studies have demonstrated that both Notiophanaeus and Phanaeus are non-monophyletic groups (Price 2007, 2009; Gillett \& Toussaint 2020). Within Notiophanaeus, the P. endymion species group is mainly distinguished by the anterior margin of clypeus strongly bidentate medially, and pronotum of larger males with triangular disc and prominent posterolateral angles (Edmonds 1994). The monophyly of the P. endymion species group has been supported by previous phylogenetic studies (Price 2007, 2009; Gillett \& Toussaint 2020).

Within the dung beetle genus Phanaeus, the $P$. endymion species group is probably the best studied in recent years (Edmonds \& Zídek 2012; Solís \& Kohlmann 2012; Moctezuma \& Halffter 2017; Moctezuma et al. 2017, 2019; Arnaud 2018; Kohlmann et al. 2018). Nevertheless, several taxonomic issues remain to be disentangled. The complex background of taxonomy of the $P$. endymion species group is summarized herein. Phanaeus endymion Harold, 1863 was the first species to be described, based upon specimens from Orizaba, Veracruz, Mexico (Harold 1863). Subsequently, P. pyrois Bates, 1887 was described in the Biologia Centrali-Americana (Bates 1887). Bates (1887) suggested that $P$. endymion and P. pyrois were closely related species, and four chromatic morphs from Nicaragua, Panama and Colombia were included within $P$. pyrois (the original description of this species was illustrated with specimens from Chontales, Nicaragua).

During the $20^{\text {th }}$ century, a proliferation of names and synonyms within the $P$. endymion species group began. Olsoufieff (1924) described P. blanchardi Olsoufieff, 1924 based upon black specimens from Valle del Cauca, Colombia; and proposed the aberration viridicollis for green specimens from Ecuador. Subsequently, Balthasar (1939) described P. funereus Balthasar, 1939 from Ecuador; and recognized that $P$. blanchardi was a junior primary homonym of P. blanchardi Harold, 1871. As a consequence, Balthasar (1939) proposed the name P. olsoufieffi Balthasar, 1939 in replacement of Olsoufieff's P. blanchardi. Nonetheless, Blackwelder (1944-1957) also recognized the homonymy of P. blanchardi and proposed the replacement name P. bothrus Blackwelder, 1944. Martínez \& Pereira (1967) suggested $P$. bothrus as a junior objective synonym of $P$. olsoufieffi, but they considered $P$. olsoufieffi as a junior subjective synonym of $P$. funereus. According to Martínez \& Pereira (1967), both P. olsoufieffi and $P$. funereus were identical in morphology, except for the aberration viridicollis that might be a valid subspecies. Afterwards, P. halffterorum Edmonds, 1979 was described based upon specimens from Mexico (Edmonds 1979), and the lectotypes for P. endymion and Olsoufieff's P. blanchardi (currently referred to as $P$. olsoufieffi) were designated by Arnaud (1982).

At the end of the $20^{\text {th }}$ century, Edmonds (1994) revised the genus Phanaeus, defined the P. endymion species group, and designated a lectotype for $P$. pyrois. Edmond's concept of the $P$. endymion species group included within it three species: $P$. endymion, $P$. pyrois and $P$. halffterorum; while $P$. funereus and P. olsoufieffi where considered as junior subjective synonyms of P. pyrois (Edmonds 1994). According to Edmonds (1994), specimens of P. pyrois, P. funereus and P. olsoufieffi were virtually identical in external morphology and did not merit a separate taxonomic status. Edmonds (1994) considered that Olsoufieff's aberrant viridicollis might be a valid taxon, but indicated that more studies were needed to confirm or refute this assumption. Additionally, Edmonds (1994) suggested that blue and green specimens from Costa Rica might be hybrids of P. pyrois with P. endymion. 
The beginning of the $21^{\text {st }}$ century was distinguished by a controversial application of the subspecieslevel taxa in the P. endymion species group (and in the entire genus Phanaeus). Thereby, the subspecies P. endymion porioni Arnaud, 2001 was described from Honduras and Belize (Arnaud 2001), while P. pyrois malyi Arnaud, 2002 was proposed for specimens from the southern Pacific of Costa Rica (Arnaud 2002a). Additionally, Arnaud (2002b) considered P. olsoufieffi and P. funereus as subspecies of $P$. pyrois, and proposed Olsoufieff's aberrant viridicollis as a valid species ( $P$. viridicollis Olsoufieff, 1924). Subsequently, P. zapotecus Edmonds, 2006 was described from Mexico and included within the P. endymion species group (Edmonds 2006); while P. pyrois malyi was elevated to full species status based on the results of DNA analyses of specimens from Costa Rica (Solís \& Kohlmann 2012).

Later, the taxonomy of Phanaeus was updated and the avoidance of the subspecies category was suggested by Edmonds \& Zídek (2012). As a consequence, several nomenclatural changes were proposed and resulted in the $P$. endymion species group sensu Edmonds \& Zídek (2012) including four species: P. endymion, P. pyrois, P. halffterorum and P. zapotecus. Phanaeus viridicollis was considered an unavailable name referable to a chromatic morph of $P$. pyrois: the name viridicollis was originally proposed as an infrasubspecific taxon (aberration), while some doubtful specimens of $P$. viridicollis were collected from Nicaragua along with the typical P. pyrois (Edmonds \& Zídek 2012). Additionally, the following junior subjective synonyms were recognized by Edmonds \& Zídek (2012): P. endymion porioni $=$ P. endymion; $P$. pyrois funereus Balthasar, $1939=P$. pyrois, $P$. pyrois olsoufieffi Balthasar, $1939=$ P. pyrois, and P. pyrois malyi $=$. pyrois. Edmonds \& Zídek (2012) argued that the taxonomic recognition of $P$. endymion porioni was not justified by the morphological differences identified by Arnaud (2001). Additionally, they refused to recognize $P$. malyi as a valid species, because the analysis of Solís \& Kohlmann (2012) did not include samples of the Panamanian and South American populations and chromatic morphs of $P$. pyrois (Edmonds \& Zídek 2012).

Traditionally, the taxonomy of the New World genus Phanaeus has relied on the study of the external morphology (Bates 1887; Olsoufieff 1924; Edmonds 1994; Arnaud 2002b; Edmonds \& Zídek 2012). Particularly, the secondary sexual features of major males are considered to be reliable for determining species, while the study of the genital structures has been largely neglected (Edmonds 1994; Arnaud 2002b; Edmonds \& Zídek 2012). The morphology of the aedeagus is usually not taxonomically informative enough to separate closely related species of Phanaeus (Edmonds 1994; Arnaud 2002b; Price 2005; Moctezuma \& Halffter 2017; Moctezuma et al. 2017, 2019, 2020). Nevertheless, the structures of the internal sack of the aedeagus have proved to be valuable for the study of the taxonomy of Scarabaeinae dung beetles (Tarasov \& Solodovnikov 2011; Medina et al. 2013; Tarasov \& Génier 2015).

Previous authors have provided illustrations of the aedeagus (Olsoufieff 1924; Halffter 1955; Edmonds 1972; Howden \& Young 1981; Arnaud 2000, 2001; Price 2005; Marchisio \& Zunino 2012; Manjarres-H \& Molano-R 2015; Moctezuma \& Halffter 2017; Moctezuma et al. 2017, 2019, 2020; Kohlmann et al. 2018), internal sac of aedeagus (Price 2005; Manjarres-H \& Molano-R 2015; Moctezuma \& Halffter 2017), dissected endophallites (Price 2005; Marchisio \& Zunino 2012; Manjarres-H \& Molano-R 2015; Tarasov \& Génier 2015; Moctezuma \& Halffter 2017; Moctezuma et al. 2017, 2019, 2020; Kohlmann et al. 2018) and spermathecae (Halffter \& Edmonds 1982; López-Guerrero \& Halffter 2000; Price 2005; Marchisio \& Zunino 2012) for some species of Phanaeus. However, the first serious attempt to describe the genitalia of Phanaeus for taxonomic purposes was by Price (2005), who examined the aedeagus, endophallites and spermathecae for the $P$. vindex species group. In a subsequent work, Manjarres- $\mathrm{H} \&$ Molano-R (2015) examined and described the male genitalia of the Colombian Phanaeus (and other Phanaeini). They suggested that examination of the endophallites has taxonomic value for Phanaeus, because these structures show an adequate degree of interspecific heterogeneity and intraspecific homogeneity (Manjarres-H \& Molano-R 2015). 
Taking into account the incipient study of the genital morphology of Phanaeus to separate closely related species (Price 2005; Manjarres-H. \& Molano-R. 2015), a majority of recent studies implemented the examination of the endophallites to identify and describe new species within the $P$. endymion species group. The description of $P$. zoque Moctezuma \& Halffter, 2017 was the first that relied on the examination and comparison of the external and genital morphology of the male to separate a new species from the typical P. endymion (Moctezuma \& Halffter 2017). Subsequently, Moctezuma et al. (2017) studied the male external and genital morphology of P. bravoensis Moctezuma, Sánchez-Huerta \& Halffter, 2017; P. huichol Moctezuma, Sánchez-Huerta \& Halffter, 2017; and P. halffterorum from Mexico. Arnaud (2018) described the new P. arletteae Arnaud, 2018 from Ecuador using external characters, based upon specimens of what was Olsoufieff's former aberration viridicollis. Later, Kohlmann et al. (2018) described P. dionysius Kohlmann, Arriaga-Jiménez \& Rös, 2018; and illustrated P. zapotecus. The illustration of the habitus and aedeagus for both $P$. dionysius and $P$. zapotecus was provided by Kohlmann et al. (2018); but they only figured the endophallite copulatrix of $P$. dionysius. Additionally, Kohlmann et al. (2018) revalidated P. malyi as a full species, based on the external morphology of black specimens from Costa Rica, Panama (incorrectly referred to as $P$. pyrois olsoufieffi) and Ecuador (referred to as $P$. pyrois funereus). Furthermore, they considered that a more detailed analysis would be required to resurrect $P$. pyrois olsoufieffi and $P$. pyrois funereus from previous synonymy (Kohlmann et al. 2018). The latest species to be described and included within the $P$. endymion species group was P. edmondsi Moctezuma, Deloya \& Halffter, 2019 from Mexico (Moctezuma et al. 2019).

In the face of this historical context, we aim to reassess the taxonomy of the P. endymion species group herein. Our study is based on two complementary sources of characters: the external morphology of males and females and the morphology of the endophallite copulatrix of males. Special emphasis is placed on P. pyrois and its taxonomically unsupported chromatic morphs (P. malyi, P. funereus, and $P$. olsoufieffi), and the status of $P$. e. porioni and P. dionysius is also revised. New species descriptions and redescriptions for previously described species are provided. Finally, a new determination key and images for the species within the $P$. endymion species group are provided.

\section{Material and methods}

The following entomological collections are used herein:

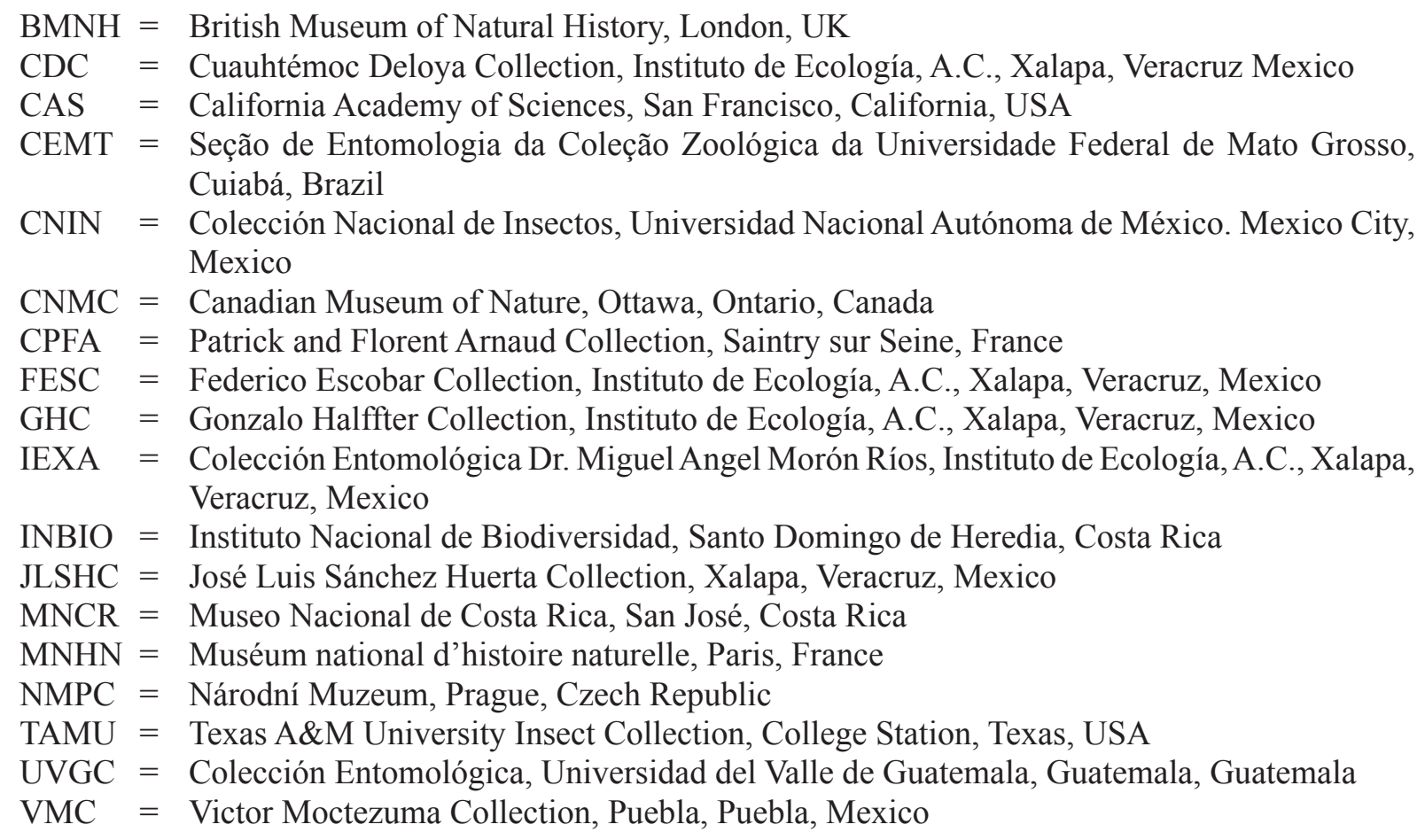


The phylogenetic species concept sensu Wheeler \& Platnick (2000) was adhered to, which defines a species as the smallest aggregation of (sexual) populations or (asexual) lineages that are diagnosable by a unique combination of character states. The subspecies-level is avoided for this work, while intraspecific variability of morphology (such as colouration, body size, and integument) is included within variation of the species. We followed the nomenclature proposed by Harris (1979), Edmonds (1994) and Cristóvão \& Vaz-de-Mello (2020) for external morphology and that of Moctezuma et al. (2017) for genital morphology, except for the term endophallite (Génier 2019). The subgenus-level is avoided for this study since Phanaeus and Notiophanaeus have been proven to be artificial groups (Price 2007, 2009; Gillett \& Toussaint 2020), and Notiophanaeus will probably be considered a synonym of Phanaeus in future works.

Type specimens bear determination labels printed on red acid-free paper, indicating the specimen's sex, and whether they are the holotype or paratypes. Label data is given verbatim. The genital structures were soaked with $10 \% \mathrm{KOH}$ solution for 24 hours at room temperature, then rinsed with $96 \%$ ethanol and later with water. These structures were permanently stored in $15 \mathrm{~mm}$ glass microvials (BioQuip Products, Inc., Rancho Dominguez, California, USA) with glycerol, and the microvials were pinned under the dissected specimens.

Measurements and pictures were taken using a Leica Z16APOA stereo microscope equipped with Leica Smart Touch and Leica DMC2900 camera (Leica, Wetzlar, Germany), using the manufacturer's software and the z-stack image capture method (except for Figs 4D, 5C, 8C, 11C, 12D, 18A, 19A). Since rainbow scarab dung beetles are usually iridescent (Edmonds 1994), the stereo microscope lightning was substituted (except for Figs 1,20) to obtain adequate colour images as follows: a cylinder made of matt drafting acetate functioned as a light diffuser, while a cylinder made of a rolled LED light strip (300 LEDs/ 5 m, 12 Vcc, white 6000-7000k, LED 3528, 13 W/h; Steren, Mexico City, Mexico) was used as light source. The final images were edited using a Wacom Intuos PEN tablet CTL-6100WL (Wacom Co., Ltd, Toyonodai Kazo-shi, Saitama, Japan) with Adobe Photoshop CC ver. 2015 (Adobe Systems Incorporated, San José, California, USA) and CorelDRAW X7 ver. 17.0.0.491 (Corel Corporation, Ottawa, Canada). Locality data were taken from specimen labels, literature and data bases (GBIF Secretariat 2019a; 2019b).

\section{Results}

\section{Taxonomy}

Phylum Arthropoda von Siebold, 1848

Subphylum Hexapoda Blainville, 1816

Class Insecta Linnaeus, 1758

Order Coleoptera Linnaeus, 1758

Suborder Polyphaga Emery, 1886

Superfamily Scarabaeoidea Latreille, 1802

Family Scarabaeidae Latreille, 1802

Subfamily Scarabaeinae Latreille, 1802

Genus Phanaeus Macleay, 1819

Phanaeus Macleay, 1819: 124.

Lonchophorus Germar, 1824: 106.

Phaneus Castelnau, 1840: 79.

Onthurgus Gistel, 1857: 90.

Palaeocopris Pierce, 1946: 130. 
Phanaeus - Brullé 1837: 302. — Dejean 1844: 155. — Agassiz 1846: 818. — Lacordaire 1856: 100. — Gemminger \& Harold 1869: 1016. — Lacordaire \& Chapuis 1876: 276. — Bates 1887: 387. — Nevinson 1892: 1. — Gillet 1911: 81. — Lucas 1920: 499. — Dawson 1922: 61. — Olsoufieff 1924: 22. — Pessôa 1934: 282. — Balthasar 1939: 238. — Pessôa \& Lane 1941: 470. — Islas 1942: 303. - Blackwelder 1944-1957: 209. - Halffter 1952: 79; 1955: 79. - Roze 1955: 45. — Martínez 1959: 97. — Halffter \& Matthews 1966: 258. — Vulcano \& Pereira 1967: 566. — Edmonds 1972: 740; 1979: 99; 1994: 8; 2003: 11; 2004: 119; 2006: 31. — Edmonds \& Halffter 1978: 321. — Howden \& Young 1981: 12. — Arnaud 1982: 114; 2001: 2; 2002a: 2; 2002b: 13; 2018: 3. — Halffter \& Edmonds 1982: 136. — Medina \& Lopera 2000: 303. — Vítolo 2000: 595. — Medina et al. 2001: 140. — Ratcliffe 2002: 16. — Philips et al. 2004: 50. — Price 2005: 197; 2007: 1; 2009: 137. — Hamel-Leigue et al. 2006: 17; 2009: 64. — Krajcik 2006: 148. — Gillett et al. 2010: 2 — Vaz-de-Mello et al. 2011: 25. — Edmonds \& Zídek 2012: 1. —Solís \& Kohlmann 2012: 7. - Cancino-López et al. 2014: 140. — Figueroa et al. 2014: 133. — Manjarres-H \& Molano-R 2015: 246. — Pacheco \& Vaz-de-Mello 2015: 1. — Halffter \& Morrone 2017: 19. — Lizardo et al. 2017: 271. — Moctezuma \& Halffter 2017: 47. — Moctezuma et al. 2017: 114; 2019: 249; 2020: 3. - Chamorro et al. 2018: 75; 2019: 210. — Kohlmann et al. 2018: 67. — Gillett \& Toussaint 2020: 2 .

Lonchophorus - Brullé 1837: 302 (as synonym of Phanaeus). - Agassiz 1846: 620. - Lacordaire 1856: 100 (as synonym of Phanaeus). - Gemminger \& Harold 1869: 1016 (as synonym of Phanaeus). - Nevinson 1892: 1 (as synonym of Phanaeus). — Gillet 1911: 81 (as synonym of Phanaeus). — Lucas 1920: 381 (as synonym of Phanaeus). — Olsoufieff 1924: 140 (as synonym of Phanaeus). - Blackwelder 1944-1957: 209 (as synonym of Phanaeus). — Martínez 1959: 97 (as synonym of Phanaeus). — Edmonds 1972: 826 (as synonym of Phanaeus); 1994: 46 (as synonym of Phanaeus). - Ratcliffe 2002: 16 (as synonym of Phanaeus). — Krajcik 2006: 148 (as synonym of Phanaeus). - Solís \& Kohlmann 2012: 7 (as synonym of Phanaeus). - Figueroa et al. 2014: 133 (as synonym of Phanaeus). — Chamorro et al. 2019: 210 (as synonym of Phanaeus).

Onthurgus - Edmonds 1972: 827 (as synonym of Phanaeus); 1994: 46 (as synonym of Phanaeus). Ratcliffe 2002: 16 (as synonym of Phanaeus). — Krajcik 2006: 148 (as synonym of Phanaeus). Solís \& Kohlmann 2012: 7 (as synonym of Phanaeus). — Figueroa et al. 2014: 133 (as synonym of Phanaeus). - Chamorro et al. 2019: 210 (as synonym of Phanaeus).

Palaeocopris - Edmonds 1972: 855; 1994: 46 (as synonym of Phanaeus). — Miller et al. 1981: 1 (as synonym of Phanaeus). — Ratcliffe 2002: 16 (as synonym of Phanaeus). — Solís \& Kohlmann 2012: 7 (as synonym of Phanaeus). — Chamorro et al. 2019: 210 (as synonym of Phanaeus).

Phaneus - Krajcik 2006: 148 (as synonym of Phanaeus).

Phanaeus arletteae Arnaud, 2018

Figs 17, 18A, 19A

Phanaeus (Notiophanaeus) arletteae Arnaud, 2018: 4.

Phanaeus blanchardi ab. viridicollis (unavailable infrasubspecific name) - Olsoufieff 1924: 149. Edmonds 1994: 443. - Arnaud 2002b: 98. - Edmonds \& Zídek 2012: 13 (as an unavailable infrasubspecific name referable to $P$. pyrois).

Phanaeus (Phanaeus) blanchardi ab. viridicollis - Martínez \& Pereira 1967: 68 (as synonym of P. funereus) (unavailable infrasubspecific name).

Phanaeus (Notiophanaeus) viridicollis - Arnaud 2002b: 98-99 (as a new combination for P. blanchardi ab. viridicollis) (unavailable infrasubspecific name). —Edmonds \& Zídek 2012: 13 (as an unavailable infrasubspecific name referable to $P$. pyrois).

Phanaeus viridicollis - Krajcik 2006: 153. - Edmonds \& Zídek 2012: 1, 6 (as an unavailable infrasubspecific name referable to $P$. pyrois). 
Non Phanaeus pyrois (error) - Moctezuma \& Halffter 2017: 55 (in part). - Moctezuma et al. 2017: 114, 130 (in part).

Phanaeus (Notiophanaeus) arletteae - Chamorro et al. 2018: 97; 2019: 213, pl. 46a.

Phanaeus arletteae - Kohlmann et al. 2018: 83, 88.

\section{Type material}

Holotype (revised from photograph from the original description)

ECUADOR • 3 , Arnaud 2018: 4, pl. 1, fig. a; Guayas, Kilometric point 18 Balzar-Quevedo Road; CPFA.

\section{Type locality}

Ecuador, Guayas, Kilometric point 18 Balzar-Quevedo Road.

\section{Distribution}

Pacific slope of the Andes, south-central Ecuador (Fig. 17).

\section{Remarks}

The genital morphology of this species remains unknown. We were not able to personally revise specimens of Phanaeus arletteae. Nevertheless, the external morphology of the holotype and a female paratype were illustrated by Arnaud (2018). We consider that the diagnostic characters provided by Arnaud (2018) are adequate to separate this species from closely related taxa. The commentaries of previous authors confirmed the validity of this species (Martínez \& Pereira 1967; Edmonds 1994; Arnaud 2002b; Edmonds \& Zídek 2012). Particularly, the morphology of the pronotum of the female is unique within the $P$. endymion species group.

Phanaeus bravoensis Moctezuma, Sánchez-Huerta \& Halffter, 2017

Figs 1A, 15, 18B, 19B

Phanaeus bravoensis Moctezuma et al., 2017: 115.

Phanaeus bravoensis - Kohlmann et al. 2018: 69. — Moctezuma et al. 2019: 253, fig. 5.

\section{Type material}

\section{Holotype}

MEXCIO • $\widehat{~}$, Moctezuma et al. 2017: 118, figs 6-8 (revised); Guerrero, Chilpancingo de los Bravo; IEXA.

\section{Type locality}

Mexico, Guerrero, Chilpancingo de los Bravo.

\section{Distribution}

Mexico, Sierra Madre del sur, central Guerrero (Fig. 15).

\section{Remarks}

This species was recently described by Moctezuma et al. (2017). To the original description we add that the elytral striae are impressed basally as distinct fossae; right lobe of endophallite copulatrix is more developed than left lobe; right lobe of endophallite copulatrix obtusely triangular, arched superiorly; left lobe of endophallite copulatrix lobed, strongly reduced; central ridge more developed than central 
column (Fig. 1A). For the female, the trituberculate cephalic carina with nearly aligned, similar sized, conical tubercles; frons punctures scarce, almost effaced; pronotal surface distinctly punctate; pronotal process trituberculate with a posterior concavity; all pronotal tubercles rounded, with middle tubercle slightly more developed and projected frontally than lateral tubercles; posterior pronotal midline distinctly impressed.

\section{Phanaeus chiapanecus sp. nov. urn:1sid:zoobank.org:act:55933BD6-8A56-49CB-B1B4-3AB7C1A235BE}

Figs 1B, 2A, 3, 15, 18C, 19C

\section{Diagnosis}

Phanaeus chiapanecus sp. nov. is a large and robust species which frequently attains $18.5-20 \mathrm{~mm}$ in length. This new species is diagnosed by the following character combination: Major male dark metallic blue-green or green dorsally (Fig. 3); keel absent in the middle of anterior pronotal margin (Fig. 2A); posterolateral angles of pronotum widened, elongate, slightly projected posteriorly (Fig. 3A); elytral striae thick, impressed basally as distinct fossae, with deeply impressed punctation; interstriae black, with completely or partially roughened surface (Fig. 3); endophallite copulatrix as Fig. 1B. Major female with pronotal process lacking concavities; pronotal tubercles nearly aligned, with middle tubercle more developed than lateral tubercles; posterior pronotal midline completely effaced (Fig. 3B).

\section{Etymology}

The specific epithet of the new species refers to Chiapas, where the type series was collected.

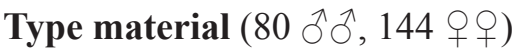

\section{Holotype}

MEXICO - ${ }^{7}$; Chiapas, "Loc. Vicente Guerrero, Mun. San Fernando. 20/05/2018. Selva Baja Caducifolia. Col. A. Díaz. Pit-Fall calamar. $16^{\circ} 51^{\prime} 10^{\prime \prime}$ N. $93^{\circ} 13^{\prime 2} 2^{\prime \prime W} .984$ msnm”; TAMU.

\section{Paratypes}

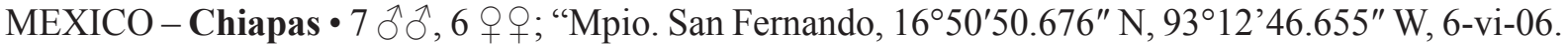

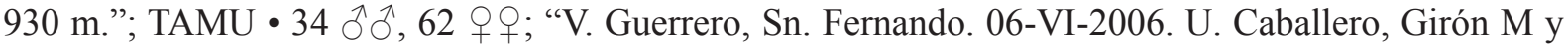
Miss-Barrera Col."; GHC • $3 \widehat{\partial} \widehat{\partial}, 5$ 우; same collection data as for preceding; TAMU • $19 \hat{\jmath} \widehat{\partial}, 23$ 우; same collection data as for preceding; VMC $\bullet 2$ ते, 2 우; same collection data as for preceding;

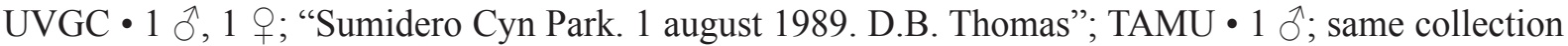

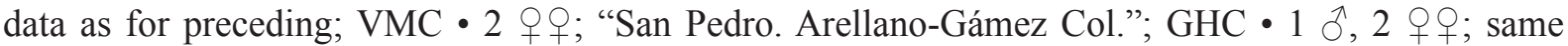

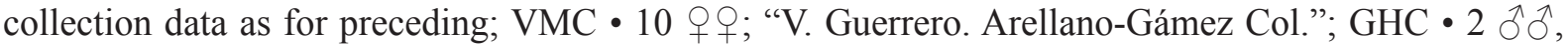
1 q; same collection data as for preceding; VMC • 9 q $\circ$; "Vicente Guerrero, La Antena. Molina A.

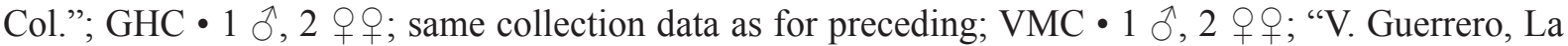

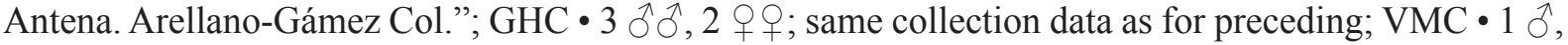
1 q; “Km. 40. Carr. Tuxtla-San Cristóbal (El Escopetazo). 2-VIII-70. V.M. Sánchez. col. Bosque-pino encino arcilloso. Cebo-pescado"; GHC • 1 § , 5 우; "V. Guerrero, S. Fernando. UC, MG, Irma”; GHC •

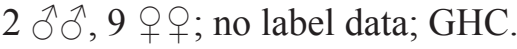

\section{Type locality}

Mexico, Chiapas, San Fernando, Vicente Guerrero.

\section{Description}

Major male (holotype)

Length $18.8 \mathrm{~mm}$. 

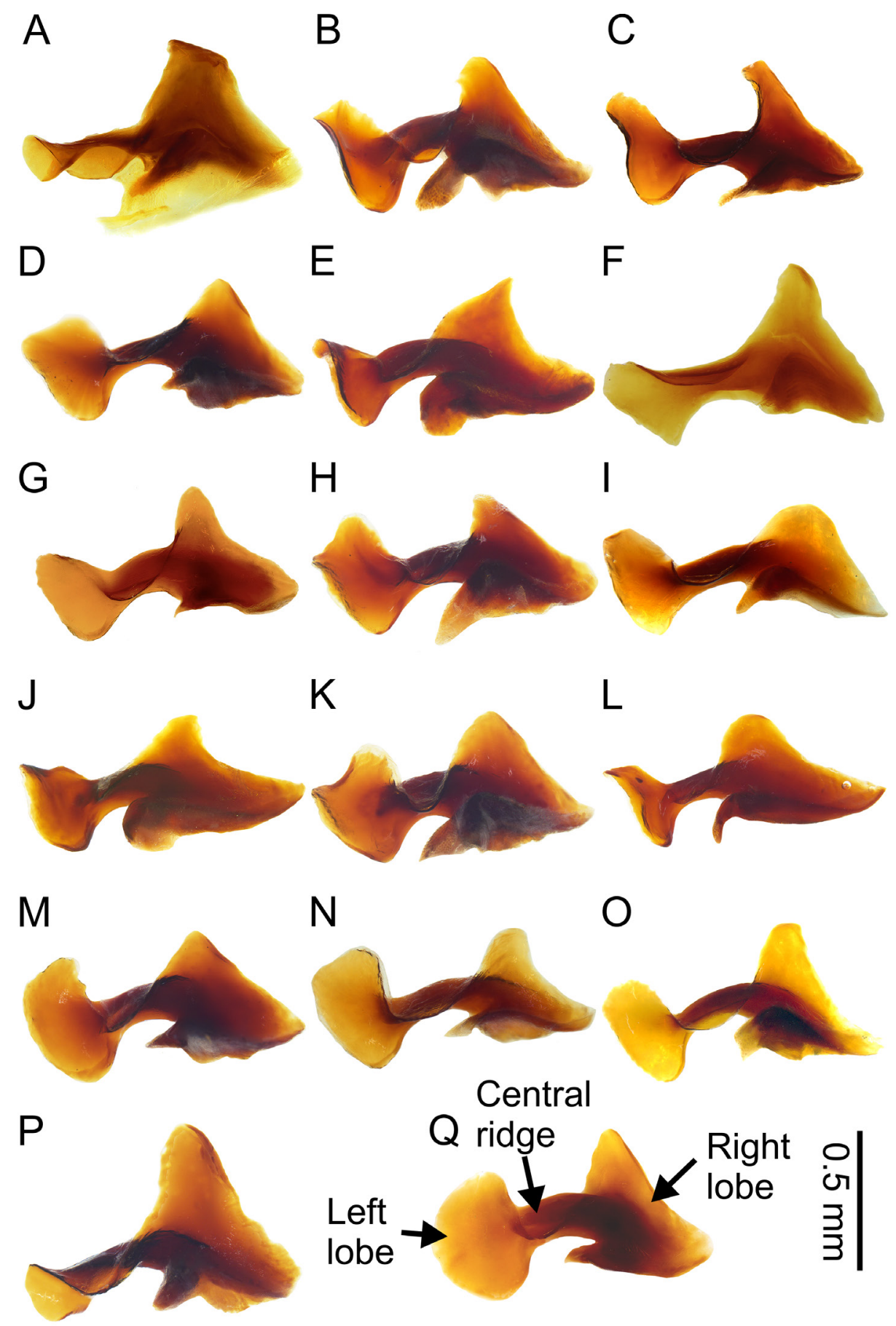

\section{Central}

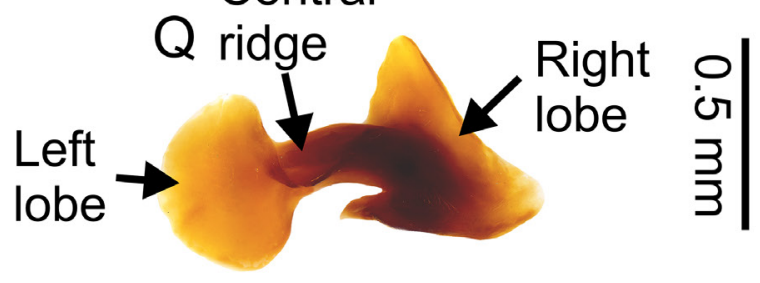

Fig. 1. Endophallite copulatrix of the Phanaeus endymion species group (except for P. arletteae Arnaud, 2018). A. Phanaeus bravoensis Moctezuma, Sánchez-Huerta \& Halffter, 2017 (IEXA). B. Phanaeus chiapanecus sp. nov. (TAMU). C. Phanaeus edmondsi Moctezuma, Deloya \& Halffter, 2019 (IEXA). D. Phanaeus endymion Harold, 1863 (VMC). E. Phanaeus funereus Balthasar, 1939 stat. rev. (VMC). F. Phanaeus halffterorum Edmonds, 1979 (TAMU). G. Phanaeus huichol Moctezuma, SánchezHuerta \& Halffter, 2017 (IEXA). H. Phanaeus jackenioi sp. nov. (UVGC). I. Phanaeus malyi Arnaud, 2002 (VMC). J. Phanaeus olsoufieffi Balthasar, 1939 stat. rev. (VMC). K. Phanaeus pacificus sp. nov. (UVGC). L. Phanaeus panamensis sp. nov. (TAMU). M. Phanaeus porioni Arnaud, 2001 stat. rev. (VMC). N. Phanaeus pyrois Bates, 1887 (VMC). O. Phanaeus rzedowskii sp. nov. (TAMU). P. Phanaeus zapotecus Edmonds, 2006 (VMC). Q. Phanaeus zoque Moctezuma \& Halffter, 2017 (IEXA). 

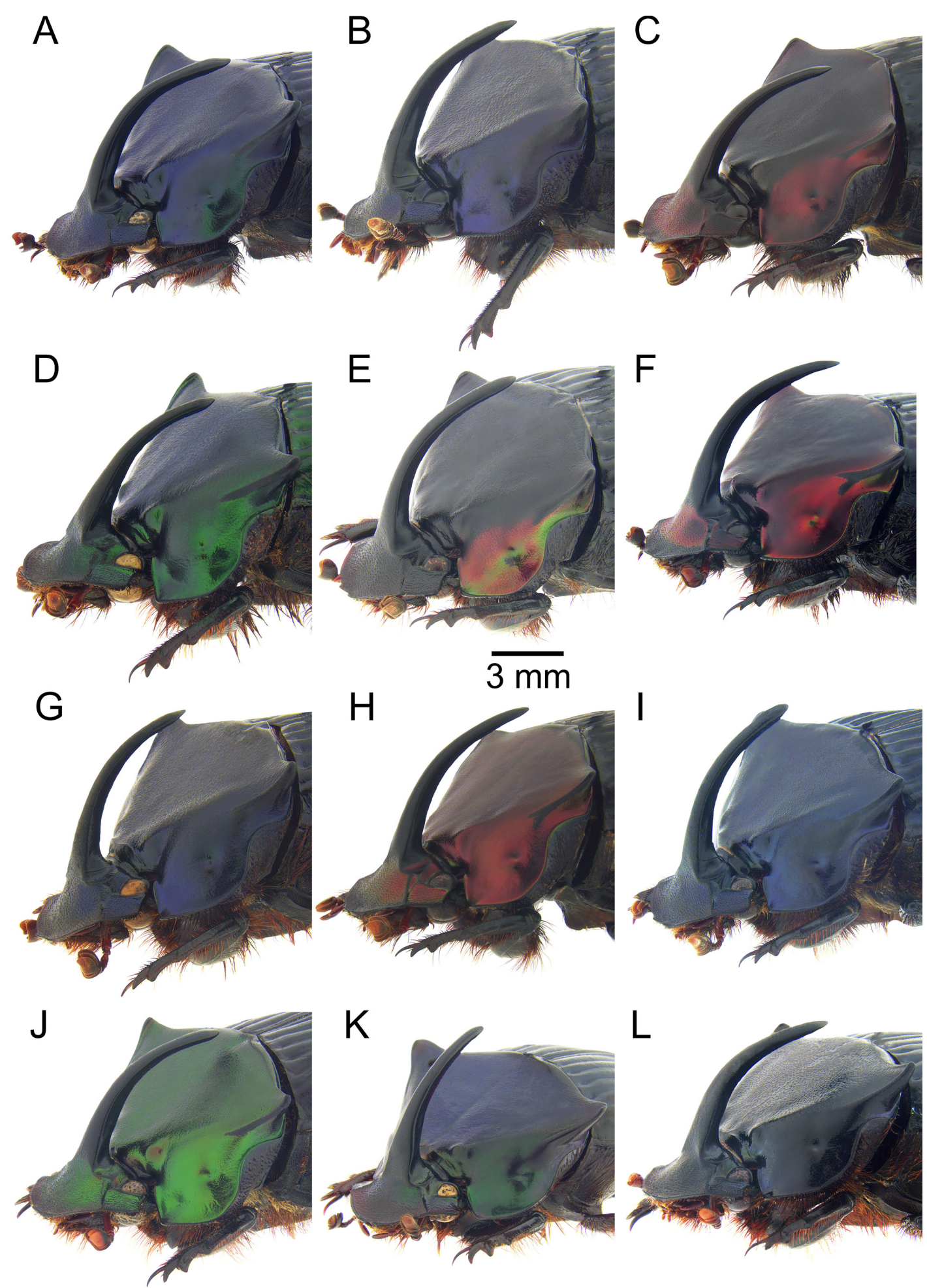

$\mathrm{L}$

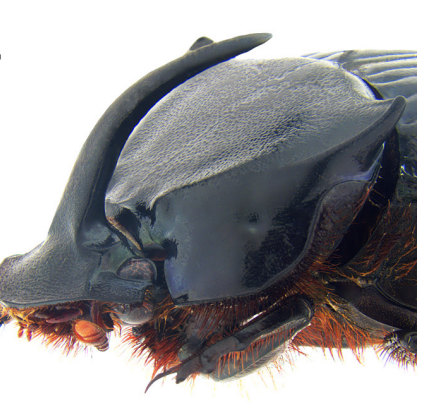

Fig. 2. Lateral view of males within the Phanaeus endymion species group. A. Phanaeus chiapanecus sp. nov. (TAMU). B. Phanaeus endymion Harold, 1863 (VMC). C. Phanaeus funereus Balthasar, 1939 stat. rev. (VMC). D. Phanaeus jackenioi sp. nov. (UVGC). E. Phanaeus malyi Arnaud, 2002 (VMC). F. Phanaeus olsoufieffi Balthasar, 1939 stat. rev. (VMC). G. Phanaeus pacificus sp. nov. (UVGC). H. Phanaeus panamensis sp. nov. (TAMU). I. Phanaeus porioni Arnaud, 2001 stat. rev. (VMC). J. Phanaeus pyrois Bates, 1887, green morph (VMC). K. Phanaeus rzedowskii sp. nov. (TAMU). L. Phanaeus zapotecus Edmonds, 2006 (VMC). 
HEAD. Clypeus bidentate, black on anterior margin, dark metallic blue-green posteriorly, with roughened sculpture. Genae dark metallic blue-green, with roughened sculpture. Front black, with dark metallic blue-green on portions adjacent to cephalic horn. Cephalic horn black, curved posteriorly over pronotum (Figs 2A, 3A).

Pronotum. Uniformly dark blue, becoming black on lateral margins of posterolateral angles and on posterior margin of disc. Keel absent in the middle of anterior pronotal margin. Disc triangular, flat, with two distinctly developed tubercles on anterior portion. Pronotal triangle with lightly granulate sculpture, scabriculous, impunctate. Sides with smooth sculpture, scabriculous, with superficially impressed punctures. Lateral lines of pronotal triangle straight. Posterolateral angles widened, elongate, slightly projected posteriorly, slightly upturned apically. Lateral fossae distinctly impressed. Basal fossae obtusely oval, deeply impressed. Posterior margin distinctly punctate (Figs 2A, 3A).

ELYTRA. Striae thick, dark blue-green, scabriculous, impressed basally as distinct fossae, with deeply impressed punctation. Interstriae black, with completely or partially roughened surface, scabriculous, with superficially impressed punctation. Sutural margin without apical tooth (Fig. 3A).

Protibiae. Quadridentate with apical spine.

TERgite VIII. Dark green, scabriculous; with rough, distinctly impressed punctures. Basal margin with setae variable in size.

GeNITALIA. Right and left lobes of endophallite copulatrix similar in size. Right lobe obtusely triangular in shape; with acute, upturned apical portion. Left lobe bent posteriorly, with superior portion obtusely rectangular. Central ridge more developed than central column (Fig. 1B).

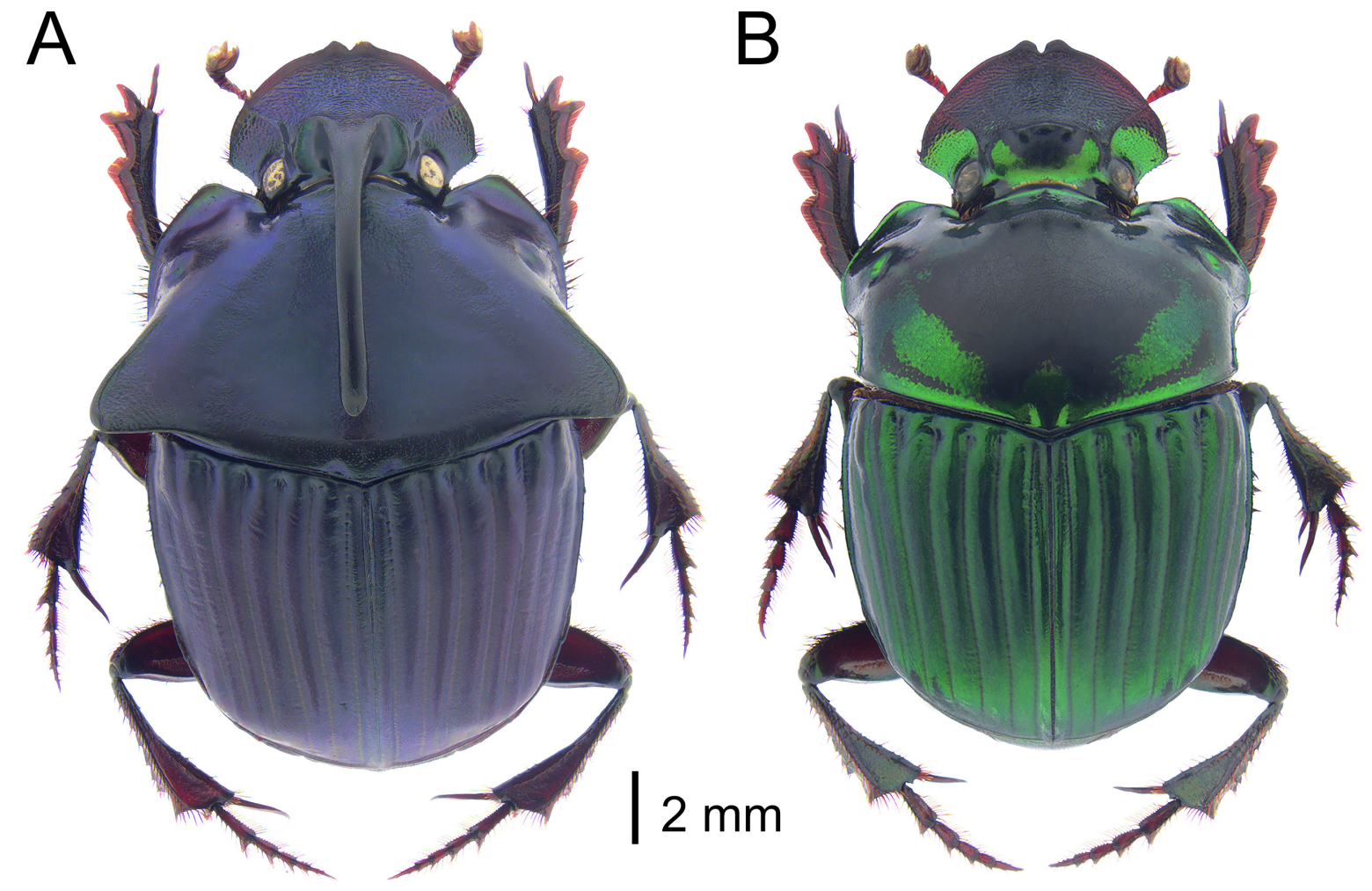

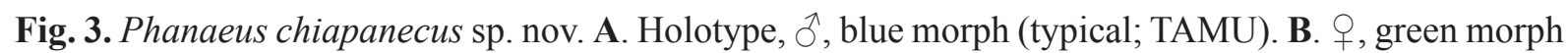
(TAMU). 


\section{Minor male}

Like the major male, except for the reduction of the secondary sexual characters (i.e., cephalic horn, pronotal triangle and tubercles, and pronotal posterolateral angles).

\section{Female}

Similar to the male, except for the head showing a cephalic trituberculate carina with carinate middle tubercle, slightly more projected frontally, less raised than conical lateral tubercles; frons almost impunctate; pronotal sculpture completely smooth with scarce, superficially impressed punctures; pronotal disc black on central portion, metallic dark blue-green on sides and posterior portion; pronotal process trituberculate lacking concavities; pronotal tubercles nearly aligned, with middle tubercle more developed than lateral tubercles; posterior pronotal midline completely effaced (Fig. 3B).

\section{Variation}

Mean length $16.9 \mathrm{~mm}(12.4-20.6 \mathrm{~mm})$. The typical colour morphs are dark metallic blue (Fig. 3A) or dark metallic green (Fig. 3B), but a rare specimen shows metallic yellow-green sheen on head, pronotum and elytra. The elytral interstriae are dark metallic blue, or rarely dark metallic green.

\section{Distribution}

Mexico, Central highlands of Chiapas (Fig. 15).

\section{Remarks}

This species was referred to as P. pyrois by Arellano et al. (2008) and GBIF Secretariat (2019b), and as $P$. endymion by Morón et al. (1986), Edmonds (1994), Arellano et al. (2013), Lizardo et al. (2017), Moctezuma \& Halffter (2017) and Sánchez-Hernández et al. (2020). Nevertheless, the distribution areas of the aforementioned species do not overlap with the distribution of $P$. chiapanecus sp. nov., which is distinctly differentiated by its morphology.

Phanaeus edmondsi Moctezuma, Deloya \& Halffter, 2019

Figs 1C, 15, 18D, 19D

Phanaeus edmondsi Moctezuma et al., 2019: 251.

\section{Type material}

\section{Holotype}

MEXICO • ^, Moctezuma et al. 2019: 251, figs 1-3 (revised); Oaxaca, Candelaria Loxicha, Portillo del Rayo; CNIN.

\section{Type locality}

Mexico, Oaxaca, Candelaria Loxicha, Portillo del Rayo.

\section{Distribution}

Pacific slope of the Sierra Madre del Sur, southern Oaxaca (Fig. 15).

\section{Remarks}

This species was recently described and illustrated (Moctezuma et al. 2019). To the original description of the female we add: cephalic trituberculate carina of head with carinate central tubercle, anteriorly more projected not as raised as lateral, conical tubercles; frons with superficially impressed punctures; pronotal sculpture completely smooth with superficially impressed punctures; pronotal process trituberculate 
lacking concavities; central pronotal tubercle slightly more developed and projected anteriorly than lateral tubercles; posterior pronotal midline completely effaced.

Phanaeus endymion Harold, 1863

Figs 1D, 2B, 4, 18E, 19E, 20

Phanaeus endymion Harold, 1863: 163.

Phanaeus endymion - Gemminger \& Harold 1869: 1017. — Bates 1887: 58. — Nevinson 1892: 3, 10; 1892b: 34. — Olsoufieff 1924: 37, 91, 150, 164, pl. VI, fig. 7. — Islas 1942: 314, 318-319, 336, pl. 1 (in part). - Blackwelder 1944-1957: 209 (in part). - Halffter \& Matthews 1966: 40, 68, 70, 74 (in part). — Edmonds 1972: 830, figs 218-220 (in part); 1979: 99, 102-103, figs 4, 9-10 (in part); 2006: 31-32, 35-36, figs 2, 4, 6-7 (in part). - Morón 1979: 381, 423, 434, 449, fig. 20b; 1985: 63, 88, 91, 97, 107, fig. 20. — Arnaud 1982: 114; 2001: 4 (in part). — Palacios-Ríos et al. 1990: 59. — Estrada \& Coates-Estrada 1991: 465. — Halffter et al. 1992: 139, 149, 153-155; 1995: 162, 164-166, 173. — Estrada et al. 1993: 48-49; 1998: 586-587, 589. — Deloya \& Morón 1998: 19. — López-Guerrero \& Halffter 2000: 241 (in part). — Montes de Oca 2001: 118, 123 _ — Avendaño-Mendoza et al. 2005: 810, 813, 815, 817. — Price 2005: 197 (in part); 2007: 17, figs 33, 52-54 (in part); 2009: 139, figs 2-4 (in part). — Krajcik 2006: 150 (in part). — Gillett 2008: 5. — Navarrete \& Halffter 2008: 2880, 2888, 2893, 2895. — Halffter \& Halffter 2009: 6, 8. — Díaz et al. 2010: 6-8. - Inward et al. 2011: 1677, fig. 2, appendix s2. — Edmonds \& Zídek 2012: 1, 5-6 (in part). - Barragán et al. 2011: fig. 1. — Delgado et al. 2012b: 209. — Alvarado et al. 2014: tables s1-2; 2019: 175; 2020: 5. — Cancino-López et al. 2014: 137 (in part). — Bourg et al. 2016: 493494. - Huerta et al. 2016: 16 (in part). — Sánchez-de-Jesús et al. 2016: table A4. — Halffter 2017: fig. 7 (in part). — Lizardo et al. 2017: 273-275, 292-293, fig. 12 (in part). — Moctezuma \& Halffter 2017: 47, 51-52, 55 figs 17-23 (in part). - Moctezuma et al. 2017: 114, 123, 131-132 (in part); 2019: 251-254, fig. 5 (in part). — Kohlmann et al. 2018: 79, 83, 88 (in part). — Sánchez-Hernández et al. 2018: 149-150; 2020: 229 (in part). - Santos-Heredia et al. 2018: appendix 1. — Gillett \& Toussaint 2020: 11, fig. 3 (in part). - Salomão et al. 2020: 3-4, 8-9 (in part).

Phanaeus (Notiophanaeus) endymion - Edmonds 1994: 2, 8-9, 12, 19, 36, 39, 41-46, 54, 74, 101, figs 17, 209, 215-216, 221 (in part); 2003: 65 (in part). — Arnaud 2002b: 94-95 (in part). — Delgado et al. 2012a: 327. — Edmonds \& Zídek 2012: 3, 13, figs 132-133, 136, 140, 143, 152-155 (in part). Halffter \& Morrone 2017: 21. — Lizardo et al. 2017: 272 (in part). — Capello \& Halffter 2019: 113, figs 41a-b.

Phanaeus (Phanaeus) endymion - Edmonds 2003: 63, Fig. 2.20 (in part).

\section{Diagnosis}

Highly variable species, diagnosed by the following character combination: major male dark blue (Fig. 4A), dark metallic blue-green or dark metallic green dorsally (Fig. 4B); sometimes with carinate, distinctly developed keel in the middle of anterior pronotal margin (Fig. 2B); posterolateral angles of pronotum short, widened, sometimes lightly projected posteriorly (Figs 4A-B); elytral striae impressed basally as distinct fossae, with distinctly impressed to effaced punctures (Fig. 4); endophallite copulatrix as in Fig. 1D. Major female with pronotal process concave posteriorly; middle pronotal tubercle more developed, dentiform or rounded, always more projected frontally than lateral tubercles; lateral tubercles obtusely rounded or carinate; posterior pronotal midline superficially impressed to completely effaced (Fig. 4C). 


\section{Type material}

Lectotype (studied from photographs)

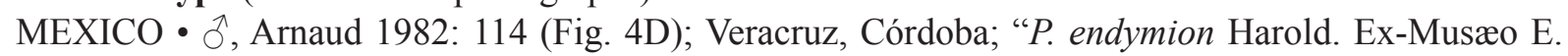
Harold. Muséum Paris 1952 Coll. R. Oberthur. MNHN EC10553”; MNHN.

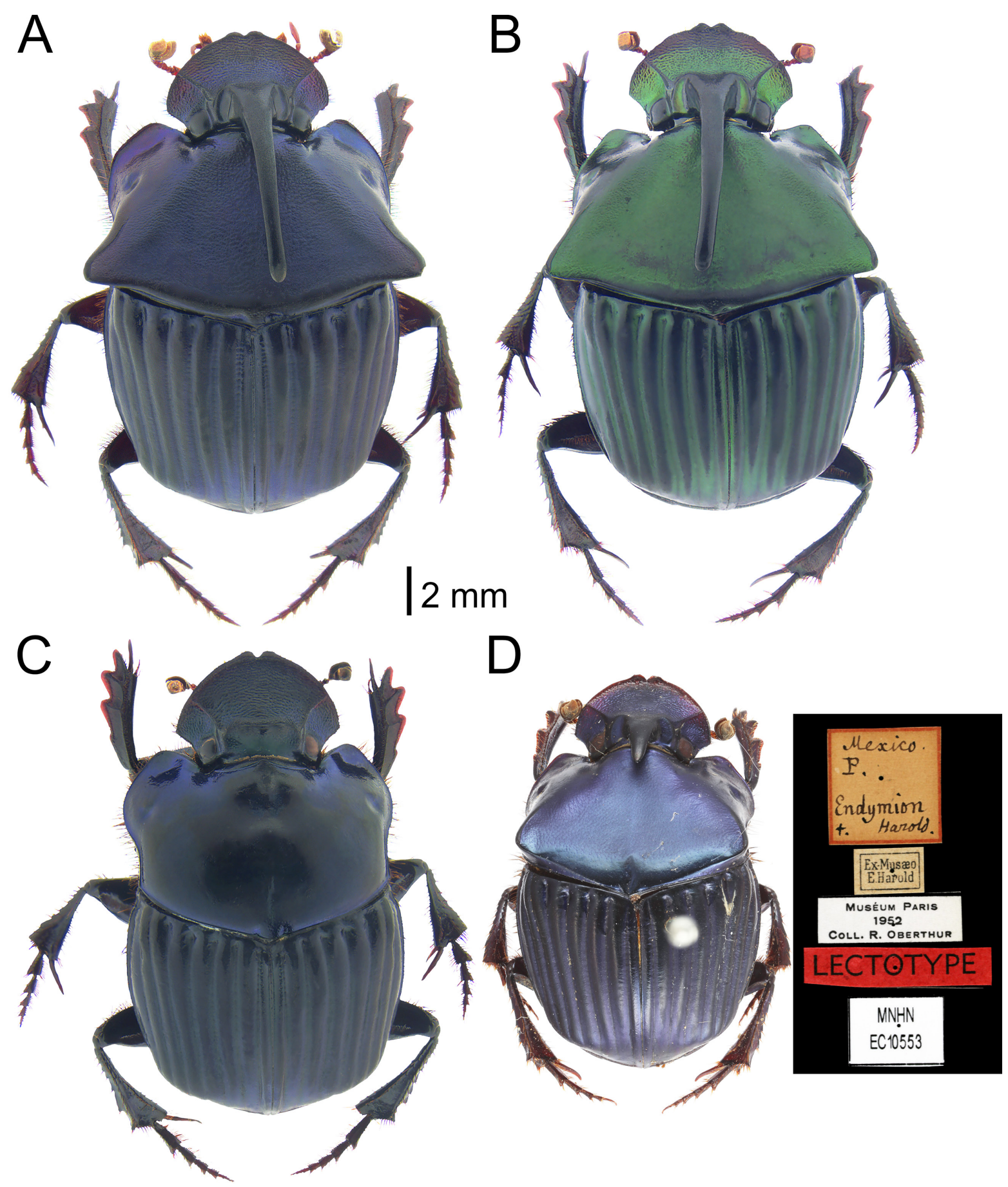

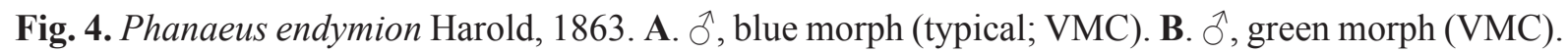
C. + , blue morph (typical; VMC). D. Lectotype, § (by Christophe Rivier, Muséum national d'histoire naturelle, Paris, France) (MNHN). 
Paralectotype (studied from photographs)

MEXICO • 1 क; Veracruz; "Ex-Musæo E. Harold. Museum Paris ex Coll. R. Oberthur. MNHN EC10554"; MNHN.

\section{Non-type material revised $(212 \curvearrowright \hat{\jmath}, 247 \stackrel{+}{0})$}

BELIZE - Cayo • 1 `’; “Chiquibul Forest Reserve, Las Cuevas Research Station. $16^{\circ} 44^{\prime} \mathrm{N}, 88^{\circ} 59^{\prime} \mathrm{W}$. June 2006. BMNH \{E\} 2006-141. C. Gillett \& J. Kitson"; TAMU • 1 क; "San Ignacio, Chiquibul Fst Res. Las Cuevas Res. Station. $16^{\circ} 43^{\prime} \mathrm{N}, 88^{\circ} 59^{\prime} \mathrm{W}, 02-17 . i v .2004$. Deciduous forest, baited pitfall. coll. R. Paterson. Deciduous tropical forest. Baited pitfall trap. Cattle dung. Sub-site: Grano de Oro. Selective

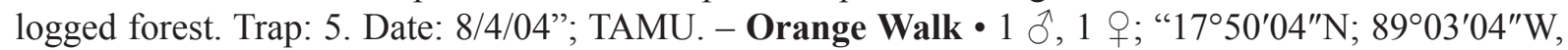
Rio Bravo Cons Area, La Milpa, Arqueolog. Site, (\#12), 11-17.VII.1996, P. Kovarik ex. Flight intercept trap."; JLSHC • 1 ठ̊̄; "Rio. Bravo Cons, Area, env. La Milpa ruins, 19-20.VII.1996, P.W. Kovarik, collector. La Milpa transect site \#12, flight intercept trap"; JLSHC. - Stann creek - 1 ơ; " $16^{\circ} 48^{\prime} 40^{\prime \prime} \mathrm{N}$, $88^{\circ} 30^{\prime} 34^{\prime \prime}$ W. Cockscomb Basin Wildlife Sanctuary, Outlier Trail nr. Campground. 3.VIII.2006. P. W. Kovarik, coll., FIT"; JLSHC.

GUATEMALA - Alta Verapaz • 1 §’; "Sanahu. Fca. El Volcán. 14.VII.1988. J.P. Mauger \& K. Meyer. 1200 msnm"; UVGC • 1 đ̊?; "Senahú, Fca. El Volcán. 850 msnm. 19-VII-88. Col: F. Herrera"; VMC • 2 우; “Colector Carlos García. Heces de humano. Sta. Lucia Lachua. Cobán. 16-09-00”; UVGC• 1 O’, 1 q ; "Santa Lucia Lachua. Junio 2001, heces humanas. Col. A. Higueros"; UVGC • 1 9 ; same collection data as for preceding; VMC. - Huehuetenango - 1 \%; "Barillas, aldea Malpais. 1263m, N.1584733, W091.22285. Bosque nuboso. 21 VI 2009. Col. F. Camposeco, UV+M-Arc400w."; VMC • 1 ऊ’; "Octubre 1992. Colector J. Monzón"; VMC. - Izabal • 1 đ̃'; "Livingston. Biotopo Chocón. Machacas. 28-29 V 2002. Heces de vaca. Guamil. Col. E.B. Cano."; UVGC • 1 đ̇; "Livingston. Biotopo Chocón. Machacas. 17-23 VI 1997. col. C.Avendaño. B. tropical húmedo inundable"; TAMU • 1 \&; "Río Dulce, Fca. Talismán. 9 III 1997. G. Pereira"; TAMU • 1 P; "Cerro San Gil, Río Carbonera. 1390 msnm. III-2 IV 2007. Col. R. Granajo"; UVGC • 1 क; "El Estor, Cuiscoyol, GCN. 27 III 2010. J.Rivers"; UVGC • 1 đૈ, 2 우; “Cerro San Gill, Carboneras, estación biol 400 msnm. 08 IX 1999. Bosque tropical. Trampa

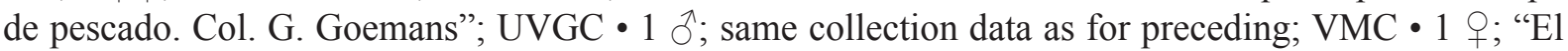
Estor, CGN sector 215 con tala. 24 III 2010. J.Rivers"; UVGC • 2 q ; ; same collection data as for preceding; VMC • 1 ठ̊; "El Estor, CGN sector pino guiscoyol. 1-3 IX 2009. J.Rivers"; VMC. - Petén • 1 †; "La Libertad, Bethel. 18 IX 1995. M.Jolon. En trampeo ratones había caído. Oryxomis melesotis"; UVGC • 1 q; "La Libertad, Bethel. 14 XII 1995. Trampa de roedores. M.Jolon.”; UVGC・ 1 §̊; "San Miguel la Palotada. 15-V-1999. Col. Mjolon"; UVGC • 1 \%; same collection data as for preceding; VMC • 1 q; "San Miguel la Palotada. 16-III-1999. Col. Mjolon"; UVGC • 1 đ̃; "Dolores. 17-VIII-

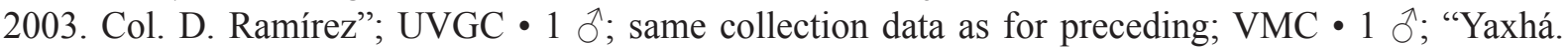
Area nucleo. 2 XII 1996. X. Leiva"; TAMU • 1 đ̃; "Flores, El Remate. Biot. Cerro Cahuí. 7.VIII.1996. E.Cano"; UVGC.

MEXICO - Chiapas • 1 ; ; “Templo de las Inscripciones, Palenque, 22-VI-1993, Borde-copro-24 hrs.

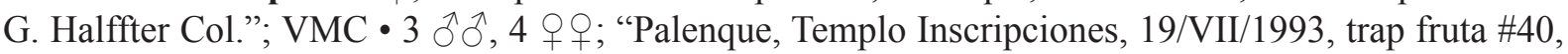

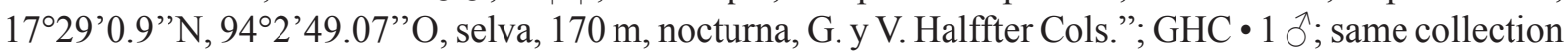
data as for preceding; VMC • 1 + ; "Casa arqueólogos, Palenque, 22-VI-1993, Selva B-copro-24 hrs. G. Halffter Col."; GHC • 1 ô; "Casa Arqueólogos, Palenque, 20-VI-1993, Selva-copro A-24 hrs.

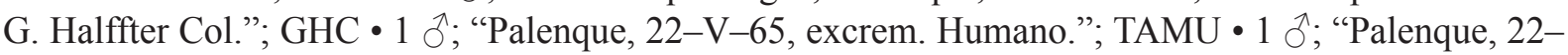

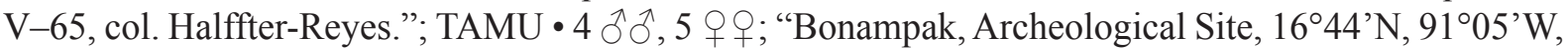
300 m, 24-26-IX-77, forest, human feces, W. D. Edmonds, col.”; TAMU • 1 ô, 1 q; same collection data as for preceding; VMC $\bullet 1$ + ; "Bonampak, Archeological Site, $16^{\circ} 44^{\prime} \mathrm{N}, 91^{\circ} 05^{\prime} \mathrm{W}, 300 \mathrm{~m}$, I-IX-77, B. Kohlmann, col.”; TAMU • 1 ○’; “Bonampak, Archeological Site, $16^{\circ} 44^{\prime} \mathrm{N}, 91^{\circ} 05^{\prime} \mathrm{W}, 300 \mathrm{~m}, 24-\mathrm{IX}-$

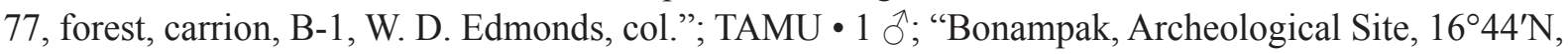




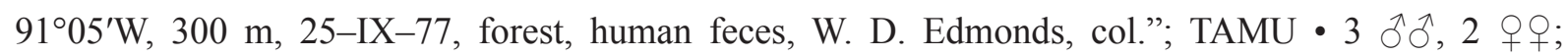
"Bonampak, Archeological Site, $16^{\circ} 44^{\prime} \mathrm{N}, 91^{\circ} 05^{\prime} \mathrm{W}, 300 \mathrm{~m}, 8-\mathrm{IX}-77$, forest, human feces, W. D. Edmonds, col."; TAMU • 1 `े; "Bonampak Archeological Site, $16^{\circ} 44^{\prime} \mathrm{N}, 91^{\circ} 05^{\prime} \mathrm{W}, 8-\mathrm{IX}-77$,

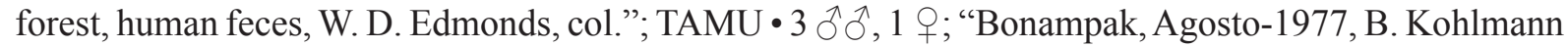
Col."; VMC • 1 क; "Laguna Miramar, 14-15-X-1976, G. y V. Halffter, col.”; GHC • 1 क; "Chansayab, Lacanja, 24-I-77, P. Reyes C., Col.”; GHC • 1 क; "Lacanja, Chansayab, 26.IV.77, G. Aguirre, E. Frey, col."; VMC • 1 đ̊; "Lacanja, Chansayab, 6-II-77, S. Gallina, Col."; VMC • 1 o; "Lacanjá-Chansayab, 300 m, 6-VIII-1977, camino a La Selva, M. Lamotte \& B. Kohlmann col.”; TAMU • 1 ơ; same collection data as for preceding; VMC • 1 §ै; "Lacanja, VIII-1977, \#11, Selva alta, Bert Kohlmann, Col.”; GHC • 1 ô, 3 우; "Boca de Chajul, alt 110 m, 3-II-1984, M.A. Morón, C. Fragoso, F.J. Villalobos, cols.”; IEXA • 1 đ’; “4800’, 6.6 mi. W. El Bosque, VIII.25-29.1973, Cl. For. A. Newton 542”; TAMU Oaxaca • 1 क; "Km Valle Nal. 550m 17/18-V-94, C. Deloya, R. Arce, coprotrampa"; IEXA • 1 万”; “2000', 6 mi S Valle Nac. VII.71, A. Newton 299"; TAMU • 1 O̊, 1 q; “Concepción Pápalo, 1800 m, 13-VII-97, hongos, G. Nogueira"; IEXA • 1 §̃; "La Chinantla, Sierra Norte. Selva mediana. 29-IIX2010. 400 m. Pit-fall exc. hum. T-2. Alvarado, F. Col."; FESC • 1 đ̊; "Disto. De Yautepec, Juquila Mixes, VIII.1973, W. Miller"; VMC • 1 o; "La Nueva Esperanza, I-IX-1980, C. Huerta-G. Quintero-E. Rivera Cols.”; GHC・102 đ̂̉, 123 우; "Santa María y San Miguel Chimalapa, Benito Juárez/Santa María Chimalapa/San Antonio/San Francisco La Paz. Victor Moctezuma col."; VMC. Quintana Roo • 1 ô, 1 q; "X-Can, VI-77, E. Welling, col."; TAMU • 1 क; "Puerto Morelos, 3-IX1984, G. y V. Halffter, cols. Selva baja-media, cebo excremento humano, noche/día"; GHC • 1 ठ; "Carrillo Puerto, 25-26-XII-82, G. Halffter y V. Halffter, Col."; VMC • 1 q; "Carrillo Puerto, Septiembre 1984, A. Martínez, col.”; GHC. - Veracruz • 1 ō; “Córdoba, 13-VII-36, E. W. Torrens niger d'Ols.”; GHC・ 2 đō, 6 + 9 ; “Córdoba, Guadalupe del Barreal, alt. 940 m, E. Santos, Col. NTP-1-C. 2-VIII-92. Julio"; IEXA • 4 ภำ, 5 우우 "Córdoba, Guadalupe del Barreal, alt. 940 m, E. Santos, Col. NTP-1-C. 2-VII-92. Junio"; IEXA • 1 §, 1 क; "Córdoba, Gpe. Barreal, alt. 940 m, E. Santos, Col. NTP-3. X-91”; IEXA・1 ô; "Córdoba, Gpe. Barreal, alt. 940 m, Cafetal, E. Santos, Col. NTP-3. VIII-91"; IEXA • 1 o";

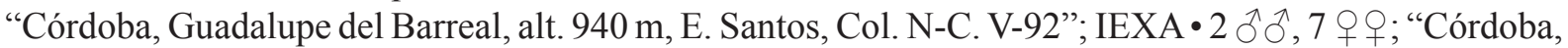
Guadalupe del Barreal, VIII-91, cafetal, NTP-80, E. Santos, Col."; IEXA • 1 ô, 1 q; "Córdoba, Guadalupe del Barreal, VII-91, cafetal NTP-80, E. Santos, Col.”; IEXA • 1 q; "Córdoba, Guadalupe del

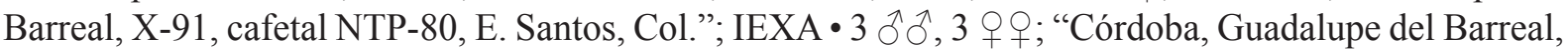
IX-91, cafetal NTP-80, E. Santos, Col."; IEXA • 1 đ; " "Cordoba, 18-20/July/62, Terry W. Taylor.";

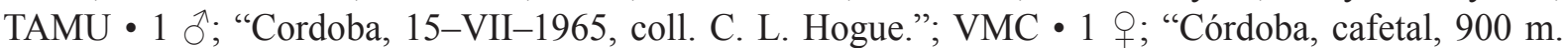

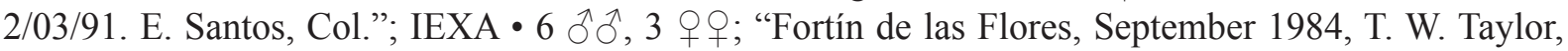

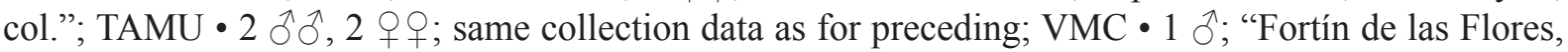
14-VII-1973, R. R. Shelling and T. W. Taylor, colls."; TAMU • 1 ơ; "Presidio, VII-48, A. Ramírez"; VMC • 1 ơ; "Presidio, VII-52, G. H"; GHC • 1 q; "Presidio, V-47, A. Ramírez"; VMC• 1 ơ; "Presidio,

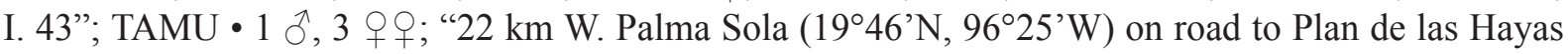
( \pm 800 m), 30-31/VIII/1976, W. D. Edmonds and Bert Kohlmann cols. Code: K22-HF-F. Collected in baited pitfall trap: $\mathrm{HF}=$ human feces; $\mathrm{SF}=$ swine feces; $\mathrm{CC}=$ carrion. Habitat: $\mathrm{F}=$ remains of forest; $\mathrm{P}=$ pasture (clearing).”; TAMU • 3 우; “1 km al E de Jalcomulco, NTP-80, alt. 500 m. 6-XI-91. Luis Quiroz, col.”; IEXA • 1 ô, 1 q; "Jalcomulco, Cerro Brujo, 06-VIII-15. 400 m. CT3 Bosque, selva baja, Álvaro Hernández Rivera Col.”; FESC • 1 ơ; "Xalapa, 30/Julio/80, Col. E. Aranda D.”; IEXA • 1 ô, 1 ○; "Xalapa, Chiltoyac, 20/VI/15, 1000 m. NT2 Selva baja, Álvaro Hernández Rivera Col." ; FESC • 1 o ; "Xalapa, Chiltoyac, 1000 m. NT1 Bosque, Álvaro Hernández Rivera Col.”; FESC • 2 q ; ; "Xalapa, Chiltoyac, 20/VI/15, 1000 m. CT2 Potrero, Álvaro Hernández Rivera Col.”; FESC • 1 ô, 1 q. "Xalapa,

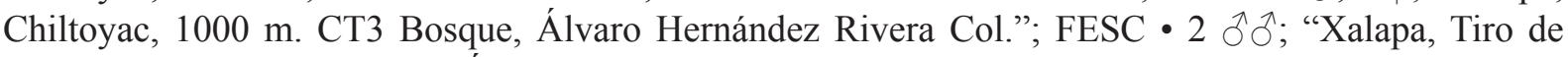
Hayas, 1200 m. NT2 Bosque, Álvaro Hernández Rivera Col.”; FESC • 1 \&; "Sumidero, Tiro de Hayas. 16 sep - 5 de oct 1989. L. Arellano col. Bosque mesófilo perturbado. 1366 m. NTP 80"; GHC • 1 đ̄; "N.C 600"; GHC • 2 우 ; "Veracruz, 1962-63, leg. Epping."; GHC・ 1 ภ; "Escoloa, 15 july 1972, Terry W. Taylor, coll.”; TAMU • 3 우; “Ixtaxoquitlán, Cerro Chicahuaztla. 1540 m. VI.87. Col. L. Delgado"; 


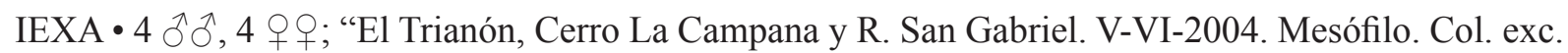
hum. Escobar y Pineda Cols."; FESC • $3 \widehat{\partial} \widehat{\partial}, 1$ क ; same collection data as for preceding; IEXA • 1 \& ; "Tatahuicapan de Juárez, López Arias, Magallanes. 21-VI-2002. F. Escobar S. Col. Fragmentos de selva alta. Trampa \#8. Cebo-exc. humano"; FESC • 1 q; "Tatahuicapan de Juárez, El Mirador, Magallanes.

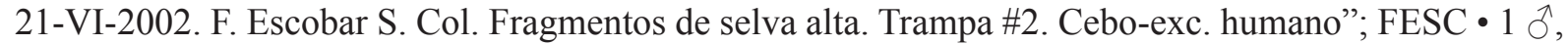
4 우; "Catemaco, Pipiapan, Parque de la Flora y Fauna Silvestre Tropical, 600 m., VIII-1991, Selva Med. Per. F. Capistran Col. NTP”; IEXA • 1 q; "Catemaco, Est. Biol. Trop. Los Tuxtlas, Bosq. Trop. Perennifolio, 17 VIII 90, M. F. Favila y A. Díaz. Cols."; VMC • 1 đ̃; "Los Tuxtlas. Estación Biológica UNAM. Selva alta. 01-VII-2010. 200 m. Pit-fall exc. hum. T-12. Alvarado, F. Col."; FESC • 3 + ; ; "Los Tuxtlas, 21/VIII/87, G. Halffter y V. Halffter, Cols."; GHC • 1 § ; "Guadalupe Victoria. PIA. Tm10.”; FESC • 1 o; "T6m."; FESC • 1 ô, 1 o ; "Km 7.5, Carr. El Castillo, 15-oct-1994, L. Arellano y R. Sánchez cols. Alt. 1100 m, Bosque de pino/café, trampa necropermanente.”; TAMU • 1 \&; "Apazapan,

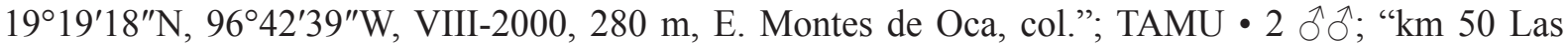
Choapas-Río Playa, 30-XII-1977, carroña, selva media, Col. B. Kohlmann"; TAMU • 1 \%; "Dos Amates

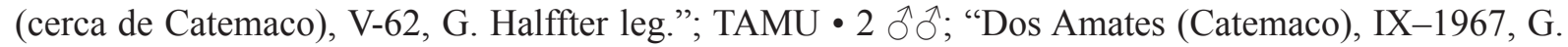

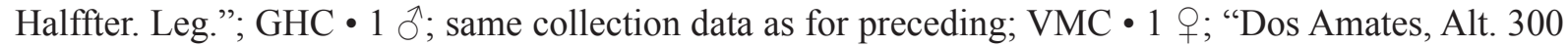
m. 29-XI-67. Col. P. Reyes C. Selva tropical perturbada. Cebo excremento humano. Noche-Día."; VMC • 1 क; "Estación de Biología Tropical Los Tuxtlas, VIII-1984, A. Martínez, Col.”; GHC • 1 \%; “20 km al E de Sontecomapan, 11-IV-69, H. Cabrera, col.”; GHC. - Yucatán • 1 §, 1 \%; "Municipio de Tizimín, 18-VII-13, 200 m. Bosque (Zapotal). Colecta trampa copro pit-fall \#6. Alvarado, F. Col.”; FESC • 3 ô ภิ, 2 우; "Municipio de Tizimín, -VII-13, $200 \mathrm{~m}$. Bosque (Espita). Colecta trampa copro pit-fall \#3. Alvarado, F. Col.”; FESC • 2 $\widehat{\jmath}, 4$ 우; "Municipio de Tizimín, 28-VII-13, 200 m. Bosque (Santa Marta). Colecta trampa copro pit-fall \#25. Alvarado F. Col.”; FESC.

\section{Type locality}

Mexico, Veracruz, Córdoba.

\section{Redescription}

\section{Major male}

HeAD. Clypeus bidentate, black on anterior margin, dark metallic blue-green or green on posterior portion, rough sculpture. Genae dark metallic blue-green or green with rough sculpture. Front black, with dark metallic blue-green or green on portions adjacent to cephalic horn. Cephalic horn black, curved posteriorly over pronotum (Figs 2B, 4A-B).

Pronotum. Uniformly dark blue, dark metallic blue-green or dark metallic green, becoming black beneath posterolateral angles. Carinate, distinctly developed keel in the middle of anterior pronotal margin, or keel completely effaced. Disc triangular, flat, with two distinctly developed tubercles on anterior portion. Triangle with lightly granulate or nearly smooth sculpture, scabriculous, impunctate. Sides with almost smooth sculpture, scabriculous, with superficially impressed punctures. Lateral lines of triangle straight. Posterolateral angles short, widened, sometimes lightly projected posteriorly. Lateral fossae distinctly impressed. Basal fossae obtusely oval, superficially to deeply impressed. Posterior margin with superficially to deeply impressed punctures (Figs 2B, 4A-B).

ElytRA. Striae fine, dark metallic blue-green, or dark metallic green, scabriculous, impressed basally as distinct fossae, with distinctly impressed to effaced punctures. If punctures distinctly impressed, each forming a distinct fossa, giving a completely roughened surface to first and second striae. If punctures effaced, interstriae completely smooth. Interstriae black, with smooth surface, scabriculous, superficially impressed to effaced punctation. Sutural margin without apical tooth (Figs 4A-B).

Protibiae. Quadridentate with apical spine. 
TERGITE VIII. Dark metallic blue-green, or dark metallic green, scabriculous; with rough, distinctly impressed punctures. Basal margin with setae variable in size.

Genitalia. Right lobe of endophallite copulatrix more developed than left lobe. Right lobe obtusely triangular in shape. Left lobe obtusely lobed inferiorly, obtusely triangular superiorly. Central ridge less developed than central column (Fig. 1D).

\section{Minor male}

Like the major male, except for the reduction of secondary sexual characters (i.e., cephalic horn, pronotal triangle and tubercles, and pronotal posterolateral angles).

\section{Female}

Similar to the male, except for the head showing a cephalic trituberculate carina with similar in size, nearly aligned, conical tubercles; frons with distinctly to superficially impressed punctures; pronotal sculpture completely smooth, with superficially impressed punctures; shining black, variable in size area on central portion of pronotal disc; pronotal process trituberculate, with posterior concavity; middle pronotal tubercle more developed, dentiform or rounded, always more frontally projected than lateral tubercles; lateral tubercles obtusely rounded or carinate; posterior pronotal midline superficially impressed to completely effaced (Fig. 4C).

\section{Variation}

Mean length $17.9 \mathrm{~mm}(13.9-20 \mathrm{~mm})$. The typical colour morph is dark metallic blue-green (Figs 4A, C), but a less frequent dark metallic green morph (Fig. 4B) is also found, while scarce specimens are completely bright metallic green. The interstriae are completely dark metallic blue-green or dark metallic green in some specimens. The rarest specimens from Chiapas and Veracruz show a bright metallic yellow or red sheen on head, pronotum and elytra. Variation in the interstrial punctation is observed in the whole distribution area of $P$. endymion. The size of the right and left lobes of the endophallite copulatrix is not homogeneous.

\section{Distribution}

From Veracruz and the Yucatan Peninsula to Belize and northern Guatemala (Fig. 15).

\section{Remarks}

The lectotype (a minor male), a female paralectotype and several specimens $(n=42)$ from the type locality cited by Harold (1863) were used for the redescription of $P$. endymion, that was complemented with specimens from its whole distribution area. As a consequence, the high intraspecific variation of $P$. endymion is adequately represented herein. Although $P$. endymion is a polymorphic species, closely related species are confidently separated by differences in the pronotal morphology of males and females, elytral interstriae, and genital morphology.

Phanaeus funereus Balthasar, 1939 stat. rev.

Figs 1E, 2C, 5, 17, 18F, 19F

Phanaeus (s. str.) funereus Balthasar, 1939: 241.

Phanaeus funereus - Edmonds 1972: 830; 1994: 3, 9, 45-46 (as synonym of P. pyrois). — Howden \& Young 1981: 137 (in part). — Arnaud 1982: 116 (as synonym of P. blanchardi); 2002b: 97 (as subspecies of $P$. pyrois). - Krajcik 2006: 152 (as synonym of P. pyrois). — Solís \& Kohlmann 2012: 8 (as synonym of $P$. pyrois). — Edmonds \& Zídek 2012: 3, 5, 13 (as synonym of $P$. pyrois). Chamorro et al. 2019: 220-221 (as synonym of $P$. pyrois).

Phanaeus (Phanaeus) funereus - Martínez \& Pereira 1967: 53, 68 (as synonym of P. olsoufieffi).

Phanaeus (Notiophanaeus) pyrois funereus - Arnaud 2002b: 97-98 (as subspecies of P. pyrois). Chamorro et al. 2019: 220 (as synonym of P. pyrois). 
Phanaeus pyrois funereus - Kohlmann et al. 2018: 79, 93 (as subspecies of $P$. pyrois).

Phanaeus (s. str.) funereus - Chamorro et al. 2019: 220-221 (as synonym of P. pyrois).

Non Phanaeus pyrois (error) - Medina et al. 2001: 140 (in part). — Moctezuma \& Halffter 2017: 55 (in part). — Moctezuma et al. 2017: 114, 130 (in part). — Chamorro et al. 2018: 98.

\section{Diagnosis}

Easily diagnosed species by the dull black colour with dull red sheen dorsally; and striae not strongly impressed basally (Fig. 5). Additionally, the major male with a keel absent in the middle of anterior pronotal margin (Figs 2C, 5A); endophallite copulatrix as Fig. 1E. The major female with the pronotal process lacking concavity; middle pronotal tubercle more developed, slightly projected frontally than lateral tubercles; all pronotal tubercles rounded; and posterior pronotal midline completely effaced (Fig. 5B).

Type material (studied from photographs, $1 \precsim$ )

\section{Holotype}

ECUADOR - §̂, Balthasar 1939: 242 (Fig. 5C); “P. funereus (illegible data). Dr. V. Balthasar det./Mus. Nat. Pragae Inv. 26347/ex coll. V. Balthasar National Museum Prague, Czech Republic/ Pucay F.O.I0.6.05. / $\hat{\jmath} / \mathrm{H}$. Blut determ. Phanaeus blanchardi Olsouf./Fesche det. Phanaeus pyrois Bts./TYPUS"; NMPC.

\section{Non-type material revised $(5 \hat{\jmath}, 7 \stackrel{+}{0})$}

COLOMBIA - Chocó• 1 đ̊; "Quibdó. La Troje - Sept. 972. Coll. Martínez”; VMC.

ECUADOR - Esmeraldas • 1 ơ; “Tsejpí Ex.Pitfall heces humanas 17/02/01 I. Yépez”; VMC・1 O’; "Tsejpí. Ex.Pitfall heces humanas. 18/02/01. I. Yépez"; TAMU • 1 + ; "Colón del Ónzole. Ex.Pitfall carroña. 04/05/01 I. Yépez"; TAMU.- Guayas • 1 ठ̊; "Pucay (Bucay). F. Ohs. 14.7.05.”; GHC. - Los Ríos • 1 ô, 1 क; "Quevedo, Pichilingue (75 m) V-76. A. Martínez col."; TAMU • 2 q $q$; "Quevedo, Pichilingue. V-76. A. Martínez, leg."; GHC • 1 q; same collection data as for preceding; VMC. Manabí • 1 o; " 300 m, 90kmWSW Sto. Domingo. 73 km NE Chone. 6-9.vi.76. S. Peck. 3 for. dung traps3-5"; IEXA. - Pichincha • 1 क; "Quito. III.915"; TAMU.

\section{Type locality}

Ecuador, Pucay (probably Bucay).

\section{Redescription}

\section{Major male}

HeAD. Clypeus bidentate, dull black on anterior margin, dull red on posterior portion, roughened sculpture. Genae dull black, with dull red sheen, rough sculpture. Front dull black. Cephalic horn black, curved posteriorly over pronotum (Figs 2C, 5A).

Pronotum. Keel absent in the middle of anterior pronotal margin. Disc triangular, flat; with two elongate, weakly developed tubercles on anterior portion. Triangle dull black, scabriculous, with almost effaced punctures, smooth sculpture. Sides dull black-red; scabriculous, with smooth sculpture, almost effaced punctures. Lateral lines of triangle straight. Posterolateral angles short, slightly widened. Lateral fossae distinctly impressed. Basal fossae absent or almost effaced. Posterior margin with almost effaced punctures (Figs 2C, 5A).

ELYTRA. Striae fine, smooth, dull black, scabriculous, not strongly impressed basally; with dull green or blue-green sheen, almost effaced punctures. Interstriae dull black, scabriculous, with smooth surface, almost effaced to effaced punctures. Sutural margin without apical tooth (Fig. 5A). 
Protibiae. Quadridentate with apical spine.

TERGITE VIII. Dull black, with dark red to dark brown sheen; scabriculous sculpture; rough, distinctly impressed punctures. Basal margin with setae variable in size.

Genitalia. Right lobe of endophallite copulatrix larger in size than left lobe. Right lobe obtusely triangular in shape, with superior portion projected frontally. Left lobe lobed inferiorly, bent superiorly. Central ridge less developed than central column (Fig. 1E).

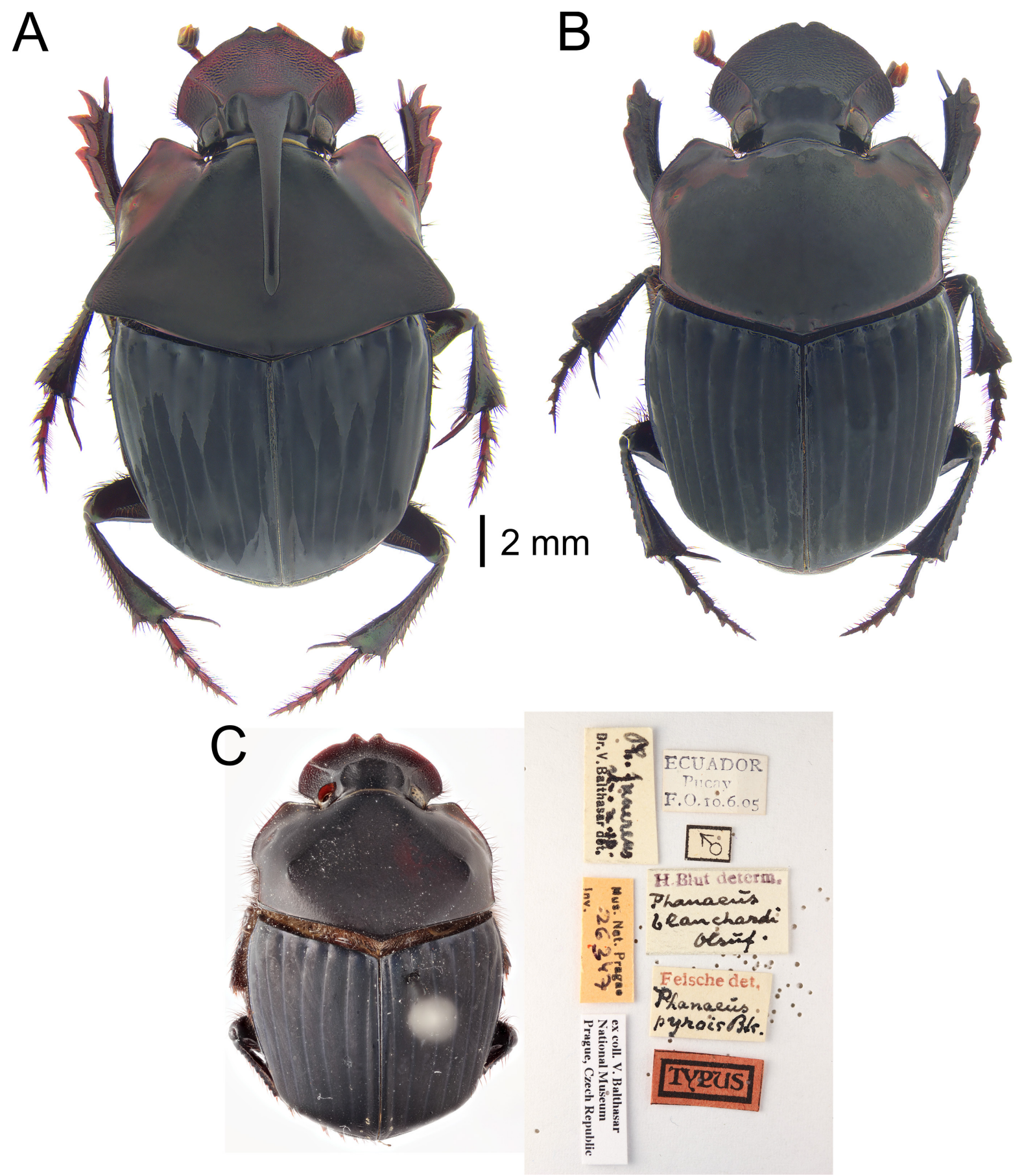

Fig. 5. Phanaeus funereus Balthasar, 1939 stat. rev. A. $\hat{\jmath}$ (TAMU). B. $q$ (TAMU). C. Holotype, $\hat{\jmath}$ (by Jiří Hájek, Národní Muzeum, Prague, Czech Republic) (NMPC). 


\section{Minor male}

Like the major male, except for the attenuation of the secondary sexual characters (i.e., cephalic horn, pronotal triangle and tubercles, and pronotal posterolateral angles; Fig. 5C).

\section{Female}

Similar to the male, except for the head showing a cephalic trituberculate carina, with similar in size, conical tubercles; middle tubercle more frontally projected than lateral tubercles; frons with almost effaced punctures; pronotal sculpture completely smooth, impunctate or with almost effaced punctures; pronotum almost completely dull black, dark metallic red laterally and posteriorly; pronotal process trituberculate lacking concavity; middle pronotal tubercle more developed, slightly projected frontally than lateral tubercles; all tubercles rounded; posterior pronotal midline completely effaced (Fig. 5B).

\section{Variation}

Mean length $19.3 \mathrm{~mm}(16-21.9 \mathrm{~mm})$. The male specimen from Colombia has acute posterolateral pronotal angles that are posteriorly projected.

\section{Distribution}

Pacific slope of the Andes, north-central Ecuador and Colombia (Fig. 17). The Colombian specimen represents the first record of $P$. funereus from Colombia.

\section{Remarks}

Phanaeus funereus was considered by previous authors as a synonym of P. pyrois (Martínez \& Pereira 1967; Edmonds 1994; Edmonds \& Zídek 2012; Solís \& Kohlmann 2012; Chamorro et al. 2019). Nevertheless, a diagnosis and a key to separate both species are provided by us. As a consequence, full species status is confidently assigned to P. funereus. The lectotype (a minor male) and some specimens from Ecuador $(\mathrm{n}=12)$ were used for the redescription of $P$. funereus. The only specimen studied from Colombia differed in the posterolateral angles of pronotum, but not in colour pattern, pronotal and elytral sculpturing, or genital morphology.

Phanaeus halffterorum Edmonds, 1979

Figs 1F, 15, 18G, 19G

Phanaeus halffterorum Edmonds, 1978: 321 (nomen nudum).

Phanaeus halffterorum Edmonds, 1979: 99, 102-105, figs 1-3, 6-8 (in part).

Phanaeus halffterorum - Halffter \& Edmonds 1982: 88-89 (in part). — Anduaga \& Halffter 1991: 157 (in part). - Delgado-Castillo et al. 1993: 125 (in part). - Deloya et al. 1993: 21, 39 (in part); 2014: 77 (in part). - Anduaga 2000: 125, 130 (in part). — López-Guerrero \& Halffter 2000: 241 (in part). — Arnaud 2002b: 96 (in part). — Price 2005: 197 (in part); 2007: 17, figs 52-54. — Edmonds 2006: 31-32, 36, fig. 7 (in part). — Ceballos et al. 2009: 397. — Edmonds \& Zídek 2012: 5 (in part). - Krajcik 2006: 150. — Moctezuma \& Halffter 2017: 52, 54-55, fig. 23 (in part). Moctezuma et al. 2017: 113-115, 118-119, 122, 130-132, figs 1-5; 2019: 253, fig. 5. — Lizardo et al. 2017: 273, 275, 292, fig.13 (in part). — Kohlmann et al. 2018: 69, 81, 88-89. — Gillett \& Toussaint 2020: 2.

Phanaeus (Notiophanaeus) halffterorum - Edmonds 1994: 2, 8-9, 19, 39, 41, 43-44, 101, figs 211, 213, 217-218, 221 (in part); 2003: 61, 65 (in part). — Arnaud 2002b: 95 (in part). — Edmonds \& Zídek 2012: 3, 12, figs 134-135, 137, 143-147 (in part). — Lizardo et al. 2017: 272 (in part). — Kohlmann et al. 2018: 80. — Zaragoza-Caballero et al. 2019: 43. 


\section{Type material}

Holotype (not studied)

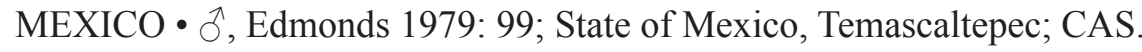

Paratypes revised $\left(6 \hat{\partial} \partial^{\lambda}, 2 q q\right)$

MEXICO - State of Mexico • 1 đ̊; " "5 km E Temascaltepec, Real de Arriba (2200 m), 10-VII-1976, fungus, oak-pine forest, W. D. Edmonds, P. Reyes, B. Kohlmann cols.”; IEXA • 1 q; same collection data as for preceding; TAMU $\bullet 1 \hat{\partial}, 1$; ; same collection data as for preceding; VMC • $2 \hat{\jmath}$; " $8 \mathrm{~km} \mathrm{~W}$ Temascaltepec, $2360 \mathrm{~m}, 11-\mathrm{VII}-76$, fungus in pine-oak forest, W. D. Edmonds, P. Reyes, B. Kohlmann cols."; TAMU • 1 § ; same collection data as for preceding; VMC • 1 §; "Real de Arriba, VII-1932, 6300 ft, México D. F., Hinton coll., BM 1939-583"; TAMU.

\section{Type locality}

Mexico, State of Mexico, Temascaltepec.

\section{Distribution}

Central Trans-Mexican Volcanic Belt, State of Mexico and Morelos (Fig. 15).

\section{Remarks}

Mean length $17.4 \mathrm{~mm}$ (13.4-19.9 mm). The specimens from Morelos (Deloya et al. 1993) were not studied by us. This species was erroneously reported from Mexico City (Arnaud 2002b). This mistake is attributed to Hinton (1935), who recorded it from Real de Arriba, Mexico D.F. Real de Arriba is actually located in the State of Mexico. Despite the fact that Moctezuma et al. (2017) split $P$. halffterorum and $P$. bravoensis, the colouration pattern of $P$. halffterorum remains as indicated by Edmonds (1979), with bright metallic green or dark metallic blue specimens. In a review of the immature dung beetles of Scarabaeinae (Edmonds \& Halffter 1978), the name P. halffterorum Edmonds, 1978 was published. Nevertheless, this may be considered as a nomen nudum under Article 13 of the Code (ICZN 1999). Consequently, the same name was available later for the same or a different concept under Arts 21, 50; while P. halffterorum Edmonds 1979 must be considered the available authorship and date.

To the original description of the male we add that the right lobe of the endophallite copulatrix is more developed than the left lobe; the right lobe ois btusely triangular; the left lobe is obtusely rectangular; the central ridge lis ess developed than the central column (Fig. 1F). For the female can be added that the trituberculate cephalic carina has conical, nearly aligned tubercles; the middle tubercle is more raised than the lateral tubercles; the pronotal process is trituberculate, with a posterior concavity; all the tubercles are rounded; the middle tubercle is slightly more developed and projected frontally than the lateral tubercles; the pronotal midline is distinctly impressed, with superficially impressed punctures; the pronotal surface is smooth, with almost effaced punctures.

Phanaeus huichol Moctezuma, Sánchez-Huerta \& Halffter, 2017

Figs $1 \mathrm{G}, 15,18 \mathrm{H}, 19 \mathrm{H}$

Phanaeus huichol Moctezuma et al., 2017: 123.

Phanaeus huichol - Kohlmann et al. 2018: 69, 81, 83, 88. - Moctezuma et al. 2019: 252-253, fig. 5. Phanaeus (Notiophanaeus) huichol - Kohlmann et al. 2018: 81. 


\section{Type material}

\section{Holotype}

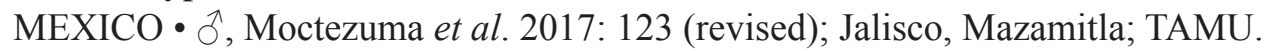

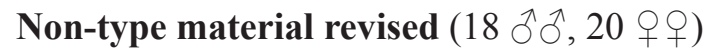

MEXICO - Jalisco • 1 ㅇ " "Sierra de Talpa (Los Venados CT). 12-15-VIII-2017. 1570 m. G. Nogueira

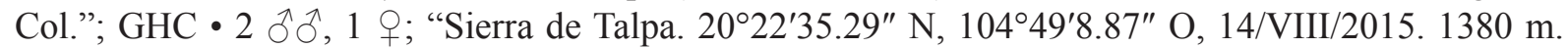

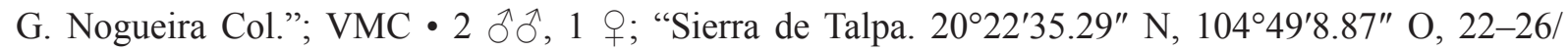

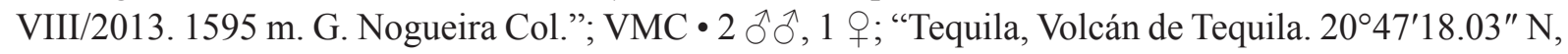

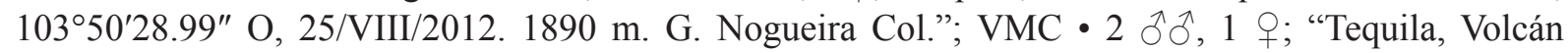
de Tequila. $20^{\circ} 47^{\prime} 18.03^{\prime \prime} \mathrm{N}, 103^{\circ} 50^{\prime} 28.99^{\prime \prime} \mathrm{O}, 24-27 / \mathrm{VIII} / 2012.1665$ m. (CT). G. Nogueira Col.";

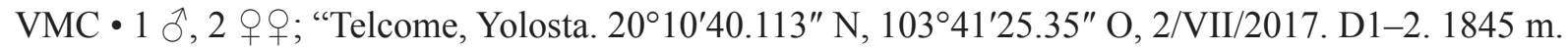

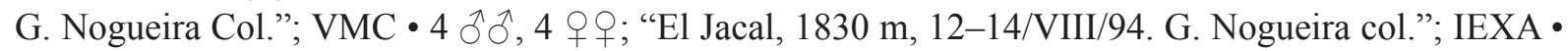

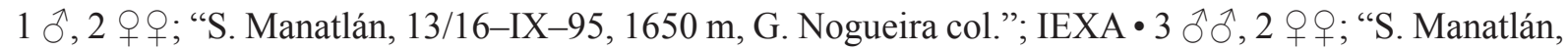
18/20-IX-1995, 1400 m, G. Nogueira col."; IEXA • 1 đ̂, 4 우; "S. Manatlán, 18/20-IX-1995, 1650 m, G. Nogueira col.” ; IEXA. - Michoacán • 1 q; "12 km S Uruapan, Cascada Tzararacua. 1450 m. 21-VIII-97 horse dung"; VMC.

\section{Type locality}

Mexico, Jalisco, Mazamitla.

\section{Distribution}

Sierra Madre Occidental; Jalisco, northern Michoacán, Nayarit and southern Sinaloa (Fig. 15). The first record of $P$. huichol from Michoacán is presented herein.

\section{Remarks}

The original description of $P$. huichol indicates that the colour pattern varies from dark metallic green, bright metallic green, to dark green with blue sheen. After revising additional specimens, a bright metallic green morph with red sheen was found by us. To the original description we add the elytral striae impressed basally as distinct fossae; and central ridge and column of endophallite copulatrix similar in size (Fig. 1G). For the female, the head showing a cephalic trituberculate carina with middle tubercle more frontally projected, carinate and less prominent than lateral tubercles; frons with almost effaced punctures; pronotal sculpture completely smooth, with almost effaced punctures; pronotal process trituberculate, with posterior concavity, followed posteriorly by reduced, rounded tubercle; middle tubercle dentiform or rounded, more developed and projected frontally than lateral tubercles; lateral tubercles rounded or carinate; posterior pronotal midline completely effaced.

Phanaeus jackenioi sp. nov. urn:1sid:zoobank.org:act:CF4B33E3-1245-4631-A019-2CAF43709603

Figs $1 \mathrm{H}, 2 \mathrm{D}, 6,15,18 \mathrm{I}, 19 \mathrm{I}$

\section{Diagnosis}

Easily diagnosed species by the bright metallic green colour; striae wide, roughened, impressed basally as distinct fossae, with distinctly impressed punctation; the major male with posterolateral angles of pronotum sharply acute, elongate, projected posterolaterally (Figs 2D, 6A); the major female with pronotal process without frontal concavity; rounded pronotal tubercles, nearly aligned, with middle tubercle more developed than lateral tubercles (Fig. 6B). 


\section{Etymology}

We are honoured to dedicate this new species to Jack Schuster and Enio Cano. They have significantly contributed to the knowledge of the Guatemalan scarab beetles, particularly of the family Passalidae.

Type material (11 $\hat{\jmath}, 5$ 우)

\section{Holotype}

GUATEMALA • ^̊; Guatemala; “10/XI/1978. Eugenia de Minondo”; UVGC.

\section{Paratypes}

GUATEMALA - Chimaltenango • 1 q; "Parramos, El Injertal. 13/IX/1978. Eugenia de Minondo";

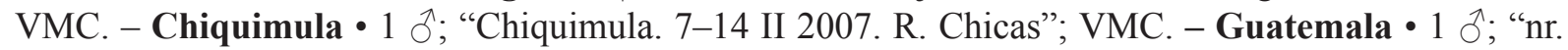
Barranca Sta. Catarina. Pinula, Z-14. 22 VI 1993. E. Póll leg. Luz incandescente"; VMC • 1 ठ̊; "Ciudad. 13 X 1982. S. Roesch"; TAMU • 1 O’; "Guatemala. 214 VIII 1984. J. Perez"; CNMN • 1 O; "Sta. Rosa z.16. Kanajuyú 2. 22.XI.2000. M.L.Muller"; UVGC. - Huehuetenango • 1 đ̇; "Nentón. Camino entre Nentón y San José Chaquial. 22 VII 1998. Bosque seco. E.B. Cano Heces de perro"; UVGC • 1 đ;; "Chivacabé. 31 X 1993. E. Cano"; UVGC • 1 ô; same collection data as for preceding; VMC • 1 ô; "La libertad, La Mesilla, finca El Bolsón. 24 IX 2011. Cafetal. Luz UV + HG. Col. M. Acevedo \& H. Enríquez."; TAMU • 1 ; same collection data as for preceding; UVGC • 1 + ; same collection data as for preceding; VMC. - Sacatepéquez • 1 ; "Bosque pasado. Comunidad Ruiz, km35 a Mixco Viejo via San Juan Sac. 29-X-1978. E. Duarte"; TAMU. - Zacapa • 1 ○’; "San Lorenzo, cerca de La Marmolera. 5 XII 2001. En heces de vaca. A. Higueros, leg. Bosque de pino, aprox. 1700msnm"; UVGC.

MEXICO - Chiapas • 1 đ̊; “'Santa Rosa, VIII-1962. G. Halffter leg.”; TAMU.

\section{Type locality}

Guatemala, Guatemala.

\section{Description}

Major male (holotype)

Length $17.1 \mathrm{~mm}$.

HEAD. Clypeus bidentate, black on anterior margin, bright metallic green on posterior portion, with roughened sculpture. Genae bright metallic green, with roughened sculpture. Front black, with dark metallic blue-green on portions adjacent to cephalic horn. Cephalic horn black, curved posteriorly over pronotum (Figs 2D, 6A).

Pronotum. Uniformly bright metallic green, becoming black on lateral margins of posterolateral angles. Keel absent in the middle of anterior pronotal margin. Disc triangular, flat, with two distinctly developed tubercles on anterior portion. Triangle with lightly granulate, scabriculous, impunctate. Sides scabriculous, with smooth sculpture, superficially impressed punctures. Lateral lines of pronotal triangle straight. Posterolateral angles sharply acute, elongate, projected posterolaterally. Lateral fossae distinctly impressed. Basal fossae obtusely oval, deeply impressed. Posterior margin distinctly punctate (Figs 2D, 6A).

ELYTRA. Thick, roughened, bright metallic green striae, scabriculous, impressed basally as distinct fossae, with distinctly impressed punctation. Interstriae black, partially roughened, scabriculous, with almost effaced punctation; except for almost completely rough, bright metallic green first stria. Sutural margin without apical tooth (Fig. 6A).

Protibiae. Quadridentate with apical spine. 
TERgITE VIII. Bright metallic green; scabriculous; with rough, distinctly impressed punctures. Basal margin with thick, small setae.

GeNITALIA. Right lobe and left lobe of endophallite copulatrix similar in size. Right lobe obtusely triangular in shape, with apical portion projected posteriorly. Left lobe bent posteriorly, convex superiorly, lobed inferiorly. Central ridge and column similar in size (Fig. 1H).

\section{Minor male}

Like the major male, except for the reduction of secondary sexual characters (i.e., cephalic horn, pronotal triangle and tubercles, and pronotal posterolateral angles).

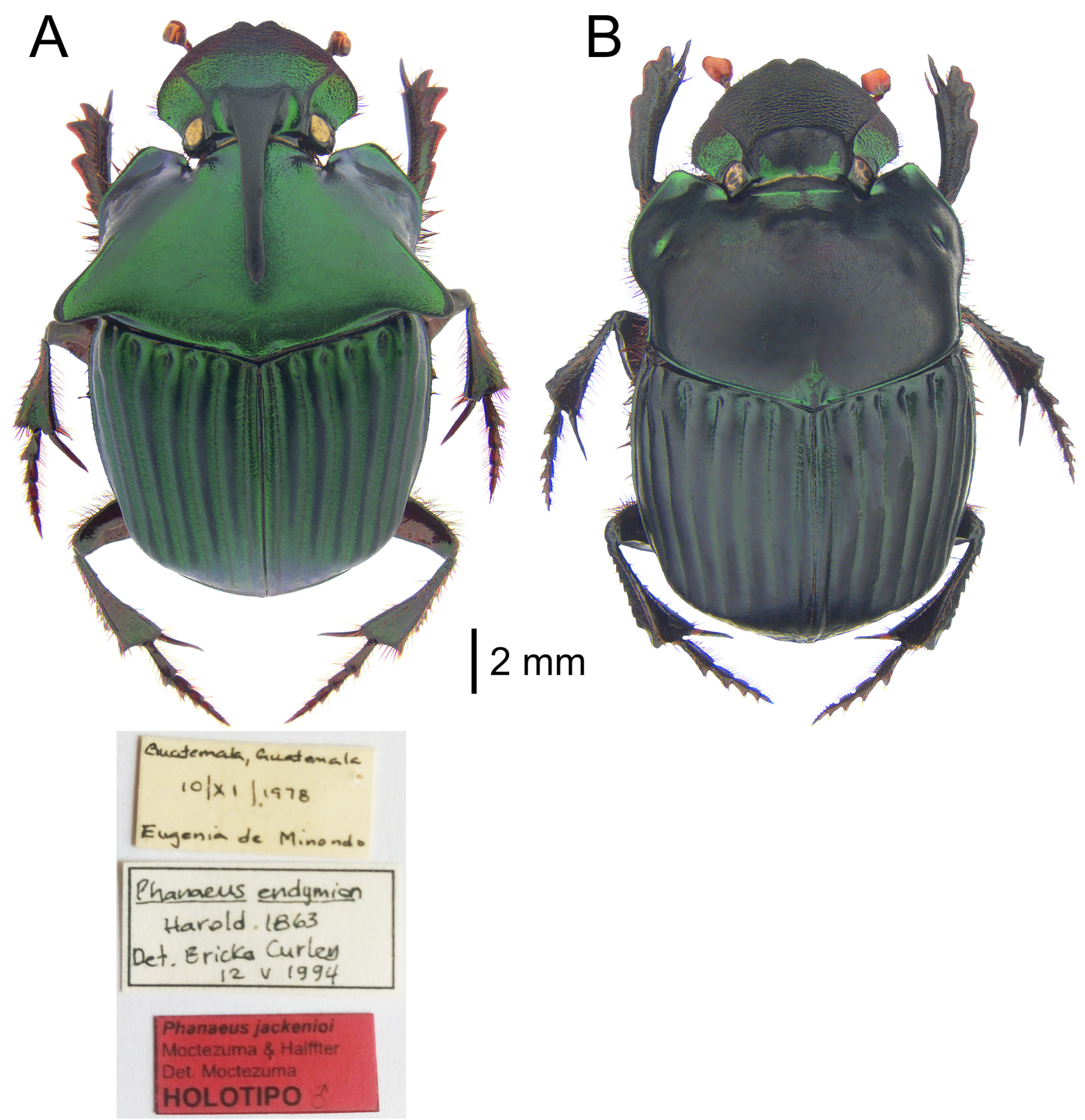

Fig. 6. Phanaeus jackenioi sp. nov. A. Holotype, ô (UVGC). B. ๆ (VMC). 


\section{Female}

Similar to the male, except for the head showing a cephalic trituberculate carina; carinate middle tubercle, less raised, slightly more frontally projected than lateral tubercles; lateral tubercles obtusely conical; frons with distinctly impressed punctures; pronotal sculpture completely smooth, with superficially impressed punctures; pronotum bright metallic green, with shining black, variable in size area on central portion of disc; pronotal process trituberculate, lacking concavity rounded pronotal tubercles, nearly aligned, with middle tubercle more developed than lateral tubercles; posterior pronotal midline completely effaced (Fig. 6B).

\section{Variation}

Mean length $17.3 \mathrm{~mm}(16.2-18.4 \mathrm{~mm})$.

\section{Distribution}

Inner slope of the Sierra Madre de Chiapas, south-central Guatemala and southeastern Chiapas (Fig. 15).

\section{Remarks}

The type series of $P$. jackenioi sp. nov. was originally labelled as $P$. pyrois. The new species was referred to as P. endymion by Edmonds (1994), Edmonds \& Zídek (2012), Lizardo et al. 2017, Moctezuma \& Halffter (2017) and GBIF Secretariat (2019a).

Phanaeus malyi Arnaud, 2002a

Figs 1I, 2E, 7, 16-17, 18J, 19J

Phanaeus pyrois malyi Arnaud, 2002a: 4.

Phanaeus pyrois - Bates 1887: 58 (in part, as a variety of P. pyrois). — Kohlmann et al. 2018: 78 (in part).

Phanaeus blanchardi (error) - Olsoufieff 1924: 92 (not P. blanchardi Harold, 1871: 114, in part). Vulcano \& Pereira 1967: 575 (in part). - Martínez \& Pereira 1967: 68 (in part, as synonym of P. funereus). - Edmonds 1972: 830, fig. 256 (in part); 1994: 3, 8, 45-46 (in part, as synonym of P. pyrois). - Arnaud 1982: 116 (in part, as synonym of $P$. funereus). - Krajcik 2006: 152 (as synonym of $P$. pyrois). — Edmonds \& Zídek 2012: 5, 13 (in part, as synonym of $P$. pyrois). Chamorro et al. 2019: 220-221 (in part, as synonym of $P$. pyrois).

Phanaeus pyrois malyi - Arnaud 2002b: 97 (as subspecies of P. pyrois). — Solís \& Kohlmann 2012: 1, 9-10 (as subspecies of P. pyrois). — Edmonds \& Zídek 2012: 1, 8, 13 (as synonym of P. pyrois). Krajcik 2006: 152 (as subspecies of P. pyrois). — Kohlmann et al. 2018: 78.

Phanaeus (Notiophanaeus) pyrois malyi - Arnaud 2002b: 96 (as subspecies of $P$. pyrois).

Phanaeus malyi - Solís \& Kohlmann 2012: 1, 7, 31, fig. 1. — Edmonds \& Zídek 2012: 3, 6 (as synonym of P. pyrois). — Kohlmann et al. 2018: 67-69, 78-80, 82, 88-89, figs 8, S1b. — Gillett \& Toussaint 2020: fig. 4.

Phanaeus (Notiophanaeus) malyi - Kohlmann et al. 2018: 78.

Non Phanaeus olsoufieffi (error) - Balthasar 1939: 242 (in part). — Edmonds 1994: 8, 45-46 (in part, as synonym of $P$. pyrois). — Arnaud 2002b: 96 (in part). — Krajcik 2006: 152 (in part, as synonym of P. pyrois). — Edmonds \& Zídek 2012: 3, 5-6 (in part, as synonym of P. pyrois).

Non Phanaeus bothrus (error) - Blackwelder 1944: 209 (in part). — Martínez \& Pereira 1967: 68 (in part, as synonym of $P$. funereus). — Edmonds 1994: 8, 45 (in part, as synonym of $P$. pyrois). Arnaud 2002b: 97 (in part, as synonym of $P$. olsoufieffi). - Krajcik 2006: 152 (in part, as synonym of P. pyrois). — Edmonds \& Zídek 2012: 3, 5 (in part, as synonym of $P$. pyrois). 
Non Phanaeus (Phanaeus) blanchardi (error) - Martínez \& Pereira 1967: 68 (in part, as synonym of P. funereus).

Non Phanaeus (Phanaeus) olsoufieff (error) - Martínez \& Pereira 1967: 68 (in part, as synonym of P. funereus).

Non Phanaeus (Notiophanaeus) pyrois olsoufieff (error) - Arnaud 2002b: 96 (in part).

Non Phanaeus pyrois olsoufieff (error) - Arnaud 2002b: 98; 2018: 4 (in part).

\section{Diagnosis}

Easily diagnosed species by the bright black colour with red-green sheen on frontolateral angles of pronotum (Fig. 2E); elytral striae fine, smooth, impressed basally as distinct fossae (Fig. 7). The rest of black species within the P. endymion species group (P. funereus, P. olsoufieffi, P. panamensis sp. nov.) are differentiated from $P$. malyi by the elytral striae not strongly impressed basally as distinct fossae and the shape of the endophallite copulatrix (Fig. 1).

\section{Type material}

Holotype (not studied)

COSTA RICA • Õ, Arnaud 2002a: 3; Puntarenas, Carara National Park, Estación Quebrada Bonita; originally deposited at INBIO; MNCR.

Non-type material revised $(10 \hat{\partial}, 6 \propto \uparrow q)$

COLOMBIA • 1 đ; unknown locality; "[Illegible data]/Ex-musæo D. Sharp 1890/Museum Paris ex Coll. R. Oberthur/PARALECTOTYPE/PARALECTOTYPE Phanaeus (Phanaeus) blanchardi Olsoufieff, 1924/MNHN EC10569"; MNHN.

COSTA RICA - Puntarenas • 1 đ̊; "San Luis, San Luis Vly. VII-29-1996. Coll. Louis La Pierre"; VMC • 1 +; “6km S. San Vito. 27-IV/7-V 1967. 100m. D.F. Viers col. human feces?”; TAMU • 1 ð”; "S.Vito, Las Cruces. July 1982. B.Gill. 1200 m"; IEXA・1 $\nsim, 1$ \%; same collection data as for preceding;

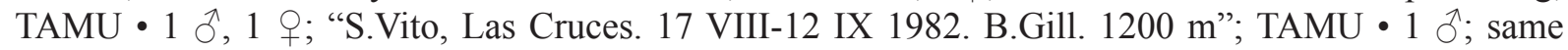
collection data as for preceding; UVGC • 1 O; "S.Vito, Las Cruces. 15-18 VIII 1982. B.Gill. 1200 m"; VMC • 1 ठె; "Rincón de Osa. 3-X-69. G. Halffter y P. Reyes C., col. Selva tropical lluviosa. Cebo excremento. Día"; GHC • 1 q; "Rincón de Osa. 5-X-69. G. Halffter y P. Reyes C., col. Selva tropical lluviosa. Cebo excremento. Día”; GHC • 1 + ; "Rincón de Osa. 30-IX-69. G. Halffter y P. Reyes C., col. Selva tropical lluviosa. Cebo excremento. Día (11-17 hrs.)"; VMC • 1 ô;; "Rincón de Osa. 22-5-1965. Col. P. Kazan"; GHC.

PANAMA - Chiriquí • 1 đ̊; "Cerro Hornito 15 km NE Gualaca. 17-21 VI 1982. B.Gill. 1200 m."; TAMU • 1 đ̊; “Cerro Pelota 4 km N Sta.Clara. 9-18 VIII 1982. B.Gill. 1500 m.”; VMC.

\section{Type locality}

Costa Rica, Puntarenas, Carara National Park, Estación Quebrada Bonita.

\section{Redescription}

\section{Major male}

HEAD. Completely bright black. Clypeus bidentate, with roughened sculpture. Genae with roughened sculpture. Cephalic horn curved posteriorly over pronotum (Figs 2E, 7A).

Pronotum. Keel absent in the middle of anterior pronotal margin. Disc triangular, flat; with two weakly developed, elongate tubercles on anterior portion. Triangle bright black, smooth, scabriculous, impunctate. Sides bright black, becoming bright metallic red-green; scabriculous, with smooth sculpture, almost effaced punctures. Lateral lines of triangle straight. Posterolateral angles short, widened. Lateral 
fossae distinctly impressed. Basal fossae distinctly to superficially impressed. Posterior margin with distinctly to superficially impressed punctures (Figs 2E, 7A).

ELYTRA. Striae fine, smooth, completely bright black, with superficially impressed to effaced punctures, scabriculous, impressed basally as distinct fossae. Interstriae bright black, with smooth surface, scabriculous, impunctate or with almost effaced punctures. Sutural margin without apical tooth (Figs 7A).

Protibiae. Quadridentate with apical spine.

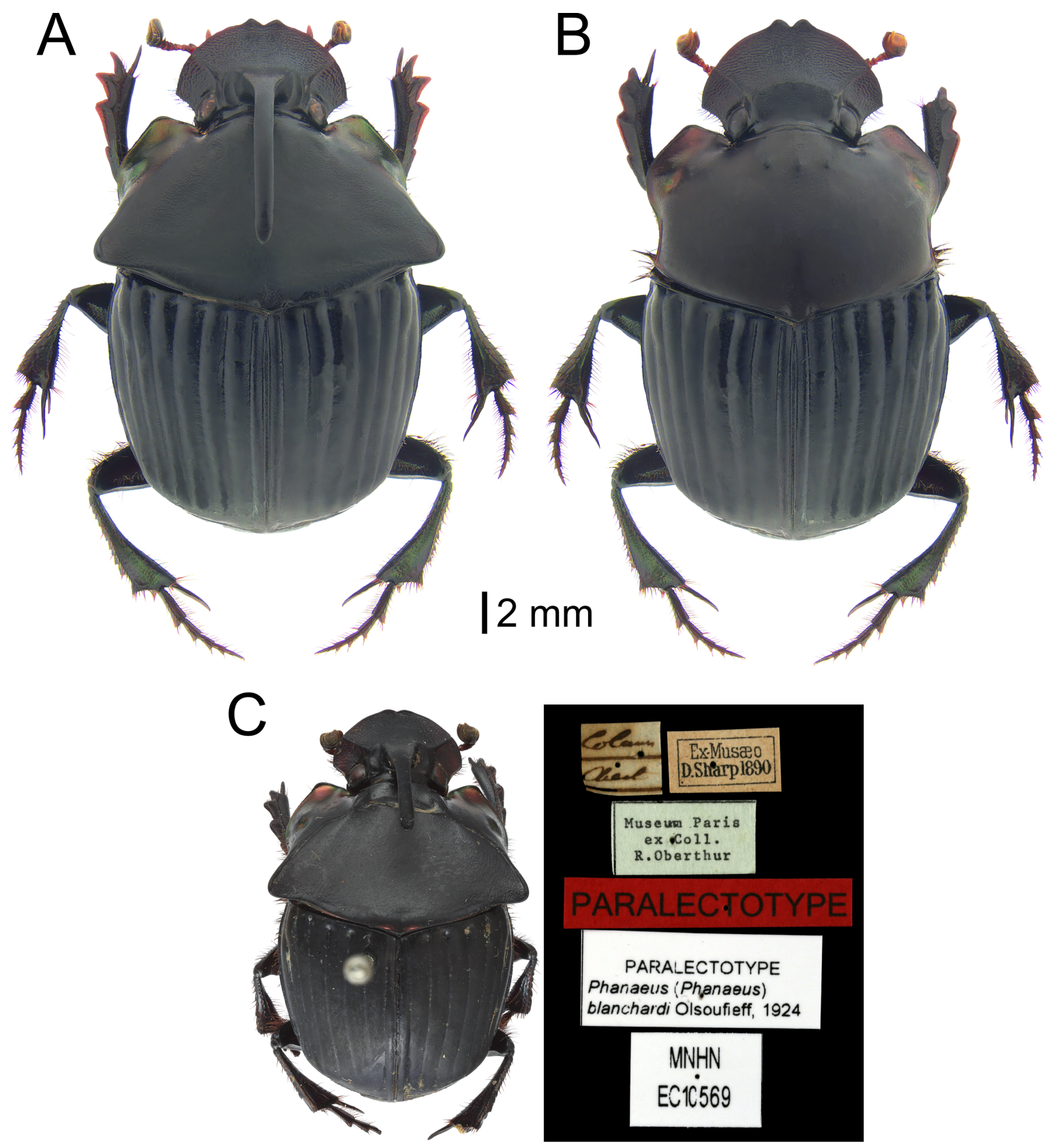

Fig. 7. Phanaeus malyi Arnaud, 2002. A. $\widehat{\partial}$ (TAMU). B. $q$ (TAMU). C. Colombian specimen previously labelled as a paralectotype of $P$. blanchardi Olsoufieff, 1924 (by Christophe Rivier, Muséum national d'histoire naturelle, Paris, France) (MNHN). 
TERgite VIII. Bright metallic red-green, scabriculous sculpture; with rough, superficially impressed punctures. Basal margin with setae variable in size.

Genitalia. Right and left lobes of endophallite copulatrix similar in size. Right lobe obtusely triangular in shape, rounded superiorly. Left lobe obtusely lobed. Central ridge less developed than central column (Fig. 1I).

\section{Minor male}

Like the major male, except for the reduction of the secondary sexual characters (i.e., cephalic horn, pronotal triangle and tubercles, and pronotal posterolateral angles).

\section{Female}

Similar to the male, except for the head showing a cephalic trituberculate carina, with nearly aligned, rounded or carinate, weakly developed tubercles; middle tubercle slightly more developed than lateral tubercles; frons with superficially impressed punctures; pronotum with almost effaced punctures; pronotal process trituberculate, lacking concavity; middle pronotal tubercle more developed, slightly more projected posteriorly than lateral tubercles; all tubercles rounded in shape; posterior pronotal midline completely effaced to almost effaced (Fig. 7B).

\section{Variation}

Mean length $17.8 \mathrm{~mm}(12.8-20.5 \mathrm{~mm})$. Colour variation was not found for P. malyi.

\section{Distribution}

Southern Pacific costal area, Costa Rica, Panama and Colombia (Figs 16-17). The specimens revised by us represent the first accurate records of $P$. malyi from Panama. Apparently, the distributions of $P$. malyi and $P$. panamensis sp. nov. show a significant area of sympatry and both species may be collected in the same locality (e.g., Cerro Hornito, Panama). Nevertheless, P. malyi and P. panamensis sp. nov. are confidently identified by the diagnosis provided herein and putative hybrid specimens were not found by us. The MNHN EC10569 specimen represents the first record for P. malyi in Colombia. Nevertheless, the illegible label data prevents us to provide an accurate locality (Fig. 7C). The extent of the distribution of $P$. malyi in Colombia needs to be confirmed by future research.

\section{Remarks}

Phanaeus malyi was considered by previous authors as a synonym of P. pyrois (Edmonds \& Zídek 2012). Nevertheless, clear differences in the external and genital morphology of $P$. malyi were found by us. These differences support the full species status suggested by Solís \& Kohlmann (2012) and Kohlmann et al. (2018). When revising the type material housed at MNHM, a Colombian minor male specimen of P. malyi was found to be labelled as a paralectotype of P. blanchardi (Fig. 7C, MNHN EC10569).

Phanaeus olsoufieffi Balthasar, 1939 stat. rev.

Figs $1 \mathrm{~J}, 2 \mathrm{~F}, 8,17,18 \mathrm{~K}, 19 \mathrm{~K}$

Phanaeus blanchardi Olsoufieff, 1924: 92 (not P. blanchardi Harold, 1871: 114).

Phanaeus olsoufieffi Balthasar, 1939: 242.

Phanaeus bothrus Blackwelder, 1944: 209.

Phanaeus (Phanaeus) blanchardi - Martínez \& Pereira 1967: 68 (as synonym of P. funereus).

Phanaeus (Phanaeus) olsoufieffi - Martínez \& Pereira 1967: 68 (as synonym of $P$. funereus).

Phanaeus bothrus - Martínez \& Pereira 1967: 68 (as synonym of P. funereus). — Edmonds 1994: 8, 45 (as synonym of $P$. pyrois). - Arnaud 2002b: 97 (as synonym of P. olsoufieffi). — Krajcik 2006: 152 (as synonym of $P$. pyrois). — Edmonds \& Zídek 2012: 3, 5 (as synonym of P. pyrois). 
Phanaeus blanchardi - Vulcano \& Pereira 1967: 575. — Martínez \& Pereira 1967: 68 (as synonym of $P$. funereus). — Edmonds 1972: 830, fig. 256; 1994: 3, 8, 45-46 (as synonym of P. pyrois). Arnaud 1982: 116 (as synonym of $P$. funereus). — Krajcik 2006: 152 (as synonym of $P$. pyrois). Edmonds \& Zídek 2012: 5, 13 (as synonym of P. pyrois). — Chamorro et al. 2019: 220-221 (as synonym of $P$. pyrois).

Phanaeus olsoufieffi - Edmonds 1994: 8, 45-46 (as synonym of $P$. pyrois). - Arnaud 2002b: 96. Krajcik 2006: 152 (as synonym of $P$. pyrois). — Edmonds \& Zídek 2012: 3, 5-6 (as synonym of P. pyrois).

Phanaeus (Notiophanaeus) pyrois olsoufieffi - Arnaud 2002b: 96.

Phanaeus pyrois olsoufieffi-Arnaud 2002b: 98; 2018: 4, pl. 1, figs d-e.

Non Phanaeus pyrois (error). - Medina et al. 2001: 140 (in part). — Moctezuma \& Halffter 2017: 55 (in part). - Moctezuma et al. 2017: 114, 130 (in part).

\section{Diagnosis}

This is the largest species within the $P$. endymion species group, frequently attaining $21-24 \mathrm{~mm}$ in length. Phanaeus olsoufieffi is diagnosed by the black colour with bright metallic red-green sheen; and elytral striae not strongly impressed basally (Fig. 8). This species is easily separated from the closely related P. panamensis sp. nov. by the larger body size and endophallite copulatrix (Fig. 1). Additionally, the major males of $P$. olsoufieffi are diagnosed by the distinctly developed keel in the middle of anterior pronotal margin; and posterolateral angles rounded, strongly developed, and projected laterally (Figs $2 \mathrm{~F}$, $8 \mathrm{~A})$.

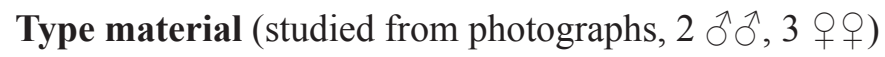

\section{Lectotype}

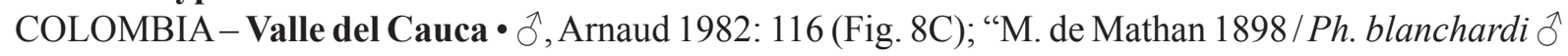
Olsuf. det. G. Olsufiew./Phanaeus apollinaris Muzo 1928/Muséum Paris 1952 Coll R. Oberthur/P. blanchardi Ols. LECTOTYPE §̋ P. ARNAUD DET 1980/Lectotype/Phanaeus pyrois Bates, Det. W. D. Edmonds '83/MNHN EC10566"; MNHN.

\section{Paralectotypes}

COLOMBIA - 1 ô; "ExMusæo VAN LANSBERGE/Museum Paris ex. Coll. R. Oberthur /PARALECTOTYPE/Phanaeus blanchardi Ols. PARALECTOTYPE $\lesssim$ P. ARNAUD DET 1981 / Phanaeus pyrois Bates/Det. W. D. Edmonds '83"/ MNHN EC10568”; MNHN. - Boyacá • 1 \%; "Muzo/Coll.E. Steinheil/MuseumParisex.Coll.R.Oberthur/PARALECTOTYPE/PARALECTOTYPE Phanaeus (Phanaeus) blanchardi Olsoufieff, 1924/MNHN EC10570"; MNHN EC10570. - Valle del Cauca - 1 \%; "Santa Rosa entre S. Francisco \& Carthago. Eujenio Garzon Aout 1878"; MNHN. Unknown locality • 1 ; ; “(Illegible data)/Ex-musæo D. Sharp 1890/Ph. blanchardi $q$ Olsuf. det. G. Olsoufiew. / Museum Paris ex Coll. R. Oberthur/Phanaeus blanchardi $q$ 's. PARALECTOTYPE $q$ P. ARNAUD DET 1981 / PARALECTOTYPE/ Phanaeus pyrois Bates Det. W. D. Edmonds '83 / MNHN EC10567"; MNHN.

\section{Non-type material revised $(24 \hat{\jmath} \widehat{\partial}, 16 q \rho)$}

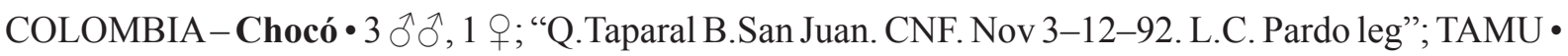

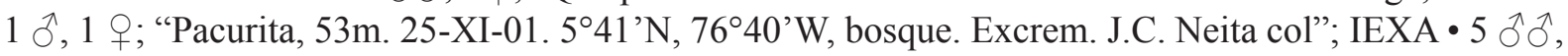
5 우; same collection data as for preceding; TAMU $\bullet 1 \hat{0}, 1 \%$; same collection data as for preceding;

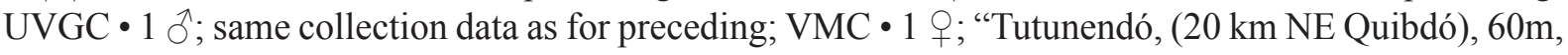
26-XI-01. J.C. Neita col”; TAMU • 3 우; “Unión Panamericana, 115m. 5³2’45N, 76²4'33”'W (No date) J.C. Neita col”; TAMU • 1 ô, 1 क ; “'Lloró, (3k km S Quibdó) 5³0’ N, 76³3.5’W 90 m. J.C. Neita

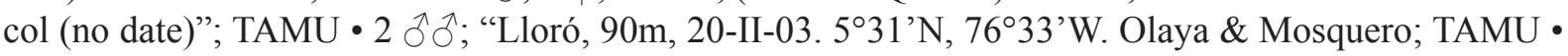


1 +; same collection data as for preceding; VMC. - Tolima • 1 \% ; "Honda"; GHC. - Valle del Cauca •

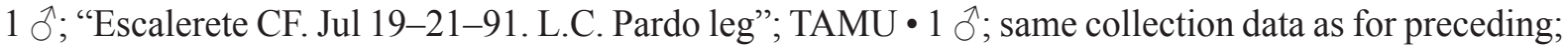
VMC • 1 ô, 1 q; "B/Ventura B.Calima, C.F. 50 msnm. Col. ME Hitchcox"; TAMU • 1 o, 1 o; "S30-

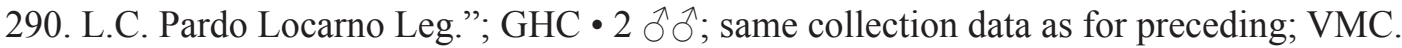

ECUADOR - Esmeraldas • $2 \hat{\jmath} \widehat{\jmath}$; “Charco Vicente. Ex.Pitfall heces humanas. 16/05/01. J. Quito F. Añapa"; TAMU.

\section{Type locality}

Colombia, Valle del Cauca.

\section{Redescription}

\section{Major male}

HEAD. Clypeus bidentate, black anteriorly, bright metallic red posteriorly, with green sheen; roughened sculpture. Genae bright metallic red, with green sheen; roughened sculpture. Front black. Cephalic horn black, curved posteriorly over pronotum (Figs 2F, 8A).

Pronotum. Carinate, distinctly developed keel in the middle of anterior pronotal margin. Disc triangular, flat, with two distinctly developed tubercles on anterior portion. Triangle completely dull black, with bright metallic red sheen; completely smooth, scabriculous, impunctate. Sides bright metallic red, with green sheen; smooth sculpture, scabriculous, with effaced to almost effaced punctures. Lateral lines of pronotal triangle straight. Posterolateral angles rounded, strongly developed, projected laterally. Lateral fossae distinctly impressed. Basal fossae obtusely oval, deeply impressed to effaced. Posterior margin impunctate, becoming occasionally bright metallic red (Figs 2F, 8A).

Elytra. Striae fine, smooth, dull black, with superficially impressed to effaced punctation, scabriculous, not strongly impressed basally. Interstriae dull black, smooth, scabriculous, impunctate. Sutural margin without apical tooth (Fig. 8A).

Protibiae. Quadridentate with apical spine.

TERGITE VIII. Bright metallic red, with green sheen; scabriculous; with rough, superficially impressed punctures. Basal margin with setae variable in size.

GenitaLia. Right lobe of endophallite copulatrix slightly more developed than left lobe. Right lobe obtusely triangular in shape; weakly developed, projected frontally. Left lobe concave superiorly, lobed inferiorly. Central ridge less developed than central column (Fig. 1J).

\section{Minor male}

Like the major male, except for the reduction of secondary sexual characters (i.e., cephalic horn, pronotal triangle and tubercles, and pronotal posterolateral angles).

\section{Female}

Similar to the male, except for the head showing a cephalic trituberculate carina; with weakly developed tubercles; carinate middle tubercle, slightly more frontally projected and more developed than lateral tubercles; frons with superficially impressed punctures; pronotal sculpture smooth, with almost effaced to effaced punctures; pronotum almost completely black, becoming posteriorly and laterally bright metallic red with green sheen; pronotal process trituberculate, lacking concavities; pronotal tubercles weakly developed, well-spaced, with middle tubercle more developed and posteriorly projected than lateral tubercles; posterior pronotal midline completely effaced (Fig. 8B). 


\section{Variation}

Mean length $20.1 \mathrm{~mm}(15.9-23.9 \mathrm{~mm})$. Minor males occasionally show the pronotal disc almost completely bright metallic red, with green sheen.

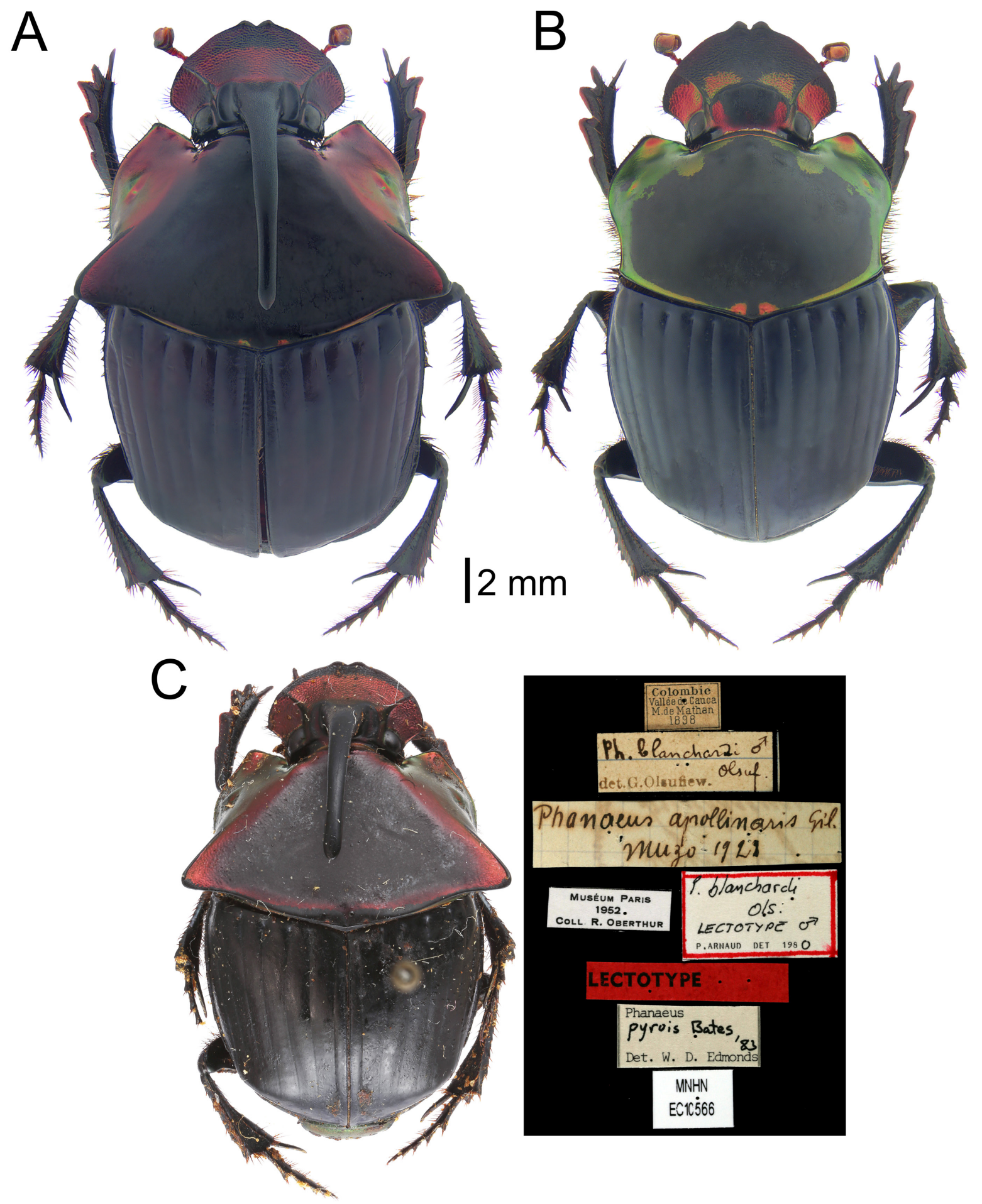

Fig. 8. Phanaeus olsoufieffi Balthasar, 1939 stat. rev. A. §̊ (TAMU). B. $q$ (TAMU). C. Lectotype $\widehat{o}$ (by Christophe Rivier, Muséum national d'histoire naturelle, Paris, France) (MNHN). 


\section{Distribution}

Pacific Slope of the Andes, north-central Colombia and northern Ecuador (Fig. 17). Previous authors reported P. olsoufieffi from Panama (Arnaud 2002b; Kohlmann et al. 2018). Nevertheless, these authors confused $P$. olsoufieffi with $P$. panamensis sp. nov. The specimens revised herein are the first accurate records of $P$. olsoufieff from Ecuador. The distributions of $P$. olsoufieffi and $P$. funereus show a significant area of sympatry. Nevertheless, we did not find any putative hybrid specimens.

\section{Remarks}

Phanaeus olsoufieffi was considered as a synonym of P. pyrois by previous authors (Edmonds 1994; Edmonds \& Zídek 2012). Nonetheless, a diagnosis and an updated key to separate P. olsoufieffi and closely related species are provided by us. As a consequence, $P$. olsoufieffi is confidently resurrected herein from previous synonymy and full species status is assigned to it. The lectotype of $P$. olsoufieffi is a minor male (Fig. 8C). Therefore, the redescription mainly relies on the type series and some specimens $(n=8)$ collected from the type locality (Valle del Cauca, Colombia). When revising the type material deposited at MNHM, we were not able to find out the locality data for a Colombian female paralectotype of P. olsoufieffi (MNHN EC10567). Its locality data is probably indicated in an illegible label. Additionally, we found out that a paralectotype of P. olsoufieffi pertained to P. malyi (Fig. 7C, MNHN EC10569). Consequently, we conclude that the type series of $P$. olsoufieffi lumped together two distinct species. Previous authors (Arnaud 1982; 2002a, 2002b; Edmonds 1994; Edmonds \& Zídek 2012) did not realize this fact that solves the controversy considering $P$. malyi as a junior subjective synonym of $P$. olsoufieffi or not (Edmonds \& Zídek 2012; Solís \& Kohlmann 2012; Kohlmann et al. 2018).

Phanaeus pacificus sp. nov. urn:1sid:zoobank.org:act:2414CDB0-3376-4634-8A29-06EFB556E6D0

Figs $1 \mathrm{~K}, 2 \mathrm{G}, 9,18 \mathrm{~L}, 19 \mathrm{~L}$

\section{Diagnosis}

Species typically dark blue or blue-green (Figs $2 \mathrm{G}, 9$ ), easily separated from the closely related by the elytral striae deeply punctate, with each puncture forming a distinct fossa, giving a completely roughened surface to all striae (Fig. 9). Additionally, the major males of $P$. pacificus sp. nov. and $P$. jackenioi sp. nov. are distinguished by the carinate keel in the middle of anterior pronotal margin of the former (Fig. 2).

\section{Etymology}

The specific epithet refers to the Pacific slope, where the new species occurs.

Type material $(21 \hat{\jmath}, 22$ q $ᄋ)$

\section{Holotype}

GUATEMALA • đ̊; Suchitepéquez, Patulul, Finca Terrales, Casco Finca; "Patulul, Finca Terrales. Casco Finca. 750 m. 7-8 noviemb. 2006. Monzón, Giardina, Frank"; UVGC.

\section{Paratypes}

EL SALVADOR・ 1 ○’; “1-10-95. T-carne. Denninger”; VMC.

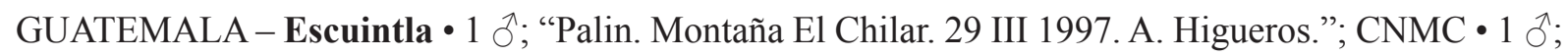
same collection data as for preceding; UVGC $\bullet 1$ \%; same collection data as for preceding; VMC $\bullet 1$ 万; "Palín, Fca. El Chilar. IX 2013. S. Secaira"; VMC• 1 \&; "Palín, Montaña El Chilar. 14.35310, -90728190.

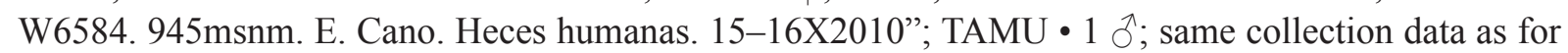


preceding; VMC. - Retalhuleu・ 1 ○;; “Chicacaho. 21 III 1992. P. Hunziker”; UVGC. - Suchitepéquez• 1 +; "Santa Bárbara. Finca Panamá. Periquera. 1,127m. Oct. 2007. 145323349 -91.1976111- Pérez,

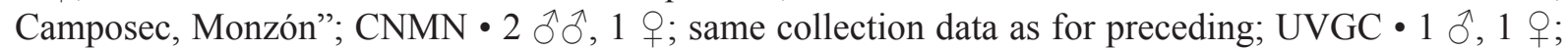
same collection data as for preceding; VMC • 1 đ; "Santa Bárbara. Finca Panamá. "abato". 1,177m. Diciem. 2007. 14³2.118 -91¹2.281. Pérez, Camposec, Monzón”; IEXA • 2 q $q$; "Santa Bárbara. Finca Panamá. Periquera. 1,127m. Nov. 2007. 145323349 -91.1976111- Pérez, Camposec, Monzón”; UVGC • $1 \partial^{\top}$; same collection data as for preceding; TAMU.

MEXICO - Chiapas • 1 đ̧; "Unión Roja, La Boquilla. Alt. 500m. Selva pert. 9.V.84. NTP.80. J.A.

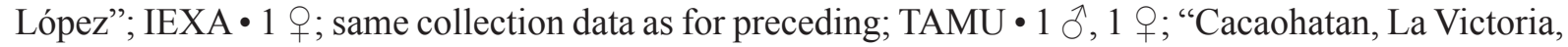
21-V-82. Cafetal, Alt. 430m. M.A. Morón, col. NTP"; IEXA • 1 q; "Cacaohatan, La Victoria, 15-IX82. Cafetal, Alt. 430m. NTP. J. Valenzuela, col.”; IEXA • 1 ' ; same collection data as for preceding; TAMU • 1 क; "Cacaohatan, La Victoria, 15-XII-81. Cafetal, Alt. 430m. M.A. Morón col. NTP"; IEXA • 1 क; "Cacaohatan, La Victoria, 15-VII-82. Cafetal, Alt. 430m. M.A. Morón col. NTP"; IEXA • 1 \&; “Cacaohatan, La Victoria, 18-V-82. Cafetal, Alt. 430m. M.A. Morón col. NTP”; IEXA • 1 đ̄; "Cacaohatan, La Victoria, 25-XI-81. Cafetal, Alt. 430m. NTP. J. Valenzuela, col.”; CMNC • 1 q; same collection data as for preceding; IEXA - 1 क; "Cacaohatan, La Victoria, 2-IX-81. Cafetal, Alt. 430m. M.A. Morón col. NTP”; IEXA • 1 q; "Cacaohatan, La Victoria, 2-III-82. Cafetal, Alt. 430m. M.A. Morón col. NTP" ; CMNC • 3 우 ; same collection data as for preceding; IEXA • 1 ○; "Cacaohatan, Sn. José de la Victoria, 10-III-92. Coprotrampa 24 hrs. M.A. Morón, col.”; IEXA • 1 đ’; "Cacaohatan, Sn. José de la Victoria, 25-V-82. Coprotrampa 6 días. M.A. Morón, col.”; IEXA • 1 đ̊; "Cacaohatan, La Victoria, 15-III-82. Cafetal, Alt. 430m. J. Valenzuela, col. NTP.”; VMC • 1 क; “Cacaohatan, La Victoria, 2-III-82. Cafetal, Alt. 430m. J. Valenzuela, col. NTP."; VMC • 1 ô, 1 o ; "Rosario Izapa. 19-20-V-63. G. Halffter. A. Martínez. cols.”; GHC • 1 đ , 1 q; “Unión Roja. La Boquilla, 11-VI-83 coprotr. M.A. Morón”; UVGC.

\section{Type locality}

Guatemala, Suchitepéquez, Patulul, Finca Terrales, Casco Finca.

\section{Description}

Major male (holotype)

Length $19.4 \mathrm{~mm}$.

HEAD. Clypeus bidentate, black on anterior margin, dark blue on posterior portion, roughened sculpture. Genae dark blue, with roughened sculpture. Front black, dark blue on portions adjacent to cephalic horn. Cephalic horn black, curved posteriorly over pronotum (Figs 2G, 9A).

PRonotum. Uniformly dark blue, becoming completely black on lateral margins of posterolateral angles and posteriorly. Carinate, distinctly developed keel in the middle of anterior pronotal margin. Disc triangular, flat, with two distinctly developed tubercles on anterior portion. Triangle lightly granulate, scabriculous, impunctate. Sides with smooth sculpture, scabriculous, with superficially impressed punctures. Lateral lines of pronotal triangle straight. Posterolateral angles acute, strongly developed, sharply projected posteriorly. Lateral fossae distinctly impressed. Basal fossae obtusely oval, distinctly impressed. Posterior margin with superficially impressed punctures (Figs 2G, 9A).

ELYTRA. Striae thick, dark blue, with distinctly impressed punctures, scabriculous, impressed basally as distinct fossae. Interstriae black, smooth, scabriculous, with superficially impressed punctures; except for the roughened surface on first interstriae. Sutural margin without apical tooth (Fig. 9A).

Protibiae. Quadridentate with apical spine. 
TERgite VIII. Dark metallic blue-green, scabriculous; with rough, superficially impressed punctures. Basal margin with setae variable in size.

Genitalia. Right and left lobes of endophallite copulatrix similar in size. Right lobe obtusely triangular in shape, concave medially. Left lobe strongly developed, concave posterosuperiorly. Central ridge and column similar in size (Fig. 1K).

\section{Minor male}

Like the major male, except for the reduction of the secondary sexual characters (i.e., cephalic horn, pronotal triangle and tubercles, keel on anterior margin, and pronotal posterolateral angles).

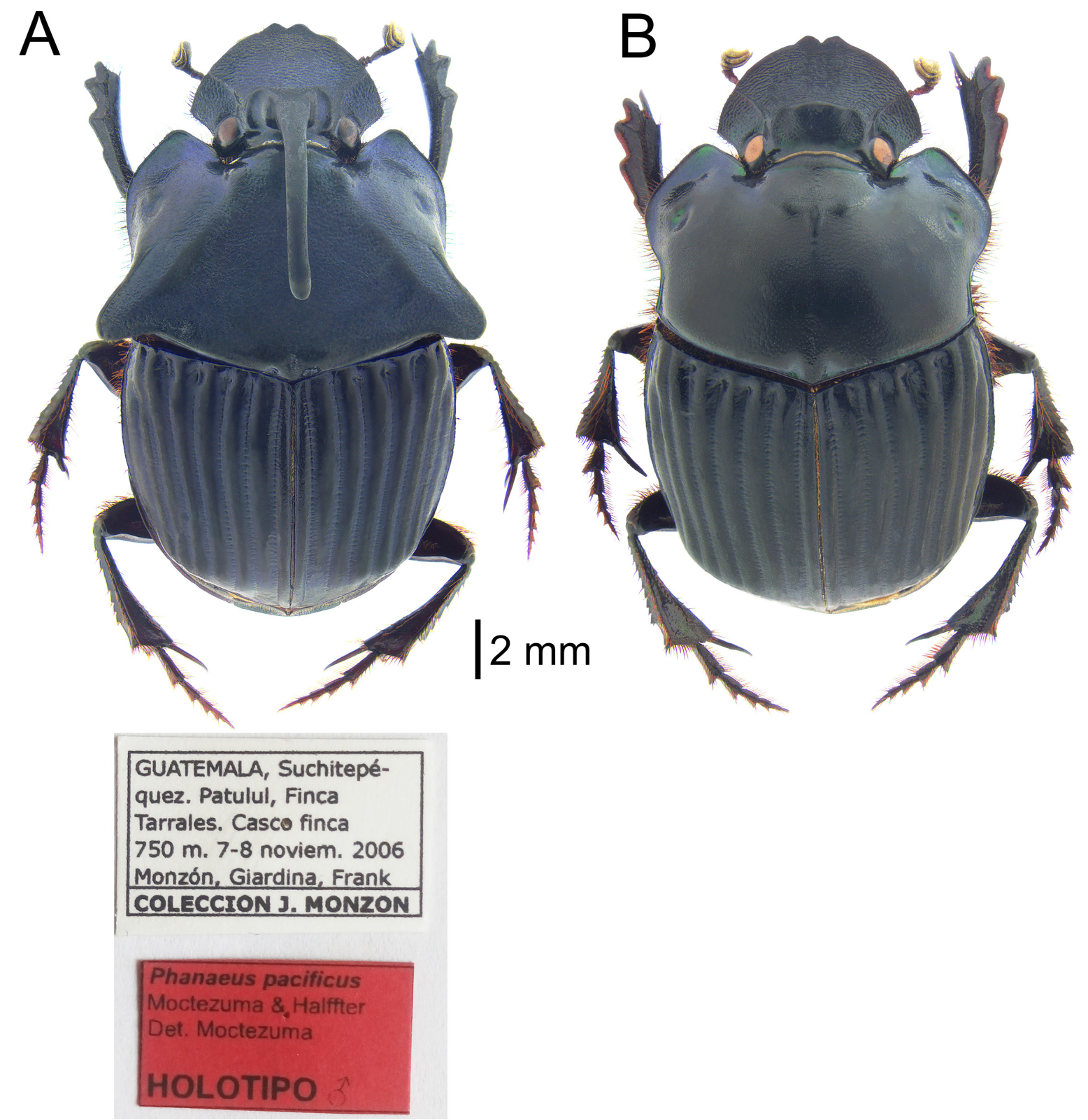

Fig. 9. Phanaeus pacificus sp. nov. A. Holotype, §̊ (UVGC). B. † (IEXA). 
Female

Similar to the male, except for the head showing a cephalic trituberculate carina; with conical tubercles; middle tubercle slightly more projected frontally than lateral tubercles; lateral tubercles slightly more raised than middle tubercle; frons distinctly impressed, rough punctures; pronotal sculpture completely smooth, with distinctly impressed punctures; pronotum almost completely dull black in the central portion, dark metallic blue, or blue-green laterally and posteriorly; pronotal process trituberculate, lacking concavities; pronotal tubercles nearly aligned; with rounded to dentiform middle tubercle, more developed than lateral tubercles; posterior pronotal midline superficially impressed (Fig. 9B).

\section{Variation}

Mean length $17.1 \mathrm{~mm}(14.1-20.2 \mathrm{~mm})$. A rare bright metallic green or yellow-green with a red sheen colour morph was found. The smaller males may show a keel weakly developed to completely effaced in the middle of anterior pronotal margin.

\section{Distribution}

Pacific slope of the Sierra Madre de Chiapas; Chiapas, Guatemala and El Salvador (Fig. 15).

\section{Remarks}

This new species was referred to as P. endymion (Morón 1987; Edmonds 1994; Horgan 2001, 2008; Edmonds \& Zídek 2012; Cancino-López et al. 2014; Lizardo et al. 2017; Moctezuma \& Halffter 2017; GBIF Secretariat 2019a; Pablo-Cea et al. 2020) and P. pyrois (GBIF Secretariat 2019b) by previous authors and specimen labels. Nevertheless, the distribution areas of all the closely related species are not sympatric and P. pacificus sp. nov. is distinctly diagnosable.

Phanaeus panamensis sp. nov.

urn:lsid:zoobank.org:act:C10343D8-4C59-4F57-987F-4234062447E3

Figs $1 \mathrm{~L}, 2 \mathrm{H}, 10,16,18 \mathrm{M}, 19 \mathrm{M}$

\section{Diagnosis}

The new species is easily diagnosed within the P. endymion species group by the dull black colour with bright metallic red-green sheen dorsally (Figs $2 \mathrm{H}, 10)$; and elytral striae not strongly impressed basally as distinct fossae (Fig. 10). Phanaeus panamensis sp. nov. is distinguished from P. olsoufieffi by its smaller body size (rarely attaining 20-21 mm in length); and the major males with obsolete keel in the middle of anterior pronotal margin (Fig. $2 \mathrm{H}$ ); and posterolateral angles weakly developed, widened, slightly projected posteriorly (Fig. 10A). Furthermore, the pronotal disc in P. olsoufieffi is distinctly darker and smoother (Figs 2F, 8A).

\section{Etymology}

The specific epithet refers to Panama, where a majority of the type series was collected.

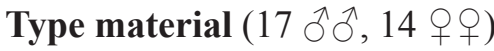

Holotype

PANAMA • đ’; Panamá, Cerro Campana; “Cerro Campana, 850m. 840’N, 7956’W. 19 Sept. '71. Stockwell. Manure trap"; TAMU.

\section{Paratypes}

COSTA RICA - Heredia • 1 đ̊; "Estación La Selva, Río Puerto Viejo, 84W/10²8’N. 12-IX-1969. G. Halffter y P. Reyes col."; GHC • 1 §’; same collection data as for preceding; VMC. 
PANAMA - Chiriquí •1 ổ; "Cerro Hornito, 15 km W Gualaca. 17-21 VI 1982. B.Gill. 1200 m”; TAMU • 1 क; "Cerro Hornito, 15 km W Gualaca. 21 VI-16 VII 1982. B.Gill. 1200 m"; TAMU. Coclé • 1 क; "El Valle, VI-10-13-1985, E.Kiley \& D.Rider"; CNMC • 1 q; same collection data as for preceding; TAMU $\bullet 1 \hat{\delta}, 1$; ; same collection data as for preceding; UVGC $\bullet 1 \hat{\jmath}$; same collection data as for preceding; VMC • 1 क; "El Valle de Antón, VI 5 1945. 2500 ft. C.D. Michener"; TAMU.-

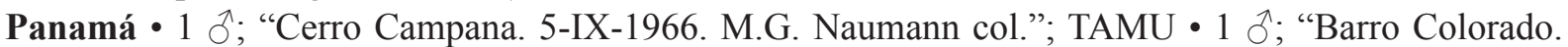
Canal Zone. May 1929. Darlington"; TAMU • 1 đ̊; "Canal Zone B.C.I. 6-XII-1975. Rat carrion trap. Col. O.P.Young"; TAMU • 1 đ̊; "Canal Zone B.C.I. 1,2-XI-1975. Human feces trap. Col. O.P.Young”;

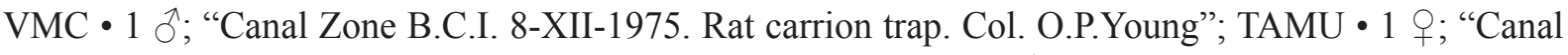
Zone, Fort Kobbe, VI-4-21-1985. E.G., Riley”; IEXA•TAMU: 1 §, 3 ㅇq; same collection data as for preceding; TAMU • 1 क ; same collection data as for preceding; VMC • 1 + ; "Chepo-Carti Rd. 1-22VIII-1982. B-Gill. 400 m"; TAMU • 1 ऽ;; "Chepo-Carti Rd. 6-24-VI-1982. B-Gill. 400 m”; CNMC• $1 \partial^{\top}$; same collection data as for preceding; IEXA • 2 q+ ; same collection data as for preceding; TAMU • 1 †; “9 km SE Bayano Bridge. 9¹0’N, 7846’W. 8 Sept '74. H. Stockwell. Manure trap”; VMC • 1 ○’; "Barro Colo Isld. Canal Zone. 1.7.1929. Collector C. H. Curran"; GHC • 1 đ̃; "Canal Zone. 1951. F.S. Blanton Collr.”; VMC • 1 đ̊; "Soberania Nac. PQ. 15-24 Feb 1999. J.E. Wappes”; TAMU.

\section{Type locality}

Panama, Panama, Cerro Campana.

\section{Description}

Major male (holotype)

Length $19.3 \mathrm{~mm}$.

HEAD. Clypeus bidentate, black on anterior margin, bright metallic red, with green sheen on posterior portion, roughened sculpture. Genae bright metallic red, with green sheen; roughened sculpture. Front black, bright metallic red on portions adjacent to cephalic horn. Cephalic horn black, curved posteriorly over pronotum (Figs $2 \mathrm{H}, 10 \mathrm{~A}$ ).

Pronotum. Uniformly black, with bright metallic red sheen, becoming completely black posteriorly and on lateral margins of posterolateral angles. Keel absent in the middle of anterior pronotal margin. Disc triangular, flat, with two weakly developed, elongate tubercles on anterior portion. Triangle smooth; scabriculous; impunctate. Sides with smooth sculpture; scabriculous; with almost effaced punctures. Lateral lines of pronotal triangle straight. Posterolateral angles weakly developed, widened, slightly projected posteriorly. Lateral fossae distinctly impressed. Basal fossae obtusely oval, distinctly impressed. Posterior margin impunctate (Figs 2H, 10A).

ElYTRA. Fine striae, smooth, dull black, with dark metallic blue sheen; impressed basally as distinct fossae, scabriculous, with almost effaced to effaced punctation. Interstriae black, smooth, scabriculous, impunctate. Sutural margin without apical tooth (Fig. 10A).

Protibiae. Quadridentate with apical spine.

TERGITE VIII. Bright metallic red, with green sheen, scabriculous; with rough, almost completely effaced punctures. Basal margin with thick, small setae.

Genitalia. Right lobe of endophallite copulatrix more developed than left lobe. Right lobe obtusely triangular in shape, rounded superiorly, and weakly developed. Left lobe bent posteriorly. Central ridge and column similar in size (Fig. 1L). 


\section{Minor male}

Like the major male, except for the reduction of the secondary sexual characters (i.e., cephalic horn, pronotal triangle and tubercles, and pronotal posterolateral angles). Occasionally, the pronotal disc is completely bright metallic red, with green sheen.

\section{Female}

Similar to the male, except for the head showing a cephalic trituberculate carina; with weakly developed tubercles; carinate middle tubercle, slightly more frontally projected than lateral tubercles; frons with distinctly impressed punctures; pronotal sculpture completely smooth, with superficially impressed punctures; pronotum almost completely dull black in the central portion, laterally and posteriorly bright metallic red with metallic green sheen; pronotal process trituberculate, lacking concavities; pronotal tubercles rounded, nearly aligned, well-spaced; with middle tubercle more developed than lateral tubercles; posterior pronotal midline almost completely effaced (Fig. 10B).

\section{Variation}

Mean length $17.8 \mathrm{~mm}(14.6-21.1 \mathrm{~mm})$. Colour variation was not found.

\section{Distribution}

Panama and north-Caribbean Costa Rica (Fig. 16). The distributions of $P$. panamensis sp. nov., $P$. malyi and $P$. pyrois show large areas of sympatry. Nevertheless, all these species are easily recognized.

\section{Remarks}

Phanaeus panamensis sp. nov. has frequently been confused with $P$. olsoufieffi by previous authors (Edmonds 1994; Arnaud 2002b; Edmonds \& Zídek 2012, Solís \& Kohlmann 2012; Kohlmann et al. 2018). Minor males and females of both species are strongly mimetic. More specimens from western

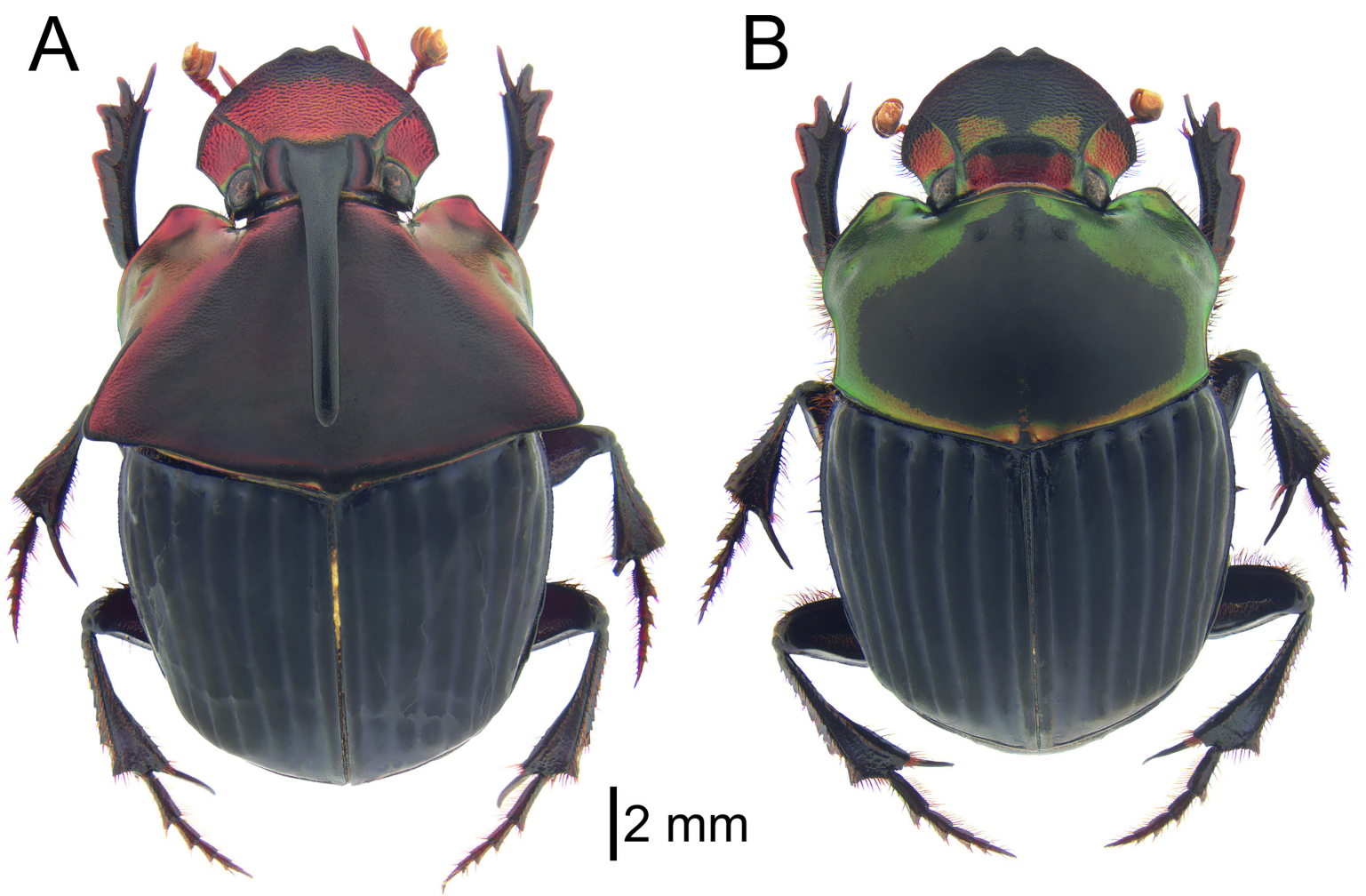

Fig. 10. Phanaeus panamensis sp. nov. A. Holotype, $\widehat{\partial}$ (TAMU). B. $\uparrow$ (TAMU). 
Panama and northern Colombia are needed to be revised in order to determine if P. olsoufieffi and P. panamensis sp. nov. are sympatric.

Phanaeus porioni Arnaud, 2001 stat. rev.

Figs $1 \mathrm{M}, 2 \mathrm{I}, 11,15,18 \mathrm{~N}, 19 \mathrm{~N}$

Phanaeus (Notiophanaeus) endymion porioni Arnaud, 2001: 4.

Phanaeus (Notiophanaeus) endymion porioni - Arnaud 2002b: 94 (as subspecies of P. endymion).

Phanaeus endymion porioni - Arnaud 2002b: 95 (as subspecies of P. endymion). - Krajcik 2006: 150 (as subspecies of $P$. endymion). — Edmonds \& Zídek 2012: 1, 8, 13 (as synonym of $P$. endymion).

Non Phanaeus (Notiophanaeus) endymion (error) - Edmonds 1994: 2, 8-9, 12, 19, 36, 39, 41-46, 54, 74, 101, figs 17, 209, 215-216, 221 (in part). — Edmonds \& Zídek 2012: 3, 13, figs 132-133, 136, 140, 143, 152-155 (in part).Phanaeus porioni - Edmonds \& Zídek 2012: 3, 6 (as synonym of P. endymion).

Non Phanaeus endymion (error) - Creedy \& Mann 2011: 34, 51. — Edmonds \& Zídek 2012: 1, 5-6 (in part).

\section{Diagnosis}

Phanaeus porioni and P. endymion are closely related, but the former is easily separated by the major female with the pronotal process weakly or not concave posteriorly and pronotal tubercles nearly aligned (Fig. 11B), while the males are distinguished by the endophallite copulatrix (Fig. 1). Additionally, P. porioni is recognized by the elytral striae always distinctly punctate (Fig. 11), but the strial surface never roughened as in P. pacificus sp. nov. (Fig. 9) and P. jackenioi sp. nov. (Fig. 6).

\section{Type material}

Holotype (studied from photographs, 1 ๙)

HONDURAS • đે, Arnaud 2001: 4 (Fig. 11C); Atlántida, Rco Bonito; "Phanaeus endym. porioni P.ARNAUD DET 2001 HOLOTYPE $\widehat{\jmath} /$ HONDURAS -ATLANTIDA, Rco Bonito $(250 \mathrm{~m})$, juilliet-1995, Thierry PORION Leg"; CPFA.

\section{Paratypes revised $(1 \hat{O}, 1$ \&)}

HONDURAS - Atlántida • 1 đ, 1 क; " "Rco Bonito (250 m), juilliet-1995, Thierry Porion Leg"; VMC.

Non-type material revised $(14 \hat{\partial} \hat{\partial}, 9$ $q$ $\rho)$

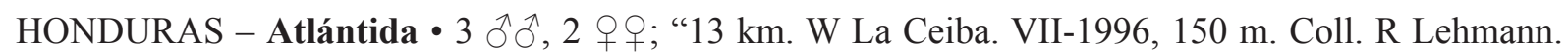
Flight intercept trap in cocoa plantation"; TAMU • 1 \%; same collection data as for preceding; UVGC •

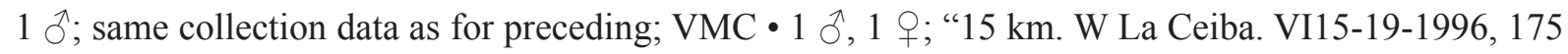

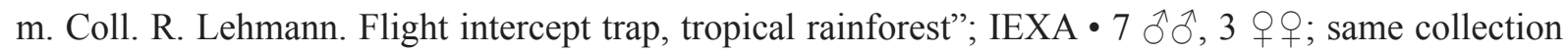
data as for preceding; TAMU $\bullet 1 \hat{\jmath}$ same collection data as for preceding; UVGC $\bullet 1 \hat{\jmath}, 2$ 우; same collection data as for preceding; VMC.

\section{Type locality}

Honduras, Atlántida, Rco Bonito. 


\section{Redescription}

Major male

HEAD. Clypeus bidentate, black anteriorly, dark metallic blue, green or blue-green posteriorly; roughened sculpture. Genae dark metallic blue, green or blue-green, with roughened sculpture. Front black. Cephalic horn black, curved posteriorly over pronotum (Figs 2I, 11A).

Pronotum. Keel absent in the middle of anterior pronotal margin. Disc triangular, flat, with two distinctly developed tubercles on anterior portion. Triangle uniformly dark metallic blue, green, or bluegreen; becoming black on posterior margin and beneath the posterolateral angles, lightly granulate, scabriculous, impunctate. Sides dark metallic blue, green, or blue-green; smooth sculpture, scabriculous, with superficially impressed punctures. Lateral lines of pronotal triangle straight. Posterolateral angles widened or acute, projected posteriorly. Lateral fossae distinctly impressed. Basal fossae obtusely oval, distinctly impressed. Posterior margin with superficially impressed punctures (Figs 2I, 11A).

ELYTRA. Striae fine, smooth, scabriculous, impressed basally as distinct fossae; dark blue, green, or bluegreen; always with distinctly impressed punctation. Interstriae black, smooth, scabriculous, with almost effaced punctures. Sutural margin without apical tooth (Fig. 11A).

Protibiae. Quadridentate with apical spine.

TERGITE VIII. Dark metallic blue, green, or blue-green; scabriculous; with rough, superficially impressed punctures. Basal margin with setae variable in size.

GeNITALIA. Right and left lobes of endophallite copulatrix similar in size. Right lobe obtusely triangular in shape, weakly developed superiorly. Left lobe obtusely lobed, strongly developed. Central ridge less developed than central column (Fig. 1M).

\section{Minor male}

Like the major male, except for the reduction of the secondary sexual characters (i.e., cephalic horn, pronotal triangle and tubercles, and pronotal posterolateral angles).

\section{Female}

Similar to the male, except for the head showing a cephalic trituberculate carina; with weakly developed, nearly aligned tubercles; carinate middle tubercle slightly more developed than lateral tubercles; frons with distinctly impressed punctures; pronotal sculpture smooth, with almost completely effaced punctures; pronotum almost completely black, becoming dark metallic blue, green, or blue-green posteriorly and laterally; pronotal process trituberculate, weakly concave posteriorly; pronotal tubercles nearly aligned; with rounded to dentiform middle tubercle, more developed than lateral tubercles; lateral tubercles rounded; posterior pronotal midline almost completely effaced (Fig. 11B).

\section{Variation}

Mean length $17 \mathrm{~mm}(13.1-20.1 \mathrm{~mm})$. Colour variants were not found.

\section{Distribution}

Caribbean Honduras, Belize, and probably north-Caribbean Guatemala (Fig. 15).

\section{Remarks}

Phanaeus porioni was considered as a synonym of P. endymion by Edmonds \& Zídek (2012). Nevertheless, differences in external and genital morphology were found by us. As a consequence, P. porioni is resurrected from previous synonymy and full species status is given to it. Apparently, a significant area of sympatry is found between P. endymion and P. porioni. The males of both species are strongly mimetic, but females are easily diagnosed by external morphology. The endophallite copulatrix will help to confidently separate males of both species (Fig. 1). We were not able to study any specimens of $P$. porioni from Belize. 


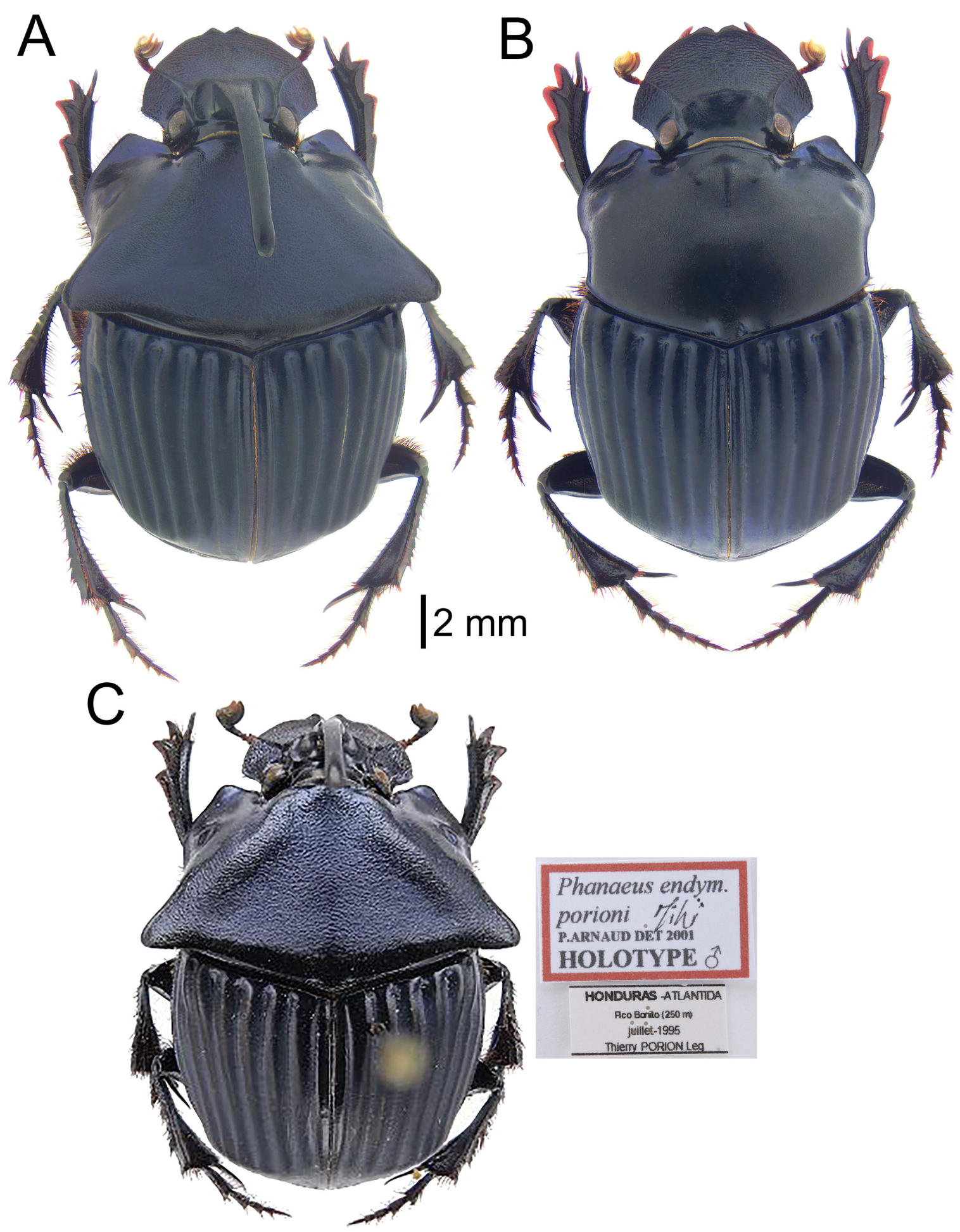

Fig. 11. Phanaeus porioni Arnaud, 2001 stat. rev. A. $\widehat{\partial}$ (TAMU). B. $q$ (TAMU). C. Holotype, $\widehat{\jmath}$ (by Patrick Arnaud) (CPFA). 
Phanaeus pyrois Bates, 1887

Figs 1N, 2J, 12, 16, 18O, $19 \mathrm{O}$

Phanaeus pyrois Bates, 1887: 58, pl. 2, table 3, figs 22-23 (in part).

Phanaeus pyrois - Nevinson 1982: 6 (in part). — Gillet 1911: 85 (in part). — Olsoufieff 1924: 37, 93, 152 (in part). — Blackwelder 1944-1957: 210 (in part). — Edmonds 1972: 830 (in part); 1979: 103 (in part); 1994: 3, 5, 8-9, 39, 44-46, 103 (in part). - Howden \& Young 1981: 134, 136 (in part). - Krajcik 2006: 152 (in part). - Price 2007: 17, figs 52-53, 54 (in part); 2009: 145 (in part). — Solís \& Kohlmann 2012: 1, 8-10, 31, fig. 1 (in part). — Edmonds \& Zídek 2012: 1, 5-6, 8, 13 (in part). — Moctezuma \& Halffter 2017: 55 (in part). — Moctezuma et al. 2017: 114, 130 (in part). — Kohlmann et al. 2018: 69, 78-79, 83, 88, 89, fig. 8a, d (in part). — Chamorro et al. 2019: 220 (in part).

Phanaeus (Notiophanaeus) pyrois - Edmonds 1994: 2, 8, 41, 44, figs 210, 214-215, 221 (in part). Arnaud 2002b: 96 (in part). — Edmonds \& Zídek 2012: 3, 13, figs 138, 142-143, 156-159 (in part). Phanaeus (Notiophanaeus) pyrois pyrois - Arnaud 2002b: 96 (in part).

Phanaeus pyrois pyrois - Arnaud 2002b: 97 (in part).

\section{Diagnosis}

Easily diagnosed species by the pronotum bright metallic red (Figs 12A, D), green (Fig. 2J) or dark metallic blue (12B), with elytral striae not strongly impressed basally (Fig. 12). The rest of the green/ blue species of the $P$. endymion species group are recognized by the elytral striae strongly impressed basally as a distinct fossa. A black dorsal colour is never found in P. pyrois specimens. Minor males of P. panamensis sp. nov. and red P. pyrois may be strongly mimetic, but easily separated by the endophallite copulatrix (Fig. 1).

\section{Type material}

Lectotype (studied from photographs, 1 )

NICARAGUA - Chontales • $\hat{O}$, Edmonds 1994: 45 (Fig. 12D); "NHMUK 013678267/B. C. A. p. 58, sp.8./LECTO-TYPE/Phanaeus pyrois Bates. LECTOTYPE $\curvearrowright$ P. ARNAUD DET 1980/T. Belt/Type/ P. pyrois đ̂/ Sp. figured"; NHMUK 013678267; BMNH.

\section{Non-type material revised $(7 \hat{\partial} \widehat{\partial}, 4 \stackrel{+}{\rho})$}

NICARAGUA - Granada • 1 đ̊; "Volcán Mombacho. Bosque Seco. 30-VI-98. JM. Mars"; TAMU • 1 đ̊; "Volcán Mombacho. Santa Ana. 21-V-98. Malaise. JM. Mars"; VMC • 1 đ; "Volcán Mombacho. El Progreso. 30-VI-98. JM. Mars”; IEXA. - Jinotega • 1 đ’; “El Jaguar Coffee Finca. XII-3-8-2005. 4356 ft. D. G. Marqua"; TAMU • 2 क क; "El Jaguar Coffee Finca. VI-5-10-2005, el. 4,356 ft. Coll. D.

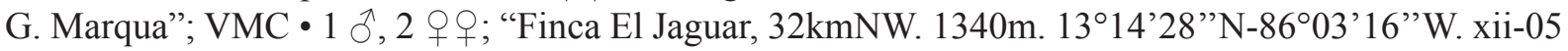
col D.G. Marqua"; TAMU 1 1 ; ; same collection data as for preceding; VMC.

COSTA RICA - Cartago • 1 đ̊; “Turrialba. 650m. 26.Feb.1980. H \& A Howden”; TAMU.

\section{Type locality}

Nicaragua, Chontales.

\section{Redescription}

\section{Major male}

HEAD. Clypeus bidentate, black anteriorly, bright metallic red, green, or dark metallic blue posteriorly; roughened sculpture. Genae bright metallic red, green, or dark metallic blue; roughened sculpture. Front 
black, bright metallic red, green, or dark metallic blue on portions adjacent to cephalic horn. Cephalic horn black, curved posteriorly over pronotum (Figs 2J, 12A-B, D).

Pronotum. Keel absent in the middle of anterior pronotal margin. Disc triangular, flat, with two distinctly developed tubercles on anterior portion. Triangle bright metallic red, green, or dark metallic blue; becoming black on posterior margin of posterolateral angles; lightly granulate, scabriculous, impunctate. Sides bright metallic red, green, or dark metallic blue; smooth sculpture, scabriculous, with superficially impressed punctures. Lateral lines of pronotal triangle straight. Posterolateral angles widened or slightly acute; projected posteriorly or posterolaterally. Lateral fossae distinctly impressed. Basal fossae obtusely oval, distinctly impressed. Posterior margin sometimes black, with superficially impressed to effaced punctures (Figs 2J, 12A-B, D).

ELYTRA. Striae fine, smooth, scabriculous, not strongly impressed basally; bright red, green, or dark blue; with superficially impressed punctation. Interstriae black, smooth, scabriculous, with almost effaced to effaced punctures. Sutural margin without apical tooth (Fig. 12A-B, D).

Protibiae. Quadridentate with apical spine.

TERGITE VIII. Bright metallic red, green, or dark metallic blue; scabriculous; with rough, superficially impressed punctures. Basal margin with setae variable in size.

GenitaLia. Right and left lobes of endophallite copulatrix similar in size. Right lobe strongly reduced, obtusely triangular in shape; rounded superiorly. Left lobe obtusely lobed, strongly developed. Central ridge and column similar in size (Fig. 1N).

\section{Minor male}

Like the major male, except for the reduction of secondary sexual characters (i.e., cephalic horn, pronotal triangle and tubercles, and pronotal posterolateral angles).

\section{Female}

Similar to the male, except for the head showing a cephalic trituberculate carina; with conical, nearly aligned tubercles; middle tubercle slightly more developed than lateral tubercles; frons with distinctly impressed punctures; pronotal sculpture smooth, with almost effaced punctures; pronotum almost completely black, becoming posteriorly and laterally bright metallic red, green, or dark metallic blue; pronotal process trituberculate, lacking concavity; pronotal tubercles nearly aligned; with middle tubercle more developed than lateral tubercles; posterior pronotal midline superficially impressed (Fig. 12C).

\section{Variation}

Mean length $17.8 \mathrm{~mm}(14.7-20.1 \mathrm{~mm})$. Phanaeus pyrois is the most variable in colour species of the $P$. endymion species group. The outspoken colour variability of this species was previously outlined by Bates (1886-1889), particularly for the specimens from Nicaragua. Tree typical chromatic morphs were found by us (bright metallic red, Fig. 14A, D; green, Fig. 2J; or dark metallic blue, Fig. 12B), but colour combinations are found and rare specimens has a bright golden sheen.

\section{Distribution}

Nicaragua and north-Caribbean Costa Rica (Fig. 16). The distributions of P. pyrois and P. panamensis sp. nov. show an important sympatry area in north Caribbean Costa Rica.

\section{Remarks}

Phanaeus pyrois and several closely related species were incorrectly lumped together by previous authors (Howden \& Young 1981; Edmonds 1994; Edmonds \& Zídek 2012; Solís \& Kohlmann 2012; Chamorro 

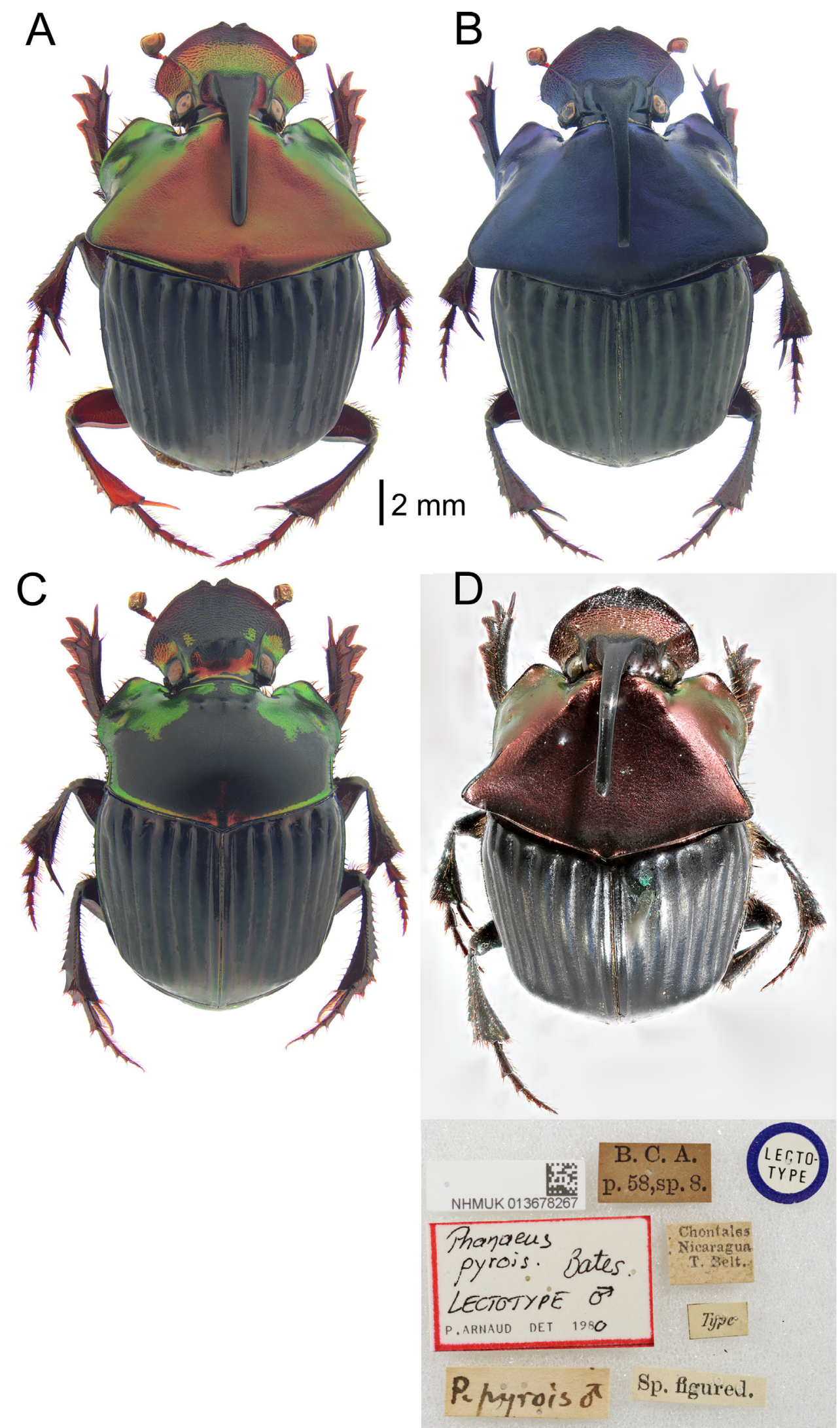

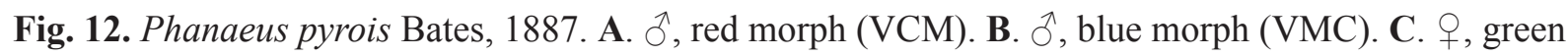
morph (TAMU). D. Lectotype, $\widehat{o}$ (by Mario Cupello, Universidade Federal do Paraná, Brazil) (BMNH). 
et al. 2018, 2019; GBIF Secretariat 2019b). Differences in body colour and the pronotal, elytral and genital morphology were found to confidently diagnose $P$. pyrois and all the closely related species. The blue chromatic morph of $P$. pyrois (Fig. 12B) was suggested by Edmonds (1994) to be a hybrid with P. endymion. Nevertheless, blue specimens of P. pyrois (Fig. 12B) do not share the diagnostic characters with $P$. endymion (Figs 1D, 2B, 4). As a consequence, there is no evidence to consider a hybridization between $P$. endymion and P. pyrois. Edmonds \& Zídek (2012) suggested that doubtful specimens of "viridicollis" (Figs 2J, 12C) were collected in Nicaragua along with "normal" P. pyrois. After revising the doubtful specimens of "viridicollis" from Nicaragua (Figs 2J, 12C), we disagree with Edmonds \& Zídek (2012) and conclude that they incorrectly referred to the green chromatic morph of P. pyrois as $P$. viridicollis.

Phanaeus rzedowskii sp. nov. urn:1sid:zoobank.org:act:A98B849A-4240-4DD3-9997-D0B3CB7B00C2

Figs $1 \mathrm{O}, 2 \mathrm{~K}, 13,15,18 \mathrm{P}, 19 \mathrm{P}$

\section{Diagnosis}

This is the only species within the P. endymion species group where major males show a pronotal disc with a superficially impressed midline (Fig. 2K).

\section{Etymology}

We are honoured to name the new species after Jerzy Rzedowski, to recognise his outstanding contribution to the knowledge of the Mexican biodiversity, particularly to the flora from El Bajío region.

Tyepa material $(2 \hat{\jmath}, 2$ q +$)$

Holotype

MEXICO - Michoacán • đ̂; “Coalcoman. 24-VII-90. Fungus. Terry Taylor col”; TAMU.

Paratypes

MEXICO - Michoacán • 1 q; same collection data as for holotype; TAMU • 1 ภ, 1 \&; "Villa Victoria. 31-VIII-95. 1550 m"; VMC.

\section{Type locality}

Mexico, Michoacán, Coalcomán.

\section{Description}

Major male (holotype)

Length $18 \mathrm{~mm}$.

HEAD. Clypeus bidentate, black on anterior margin, dark metallic blue-green on posterior portion, roughened sculpture. Genae dark metallic blue-green, with roughened sculpture. Front dark metallic blue-green on portions adjacent to cephalic horn. Cephalic horn black, curved posteriorly over pronotum (Figs 2K, 13A).

Pronotum. Uniformly dark metallic blue-green, becoming completely black on and beneath lateral margins of posterolateral angles, and on posterior margin. Keel absent in the middle of anterior pronotal margin. Disc triangular, flat, with two distinctly developed tubercles on anterior portion. Triangle lightly granulate, with midline superficially impressed, scabriculous, impunctate. Sides with smooth sculpture, scabriculous, with superficially impressed punctures. Lateral lines of pronotal triangle straight. Posterolateral angles sharply acute, projected posteriorly. Lateral fossae distinctly impressed. Basal 
fossae obtusely oval, distinctly impressed. Posterior margin with superficially impressed punctures (Figs 2K, 13A).

ELYTRA. Fine striae, dark blue-green, with superficially impressed punctures, scabriculous, impressed basally as distinct fossae. Interstriae black, scabriculous, partially roughened, with superficially impressed punctures. Sutural margin without apical tooth (Fig. 13A).

Protibiae. Quadridentate with apical spine.

TERGITE VIII. Dark metallic blue-green, scabriculous; with rough, superficially impressed punctures. Basal margin with setae variable in size.

Genitalia. Right lobe of endophallite copulatrix more developed than left lobe. Right lobe obtusely triangular in shape, sharply acute frontally, rounded superiorly. Left lobe strongly developed, obtusely lobed. Central ridge more developed than central column (Fig. 1O).

\section{Minor male}

Unknown.

\section{Female}

Similar to the male, except for the head showing a cephalic trituberculate carina; with almost aligned, conical tubercles, similar in size tubercles; frons distinctly impressed, rough punctures; pronotal sculpture completely smooth, with superficially impressed punctures; colour of pronotum as in P. endymion; pronotal process trituberculate, posteriorly concave; dentiform middle tubercle, strongly developed, more frontally projected than lateral tubercles; almost completely reduced lateral tubercles (Fig. 13B).

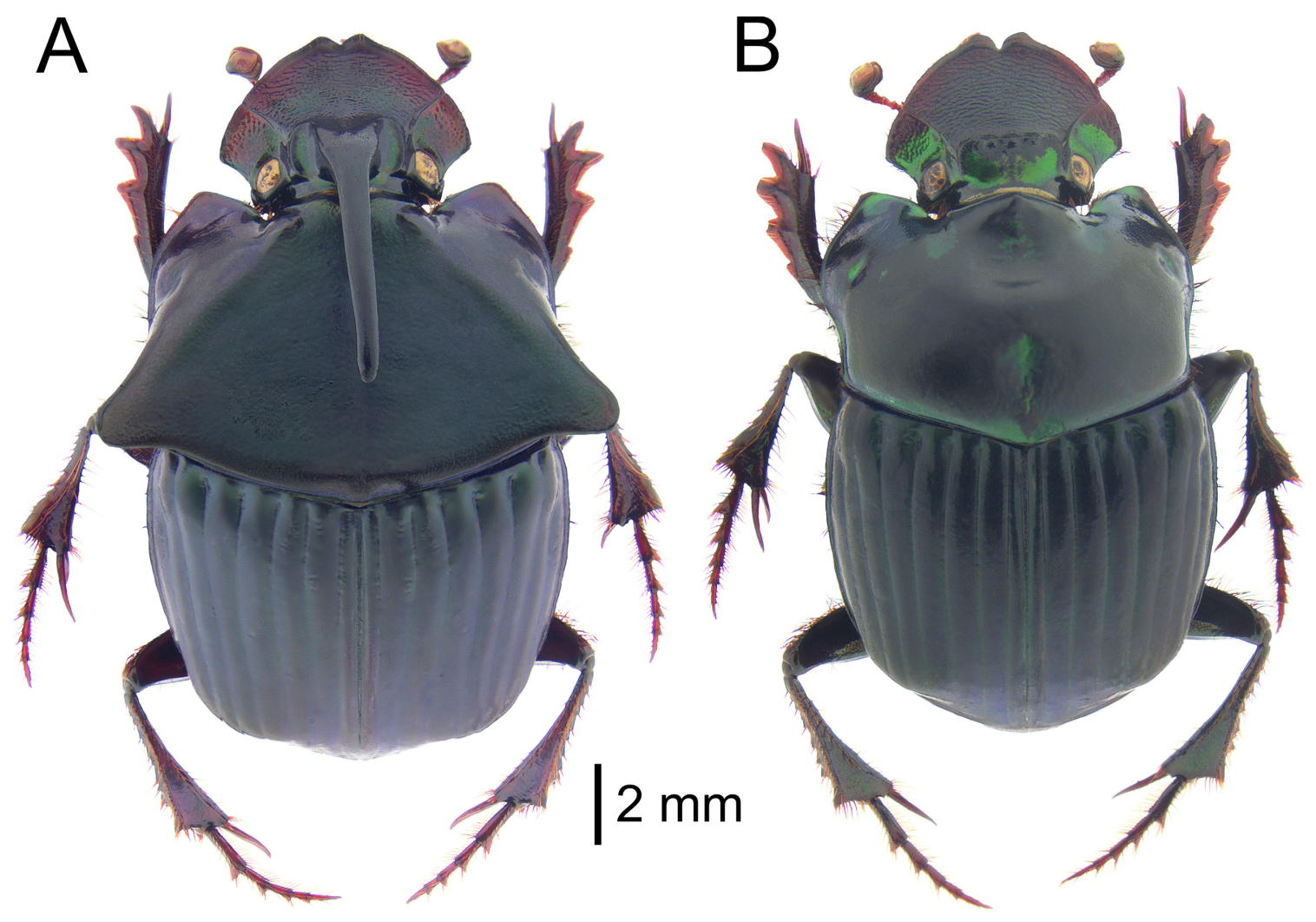

Fig. 13. Phanaeus rzedowskii sp. nov. A. Holotype, $\widehat{\jmath}$ (TAMU). B. $\uparrow$ (VMC). 


\section{Variation}

Mean length $17.4 \mathrm{~mm}(16.5-18.2 \mathrm{~mm})$. Chromatic variation was not observed in the type series.

\section{Distribution}

Sierra Madre del Sur, southern Michoacán (Fig. 15).

\section{Remarks}

This new species was previously confused with P. endymion (Edmonds 1994). Nevertheless, the distribution areas for P. endymion and P. rzedowskii sp. nov. are completely different, and they are easily recognized by external and genital morphology.

\section{Phanaeus zapotecus Edmonds, 2006}

Figs 1P, 2L, 14-15, 18Q, 19Q

Phanaeus zapotecus Edmonds, 2006: 31-32, 35-37, figs 1, 3, 5, 7.

Phanaeus dionysius Kohlmann et al., 2018: 67-70, 76, 78, 82, 88-89, figs 1b, 3a-b, d, 4-7. Syn. nov.

Phanaeus zapotecus - Edmonds \& Zídek 2012: 1, 7-8. — Moctezuma \& Halffter 2017: 52, 54-55, fig. 23. - Moctezuma et al. 2017: 114, 130, 132; 2019: 253.

Phanaeus (Notiophanaeus) zapotecus - Edmonds \& Zídek 2012: 3, 13, figs 139, 141, 143, 148-151.

Phanaeus (Notiophanaeus) dionysius - Kohlmann et al. 2018: 68, 70.

Non Phanaeus endymion - Edmonds 1994: 44 (referred to as "Oaxaca" population).

Non Phanaeus (Notiophanaeus) "Oaxaca" endymion - Edmonds 1994: fig. 221.

Type material of Phanaeus zapotecus revised ( $3 \widehat{\partial}, 5$ \& + )

Holotype (not studied, temporarily lost)

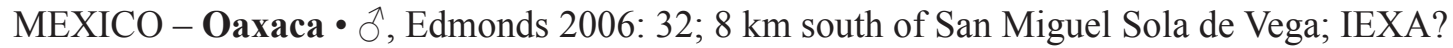

\section{Paratypes}

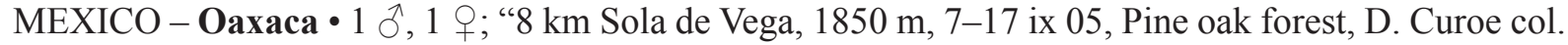

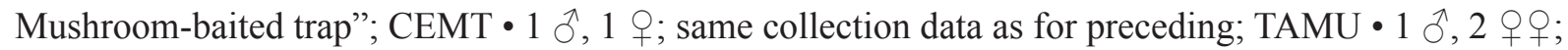
same collection data as for preceding; VMC • 1 क; " $8 \mathrm{~km}$ Sola de Vega, $1850 \mathrm{~m}, 4-9$ vii 05, Pine oak forest, D. Curoe col. Mushroom-baited trap"; TAMU.

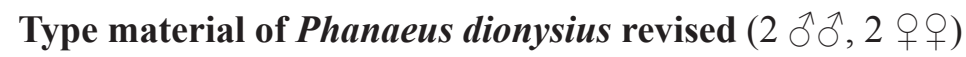

Holotype

MEXICO - Oaxaca - "La mesita San Pablo Etla, 23-VI-17, coprotrampa, x- 9644’18.91”O, y179'54.36”N, bosque de Encino, 1976 m, Arriaga A. \& Arenas A. Col.”; IEXA.

\section{Paratypes}

MEXICO - Oaxaca • 2 + $q$; same collection data as for holotype; IEXA 1 ô; "La mesita San Pablo

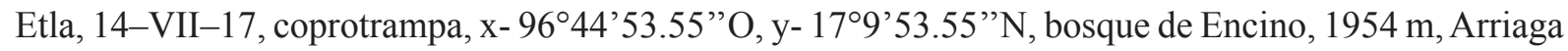
A. \& Arenas A. Col."; IEXA.

\section{Non-type material revised $(1$ $)$}

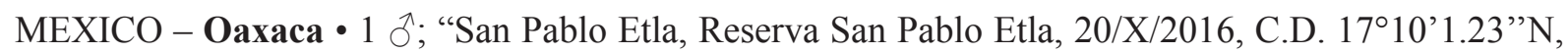
9644'14.25”O, 1994 m, Alfosina Arriaga Col.”; VMC. 


\section{Type locality}

Mexico, Oaxaca, $8 \mathrm{~km}$ south of San Miguel Sola de Vega.

\section{Phanaeus dionysius}

Kohlmann et al. (2018) recently described P. dionysius based upon specimens from San Pablo Etla, Oaxaca, Mexico and suggested that $P$. zapotecus and $P$. dionysius were sister taxa. The following character combination helps to separate both species according to Kohlmann et al. (2018): P. dionysius has long and slender pronotal posterolateral angles, whereas $P$. zapotecus has short and rounded posterolateral angles. The basal border of the tergite VIII in $P$. dionysius forms a small indentation at its middle, whereas it runs completely straight in $P$. zapotecus. Additionally, the apex of the parameres of $P$. dionysius is more projected, than that from P. zapotecus. Moreover, the middle sinuation of the parameres in lateral view is much more pronounced in $P$. dionysius. Nevertheless, we consider that the description and diagnosis of $P$. dionysius exemplify some of the frequent problems occurring in taxonomical work (Komarek \& Beutel 2006) as follows.

\section{Insufficient study of types}

Kohlmann et al. (2018) did not indicate how many specimens of $P$. zapotecus they revised, but they commented that the paratypes housed at CNIN were checked by them. Taking into account this information and the original description of P. zapotecus (Edmonds 2006), we assume that Kohlmann et al. (2018) revised two paratypes at most.

\section{Insufficient assessment of the range of character variation}

Kohlmann et al. (2018) were not able to adequately assess the morphological variation of P. zapotecus, as a consequence of the reduced number of paratypes studied by them. The pronotal posterolateral angles were found by us to be long and slender in some paratype major males of P. zapotecus (Fig. 14A). The basal border of the tergite VIII is highly variable: four paratypes of P. zapotecus revised by us show the small indentation at the middle of the basal border of the tergite VIII (Fig. 14D), whereas it runs completely straight in two paratypes. The small indentation is present in the basal border of the tergite VIII of three specimens of $P$. dionysius revised by us, whereas it runs completely straight in two paratypes (Fig. 14E).

Kohlmann et al. (2018) illustrated the endophallite copulatrix of $P$. dionysius (available from https://zookeys.pensoft.net/article/23029/zoom/fig/13/) but they overlooked its comparison with P. zapotecus (Fig. 1P). We noticed that the morphology of both P. zapotecus (Fig. 1P) and $P$. dionysius is identical when we compared the endophallites under the microscope. Furthermore, the endophallite copulatrix of the holotype of $P$. dionysius has suffered deformation and abrasion, maybe as a result of the preparation methods (soaking for $5 \mathrm{~min}$ in a solution of $5 \%$ boiling $\mathrm{KOH}$ ) and/or storage (dry preservation in a plastic microvial). This structure was not found by us to be stored in a microvial with glycerol as mentioned by Kohlmann et al. (2018). The morphology of the cephalic carina and the pronotal tubercles of the females of P. zapotecus (Fig. 14B) and P. dionysius (see https://zookeys.pensoft.net/article/23029/zoom/fig/14/) did not differ. Moreover, the body colour in the paratypes of $P$. zapotecus varied from jet black or bright dark blue to jet black with a green-blue sheen (Fig. 14A-C), falling within the variation of P. dionysius (Kohlmann et al. 2018).

Kohlmann et al. (2018) commented that a major male was designated as holotype. Nevertheless, we found out that the holotype of $P$. dionysius housed at IEXA is the minor male illustrated by Kohlmann et al. (2018) in the original description (available from https://zookeys.pensoft.net/article/23029/zoom/fig/15/). As a consequence, we assume that the original description of $P$. dionysius was not based on the holotype. We found that a paratype minor male of $P$. zapotecus (Fig. 14C) and the holotype of $P$. dionysius (https://zookeys.pensoft.net/article/23029/zoom/fig/15/) were morphologically almost identical. 

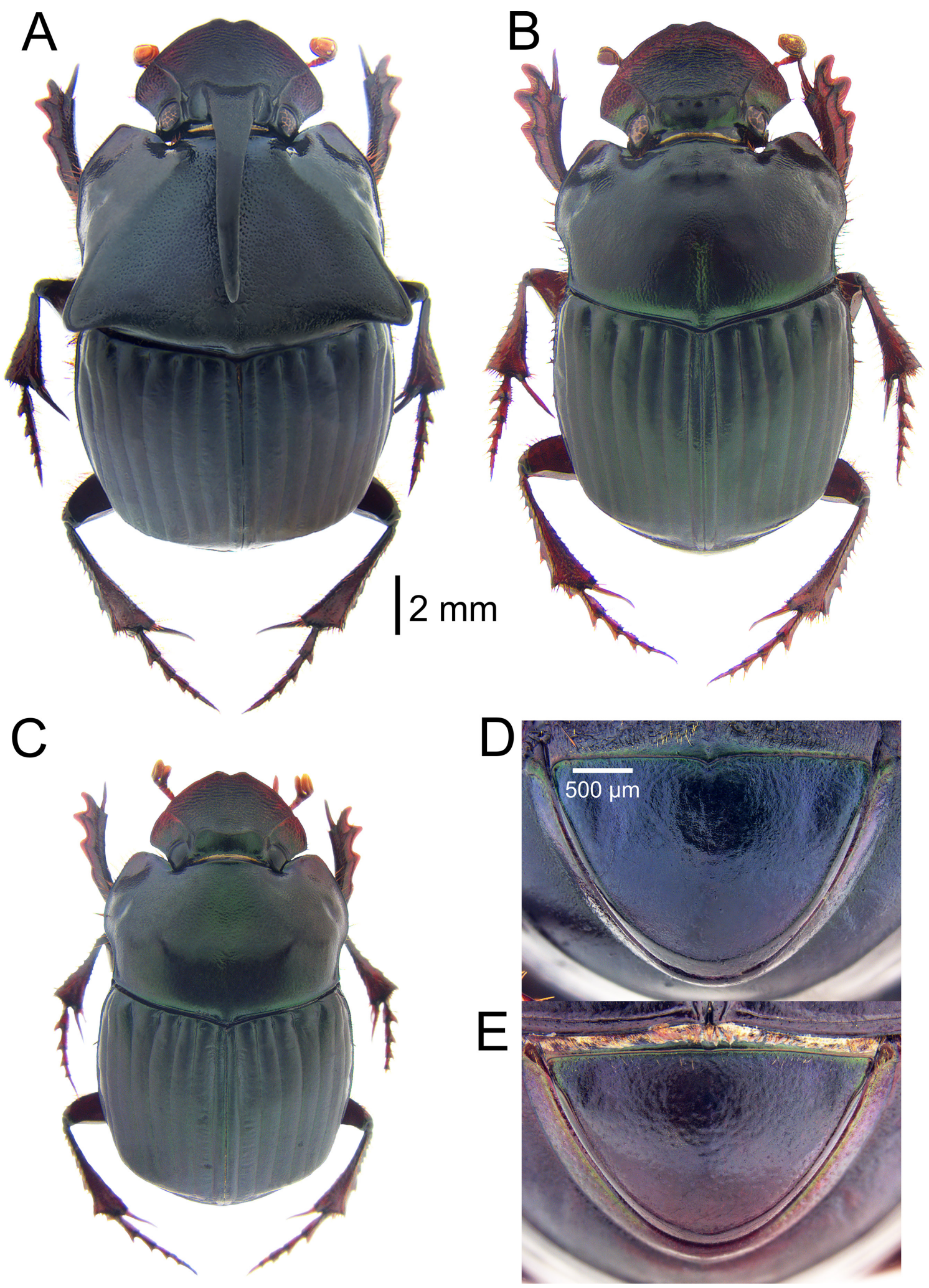

Fig. 14. A-D. Phanaeus zapotecus Edmonds, 2006. A. $\widehat{\jmath}$ (TAMU). B. $q$ (TAMU). C. Minor $\widehat{\partial}$ (VMC). D. Tergite VIII (TAMU). E. Phanaeus dionysius Kohlmann, Arriaga-Jiménez \& Rös, 2018 syn. nov., tergite VIII (IEXA). 
Characters not suitable for a study at a given taxonomic rank

The revision of a majority of species within the $P$. endymion species group led us to conclude that the morphology of the aedeagus is not taxonomically informative to separate species, as suggested by previous authors (Edmonds 1994; Price 1995; Arnaud 2002b; Moctezuma \& Halffter 2017; Moctezuma et al. 2017, 2019).

In the light of the findings presented herein, we conclude that the description and diagnoses provided by Kohlmann et al. (2018) do not justify the splitting of $P$. dionysius and P. zapotecus in two different species. As a consequence, a new junior subjective synonymy is recognized herein: Phanaeus zapotecus Edmonds, 2006 = Phanaeus dionysius Kohlmann, Arriaga-Jiménez \& Rös, 2018 syn. nov.

\section{Distribution}

Sierra Madre del Sur and Sierra Norte, central Oaxaca (Fig. 15).

\section{Remarks}

Mean length $16.4 \mathrm{~mm}(14.8-18.5 \mathrm{~mm})$. To the original description of this species, we add that the elytral striae are impressed basally as distinct fossae (Fig. 14); right lobe of endophallite copulatrix more developed than left lobe; right lobe obtusely triangular in shape, strongly developed superiorly; left lobe strongly reduced, lobed, slightly concave inferiorly; central ridge more developed than central column (Fig. 1P). For the female, the head shows a cephalic trituberculate carina; with almost aligned, conical tubercles; middle tubercle slightly more developed than lateral tubercles; frons with almost effaced punctures; pronotal process trituberculate, with posterior concavity; rounded pronotal tubercles; with middle tubercle slightly more developed than lateral tubercles; posterior pronotal midline distinctly impressed (Fig. 14B).

Edmonds (2006) commented that the holotype and three paratypes $(1 \hat{O}, 2$ q $q)$ of $P$. zapotecus were housed at IEXA. However, the type material was not found by us at IEXA in a recent search. Therefore, the holotype and these paratypes are considered temporarily lost. It is possible that the former collection manager of IEXA, Professor Miguel Angel Morón Ríos, knew the location of the holotype and paratypes of $P$. zapotecus, but, unfortunately, we were not able to confirm this assumption because of his recent death.

Phanaeus zoque Moctezuma \& Halffter, 2017

Figs 1Q, 15, 18R, 19R

Phanaeus zoque Moctezuma \& Halffter, 2017: 47, 48, 52, 55-56, figs 1-15, 23.

Phanaeus zoque - Moctezuma et al. 2017: 113-114, 126, 128, 131-132, fig. 19; 2019: 252-253, fig. 5. - Kohlmann et al. 2018: 83, 88.

\section{Type material}

Holotype

MEXICO • ô, Moctezuma \& Halffter 2017: 48 (revised); Oaxaca, Santa María Chimalapa, Chocomanatlán; IEXA.

\section{Type locality}

Mexico, Oaxaca, Santa María Chimalapa, Chocomanatlán (José López Portillo).

\section{Distribution}

Temperate mountains of Los Chimalapas, eastern Oaxaca and western Chiapas (Fig. 15). 


\section{Remarks}

Mean length $15.8 \mathrm{~mm}(13.2-18.4 \mathrm{~mm})$. To the original description we add the elytral striae impressed basally as distinct fossae; right and left lobes of endophallite copulatrix similar in size; right lobe obtusely triangular in shape, distinctly rounded superiorly; left lobe strongly developed, obtusely lobed; central ridge less developed than central column (Fig. 1Q). For the female, the head showing a cephalic trituberculate carina; with conical, similar in size tubercles; middle tubercle slightly more frontally projected than lateral tubercles; frons with almost effaced to effaced punctures; pronotal sculpture completely smooth, with almost effaced to effaced punctures; pronotal process trituberculate, with posterior concavity; with dentiform middle tubercle, strongly more developed and projected frontally than lateral tubercles; carinate or rounded lateral tubercles; posterior pronotal midline almost completely effaced.

After having described P. zoque (Moctezuma \& Halffter 2017), the following paratypes were deposited

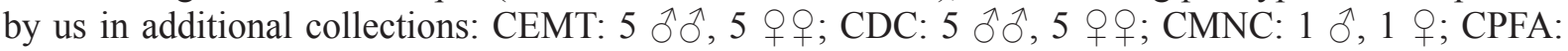

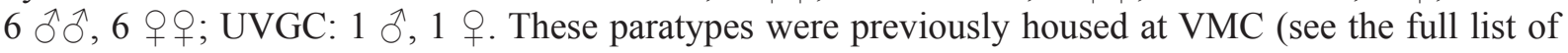
paratypes in Moctezuma \& Halffter 2017).

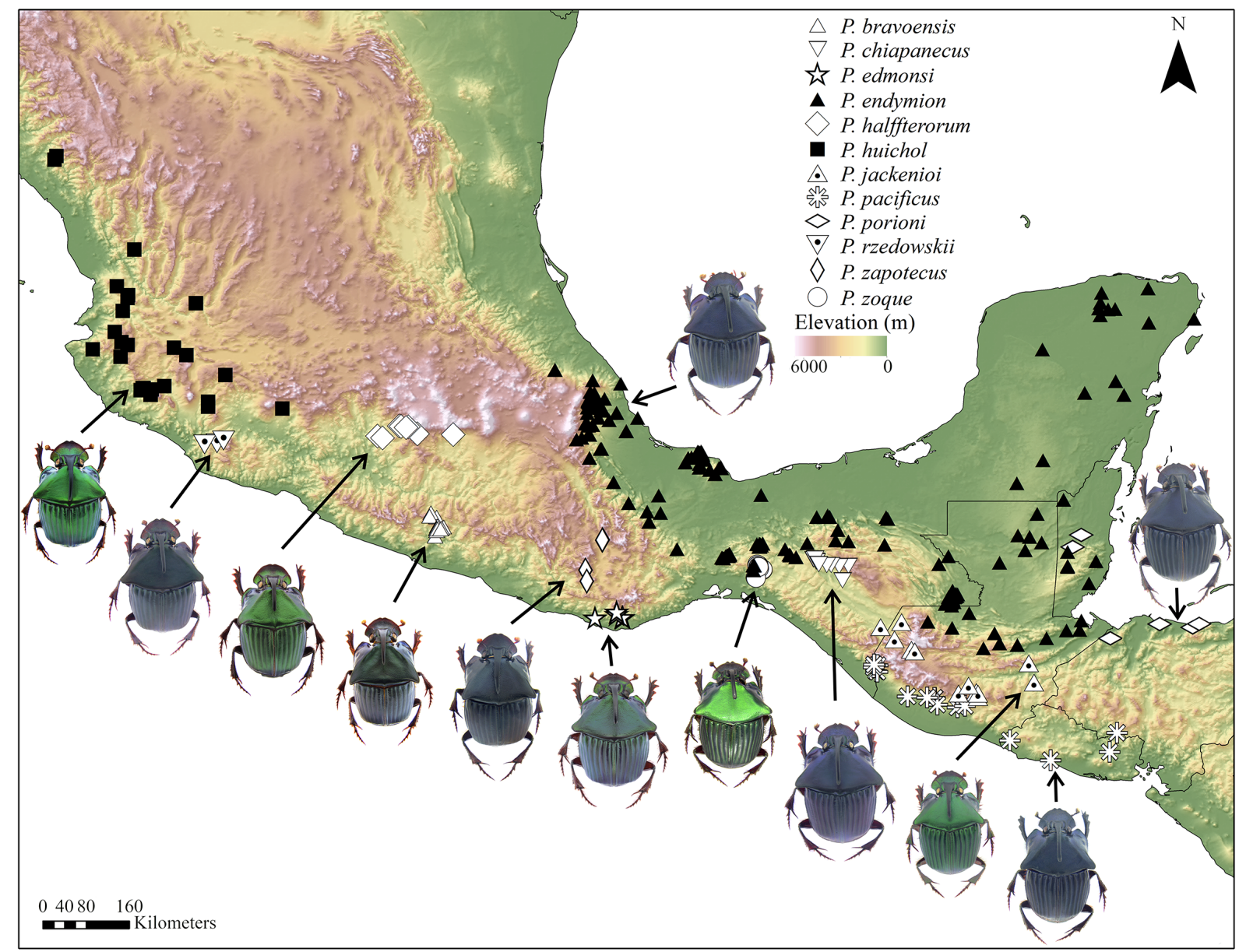

Fig. 15. Distribution of the Phanaeus endymion species group in North and Central America (in part). Phanaeus bravoensis Moctezuma, Sánchez-Huerta \& Halffter, 2017; P. edmondsi Moctezuma, Deloya \& Halffter, 2019; P. halffterorum Edmonds, 1979; and P. huichol Moctezuma, Sánchez-Huerta \& Halffter, 2017 by Jose Luis Sánchez-Huerta. 


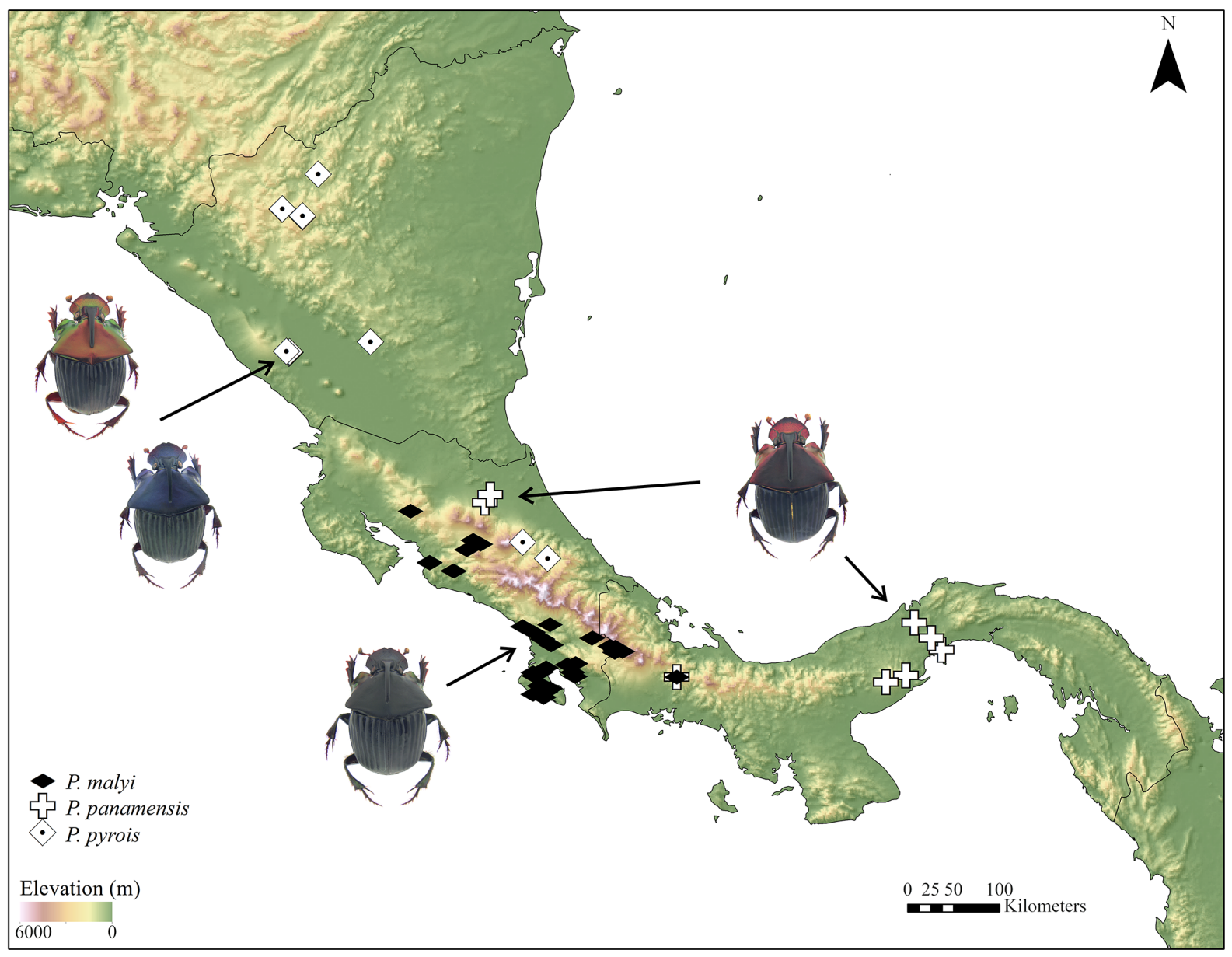

Fig. 16. Distribution of the Phanaeus endymion species group in Central America (in part).

\section{Key to species of the Phanaeus endymion species group}

1. Sutural margin of each elytron upturned to form a sharp ridge, which is progressively more elevated posteriorly and prolonged into a small, sharp tooth at apical angle; elytral margin slightly excised adjacent to this tooth.

- Sutural margin of elytra simple (running straight, not upturned)..... 3

2. Male with dentiform keel in the middle of anterior pronotal margin, lateral lines of pronotal triangle straight. Southern Mexico State and Morelos (Fig. 15). P. halffterorum Edmonds, 1979

- Male with keel absent in the middle of anterior pronotal margin, lateral lines of pronotal triangle curved. Sierra Madre del Sur, central Guerrero (Fig. 15)

P. bravoensis Moctezuma, Sánchez-Huerta \& Halffter, 2017

3. Pronotal disc of male evenly and densely but finely granulate, granules in most specimens larger and becoming squamose along lateral margins of disc and extending onto posterolateral angles; sides of pronotum strongly roughened (Figs $2 \mathrm{~L}, 14 \mathrm{~A}, \mathrm{C}$ ). Female pronotum slightly roughened; with distinctly impressed midline (Figs 14B, 18Q). Sierra Madre del Sur and Sierra Norte, central Oaxaca (Fig. 15)

- Pronotal disc of male lacking distinct granulation, or, if granules present, these are minute and restricted along lateral margins of disc; sides of pronotum smooth. Female pronotum smooth; with superficially impressed to completely effaced midline....... 
4. Elytral striae deeply punctate; all strial punctures forming a distinct fossa, giving a completely roughened surface to striae (Figs 1K, 2G, 9, 19L). Pacific slope of the Sierra Madre de Chiapas and El Salvador (Fig. 15).

P. pacificus sp. nov.

- Elytral striae distinctly punctate to impunctate. If strial punctures distinctly impressed, forming a distinct fossa giving a completely roughened surface to first and second striae, or strial punctures forming a distinct fossa giving a partially roughened surface to basal half of striae

5. Pronotum of female with anteromedial concavity bounded anteriorly by three variable on shape tubercles (Figs 4C, 11B, 13B, 18E, N, P).

- Pronotum of female evenly convex, lacking anteromedial concavity even in largest specimens, bearing three round, smooth tubercles in transverse line near anterior margin (Figs 3B, 5B, 6B, 7B, 8B, 10B, 12C, 18C, F, I-K, M, O).

6. Pronotum of female with concavity bounded anteriorly by a raised U- or V-shaped process; middle pronotal tubercle dentiform or rounded, always more developed and frontally projected than lateral tubercles; pronotal concavity interrupted posteriorly by a small rounded bump or strongly developed dentiform tubercle (Figs 4C, 13B, 18E, P). Endophallite copulatrix variable.

- Pronotum of female with concavity bounded anteriorly by three isolated, round, almost aligned tubercles; middle tubercle sometimes dentiform and more strongly developed than lateral tubercles (Figs 11B, 18N). Right and left lobes of endophallite copulatrix similar in size; right lobe obtusely triangular in shape, weakly developed superiorly; left lobe obtusely lobed, strongly developed; central ridge distinctly developed (Fig. 1M). Caribbean Honduras and Belize (Fig. 16)

P. porioni Arnaud, 2002 stat. rev.

7. Pronotal disc of male with superficially impressed midline (Fig. 2K). Right lobe of endophallite copulatrix more developed than left lobe; right lobe obtusely triangular in shape, sharply acute frontally, rounded superiorly; left lobe strongly developed, obtusely lobed; central ridge strongly developed (Fig. 1O). Sierra Madre del Sur, southern Michoacán (Fig. 15) ......P. rzedowskii sp. nov.

- Pronotal disc of male with completely effaced midline (Fig. 2B). Central ridge of endophallite copulatrix distinctly developed (Fig. 1D, G, Q)

8. Pronotum of male uniformly dark blue, dark metallic blue-green or dark metallic green (Figs $2 \mathrm{~B}$, 4A-B). Weakly developed keel close to anterior margin of pronotum, or keel completely effaced (Fig. 2b). Right lobe of endophallite copulatrix more developed than left lobe; right lobe obtusely triangular in shape; left lobe obtusely lobed inferiorly, obtusely triangular superiorly; central ridge less developed than central column (Fig. 1D). Lowlands and midlands of the Gulf of Mexico slope, Yucatán Peninsula, Belize, northern Guatemala (Fig. 15) P. endymion Harold, 1863

- Pronotum of male uniformly bright metallic green, bright metallic green-blue, sometimes showing a red or golden sheen. Keel always absent on anterior margin of pronotum. Endophallite copulatrix variable

9. Anterior metasternal angle obtuse in lateral view. Lateral metasternal angles well defined and slightly curved. Left lobe of endophallite copulatrix almost completely lobed (Fig. 1Q). Temperate mountains of Los Chimalapas, eastern Oaxaca and western Chiapas (Fig. 15)

P. zoque Moctezuma \& Halffter, 2017

- Anterior metasternal angle almost right angled but with rounded apex in lateral view. Lateral metasternal angles evanescent. Left lobe of endophallite copulatrix straight posteroinferiorly (Fig. 1G). Jalisco, northern Michoacán, Nayarit, southern Sinaloa (Fig. 15)

P. huichol Moctezuma, Sánchez-Huerta \& Halffter, 2017 
10. Elytral interstriae evenly convex and glossy midlongitudinally; striae impressed basally as distinct fossae (Figs 3, 6, 7, 18C, I-J)

- Elytral interstriae distinctly flattened and uniformly dull; striae not strongly impressed basally (Figs 5, 8, 10, 12, 18F, K, M, O)...

11. Almost completely bright black dorsally (Figs 2E, 7). Pacific slope of the Cordillera de Talamanca, Costa Rica and Panama (Fig. 16) P. malyi Arnaud, 2002

- Pronotum typically bright metallic green, blue-green or dark metallic blue (Figs 2A, D, 3, 6)..... 12

12. Distinctly developed keel on central anterior margin of pronotum of male; right lobe of endophallite copulatrix tapering superiorly and straight apically (Fig. 1C). Sierra Madre del Sur, southern Oaxaca (Fig. 15) .............................................................P. edmondsi Moctezuma, Deloya \& Halffter, 2019

- Always with keel absent on central anterior margin of pronotum of male (Fig. 2A, D). Endophallite copulatrix variable

13. Larger species, frequently attaining $19-20 \mathrm{~mm}$ in length. Posterolateral angles of male widened, slightly projected posteriorly (Figs 2A, 3). Central highlands of Chiapas (Fig. 15)

P. chiapanecus sp. nov.

- Smaller species, never attaining $19 \mathrm{~mm}$ in length. Posterolateral angles of male sharply acute, strongly projected posteriorly (Figs 2D, 6). Inner slope of the Sierra Madre de Chiapas, south-central Guatemala and southeastern Chiapas (Fig. 15).

P. jackenioi sp. nov.

14. Pronotal disc of male completely bright metallic (Figs 2J, 12)

- Pronotal disc of male distinctly black, without metallic reflection (Figs 2E, J, L, 5A, C, 8A, 10A)..

15. Pronotal disc typically bright metallic green, rarely dark metallic blue. Pronotal process of female with central tubercle more developed and anteriorly projected than lateral tubercles. Ecuador (Figs 17, 18A).

P. arletteae Arnaud, 2002

- Pronotal disc typically bright metallic red, green, or dark metallic blue (Figs 2J, 12). Pronotal process of female with tubercles almost aligned, central tubercle not projecting anteriorly (Figs 12C, 18O). Nicaragua and north Caribbean Costa Rica (Fig. 16)....

P. pyrois Bates, 1887

16 Pronotum distinctly bright metallic red frontolaterally. Head bright metallic red with green-yellow metallic sheen (Figs 2F, H, 8, 10) ....

- Pronotum distinctly dull metallic red frontolaterally. Head dull metallic red without green-yellow metallic sheen (Figs 2C, 5). Pacific slope of the Andes, north-central Ecuador and Colombia (Fig. 17) .

P. funereus Balthasar, 1939 stat. rev.

17. Larger species, frequently attaining from 22 to $24 \mathrm{~mm}$ in length. Carinate, distinctly developed keel on central anterior margin of pronotum of male (Fig. 2F). Pronotal posterolateral angles of male strongly developed, projected laterally (Fig. 8A). Pacific slope of the Andes, south-central Colombia and northern Ecuador (Fig. 17)...

.P. olsoufieffi Balthasar, 1939 stat. rev.

- Smaller species, rarely attaining $20 \mathrm{~mm}$ in length. Always with keel absent on central anterior margin of pronotum of male (Fig. 2H). Pronotal posterolateral angles of male weakly developed, widened, and slightly projected posteriorly (Fig. 10A). Caribbean Costa Rica and Panama (Fig. 16) . 


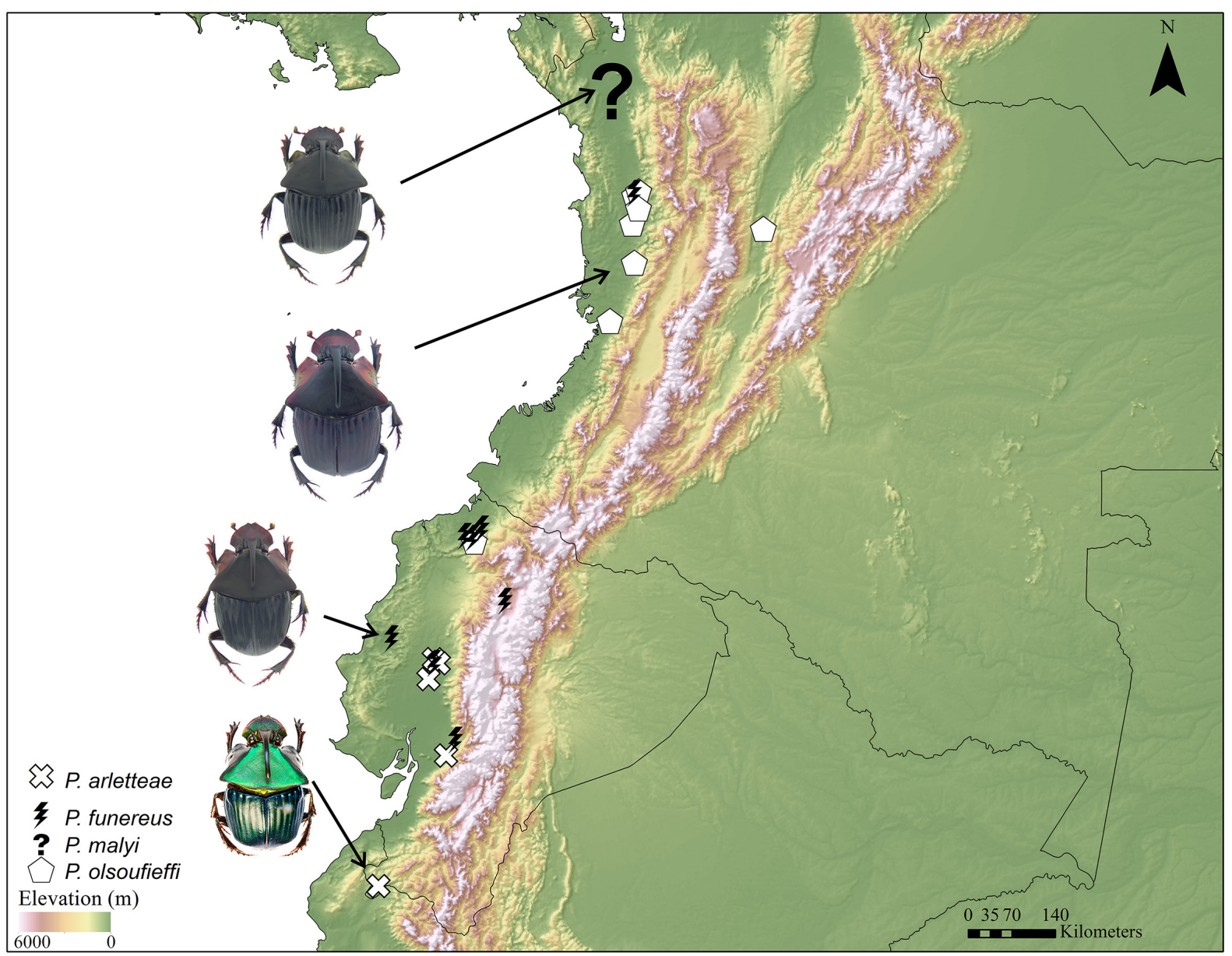

Fig. 17. Distribution of the Phanaeus endymion species group in South America. Phanaeus malyi Arnaud, 2001 was reported from Colombia without accurate locality. Phanaeus arletteae Arnaud, 2018 was modified from Arnaud (2018).

\section{Discussion}

By comparing the external and genital morphology of hundreds of specimens, revisiting the original species descriptions, and examining type material of problematic species (e.g., P. endymion, P. dionysius, P. funereus, $P$. olsoufieffi, $P$. porioni, P. pyrois, $P$. zapotecus), the taxonomy of the $P$. endymion species group has been reassessed and several taxonomical issues were disentangled. As a consequence, five new species have been described and three previously described species have been resurrected from synonymy. Contrary to previous authors (Edmonds 1994; Edmonds \& Zídek 2012; Moctezuma \& Halffter 2017; Moctezuma et al. 2017, 2019), who considered that the morphology of the females within the $P$. endymion species group was relatively homogeneous and taxonomically uninformative, we highlight the importance of the pronotal and cephalic morphology of females to confidently separate closely related species. Furthermore, the morphological variation of females was pivotal in developing a new determination key.

Additionally, we found that in the P. endymion species group body colouration and the morphology of the endophallite copulatrix, which have traditionally been neglected in the taxonomy of Phanaeus (Martínez \& Pereira 1967; Edmonds 1994; Edmonds \& Zídek 2012), can be informative characters. Differences in body colour were accompanied by differences in the external and genital morphology. 


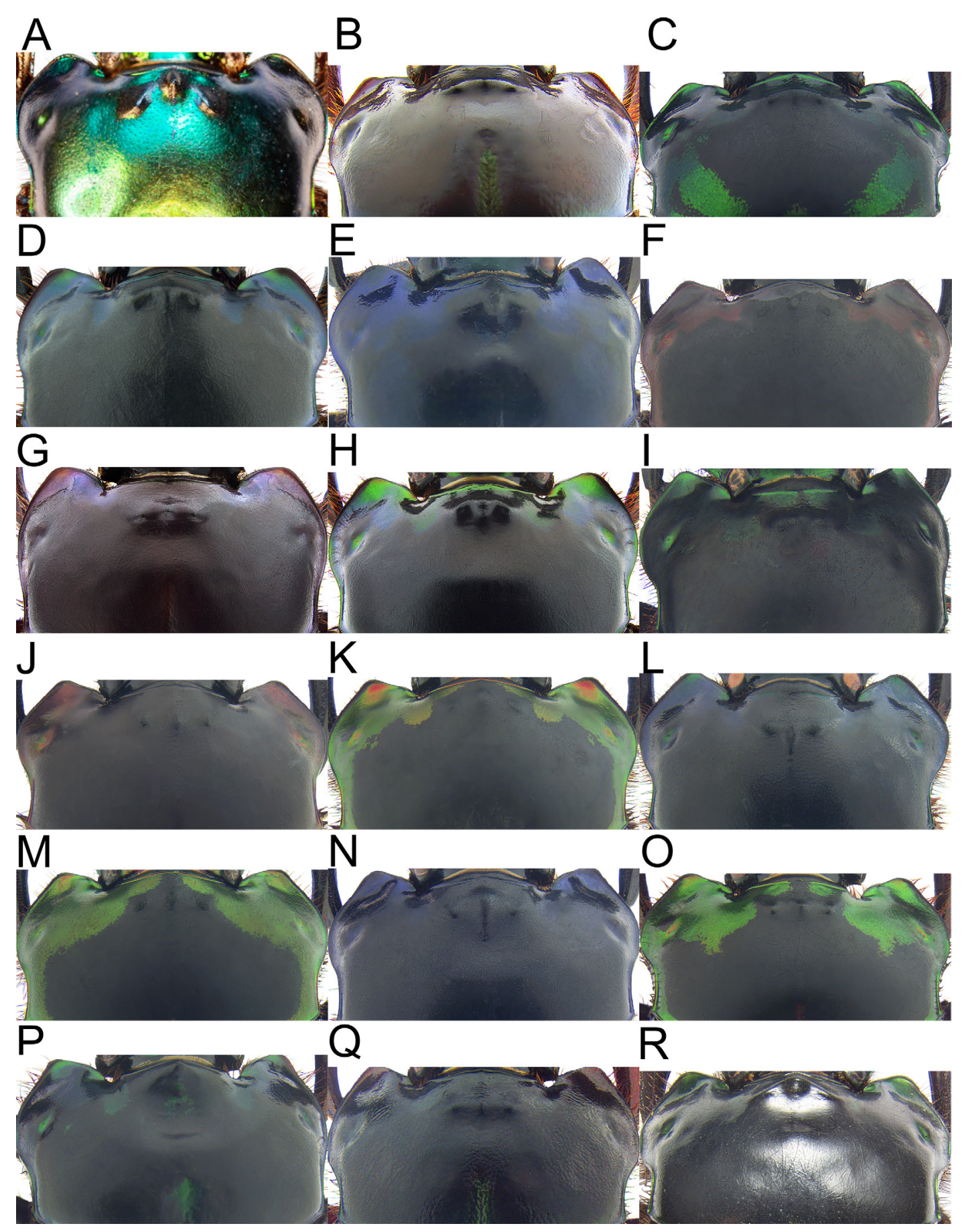

Fig. 18. Pronotum of females within the Phanaeus endymion species group. A. Phanaeus arletteae Arnaud, 2018 (modified from Arnaud 2018). B. Phanaeus bravoensis Moctezuma, Sánchez-Huerta \& Halffter, 2017 (by Jose Luis Sánchez-Huerta). C. Phanaeus chiapanecus sp. nov. D. Phanaeus edmondsi Moctezuma, Deloya \& Halffter, 2019 (by Jose Luis Sánchez-Huerta). E. Phanaeus endymion Harold, 1863. F. Phanaeus funereus Balthasar, 1939 stat. rev. G. Phanaeus halffterorum Edmonds, 1979 (by Jose Luis Sánchez-Huerta). H. Phanaeus huichol Moctezuma, Sánchez-Huerta \& Halffter, 2017 (by Jose Luis Sánchez-Huerta). I. Phanaeus jackenioi sp. nov. J. Phanaeus malyi Arnaud, 2002. K. Phanaeus olsoufieffi Balthasar, 1939 stat. rev. L. Phanaeus pacificus sp. nov. M. Phanaeus panamensis sp. nov. N. Phanaeus porioni Arnaud, 2001 stat. rev. O. Phanaeus pyrois Bates, 1887. P. Phanaeus rzedowskii sp. nov. Q. Phanaeus zapotecus Edmonds, 2006. R. Phanaeus zoque Moctezuma \& Halffter, 2017. 

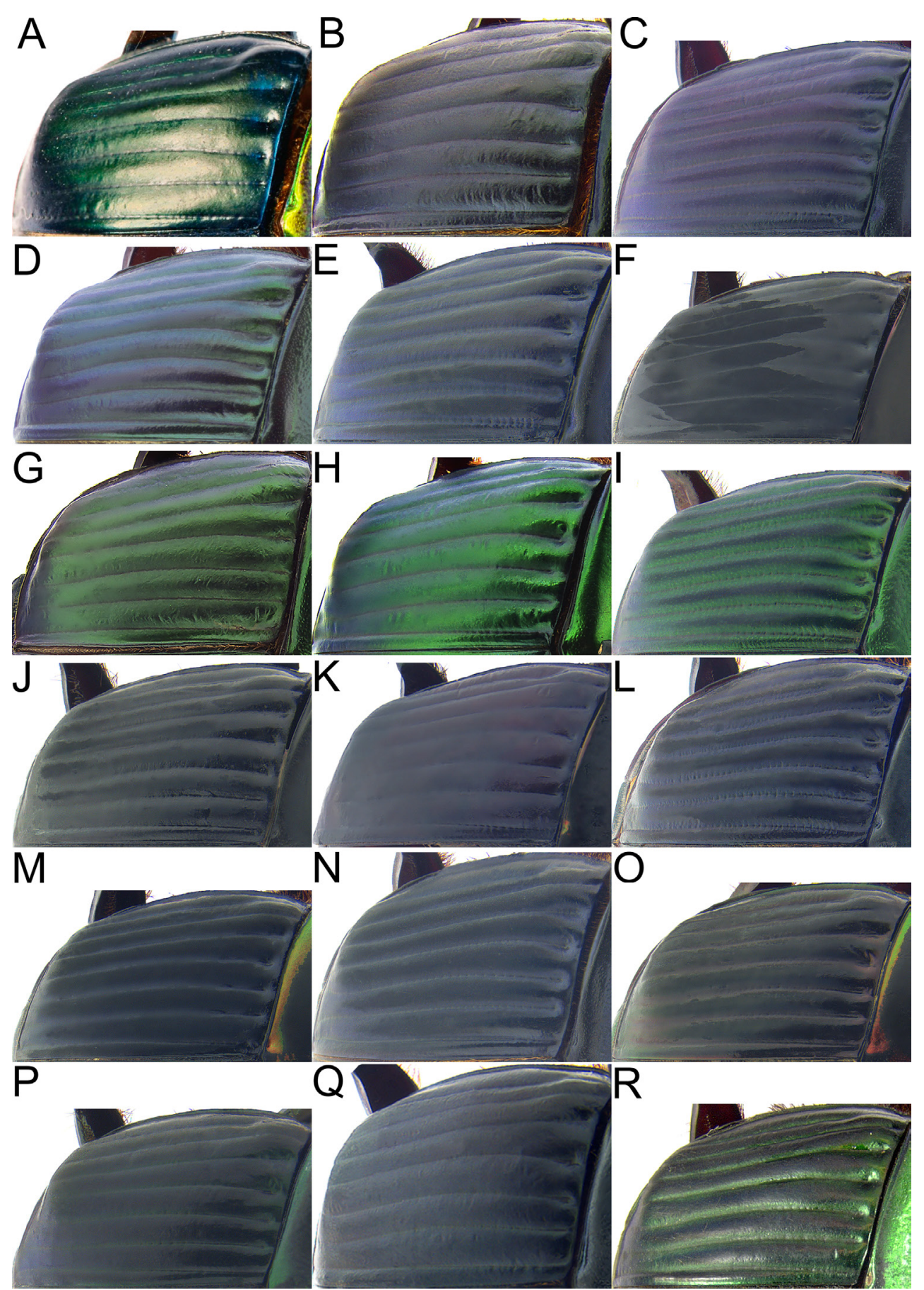

Fig. 19. Elytral integument of species within the Phanaeus endymion species group. A. Phanaeus arletteae Arnaud, 2018 (modified from Arnaud 2018). B. Phanaeus bravoensis Moctezuma, SánchezHuerta \& Halffter, 2017 (by Jose Luis Sánchez-Huerta). C. Phanaeus chiapanecus sp. nov. D. Phanaeus edmondsi Moctezuma, Deloya \& Halffter, 2019 (by Jose Luis Sánchez-Huerta). E. Phanaeus endymion Harold, 1863. F. Phanaeus funereus Balthasar, 1939 stat. rev. G. Phanaeus halffterorum Edmonds, 1979 (by Jose Luis Sánchez-Huerta). H. Phanaeus huichol Moctezuma, Sánchez-Huerta \& Halffter, 2017 (by Jose Luis Sánchez-Huerta). I. Phanaeus jackenioi sp. nov. J. Phanaeus malyi Arnaud, 2002. K. Phanaeus olsoufieffi Balthasar, 1939 stat. rev. L. Phanaeus pacificus sp. nov. M. Phanaeus panamensis sp. nov. N. Phanaeus porioni Arnaud, 2001 stat. rev. O. Phanaeus pyrois Bates, 1887. P. Phanaeus rzedowskii sp. nov. Q. Phanaeus zapotecus Edmonds, 2006. R. Phanaeus zoque Moctezuma \& Halffter, 2017. 
Prior studies have demonstrated that at least in some instances, differences in body colouration may be supported by molecular sequence data as demonstrated by Solís \& Kohlmann (2012). Since Phanaeus are diurnal beetles, body colour and iridescence are expected to be important for mate choice and visual social signaling directed to conspecifics and predators (Vulinec 1997), while both body colour and iridescence are a result of light absorption and the interference in reflected light rays propagating through micron-sized structures composed of organized nano-sized elements of the beetle cuticles (Michelson 1911; Vargas et al. 2018).

Therefore, we conclude that earlier authors underestimated the usefulness of body colouration to diagnose closely related species within the P. endymion species group (Martínez \& Pereira 1967; Edmonds 1994; Edmonds \& Zídek 2012), and the microstructures responsible of body colour and iridescence in Phanaeus cuticles might be a new and unexplored source of taxonomic characters. Additionally, the morphology of the endophallite copulatrix was reported to be homogeneous in closely related species of the $P$. amethystinus, $P$. quadridens, $P$. tridens and $P$. vindex species groups (Price 2005; Moctezuma et al. 2020). However, this is not the case with the $P$. endymion species group, for which we found a significant interspecific variation in the morphology of the endophallite copulatrix (Fig. 1). The wide genital variety of males might be a driver of diversification within the $P$. endymion species group, since variation in genital structures is thought to drive a rapid evolutionary divergence in other groups of arthropods (Yao et al. 2020). Nevertheless, further corroboration of our taxonomic conclusions using independent data such as DNA sequences for all relevant taxa would be desirable.

In addition, we consider that the most complete taxonomic treatment for the genus Phanaeus was proposed by Arnaud (2002b), as previously suggested by Moctezuma et al. (2020) for the P. quadridens species group. Nevertheless, Arnaud's (2002b) classification has limitations, such as the use of the subspecieslevel without clear boundaries between species and subspecies. Future revisions of Phanaeus are needed because the species richness of this genus might be dramatically underestimated since Arnaud (2002b) proposed 77 taxa (species and subspecies) and 34 synonyms, while Edmonds \& Zídek (2012) recognized only 54 valid species and suggested 53 synonyms.

As recognized herein, the $P$. endymion species group is the most species-rich grouping of rainbow scarab dung beetles within Phanaeus, encompassing 18 species. Other diverse species groups are those of $P$. mexicanus (11 taxa), P. tridens (10 taxa) and P. chalcomelas (9 taxa). On the other hand, the P. amethystinus (6 taxa), P. hermes (5 taxa), P. palaeno (5 taxa), P. quadridens (5 taxa), P. splendidulus (5 taxa), $P$. beltianus (4 taxa), P. triangularis (4 taxa) and $P$. vindex (4 taxa) species groups show a

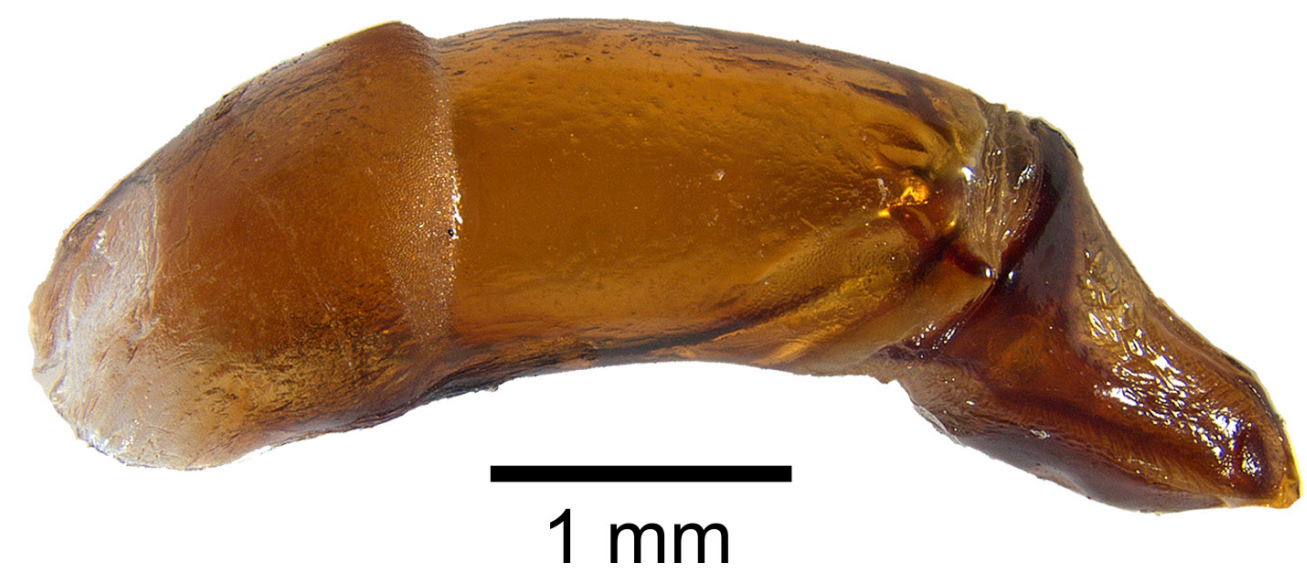

Fig. 20. Lateral view of the aedeagus of the Phanaeus endymion species group (P. endymion Harold, 1863). 
discrete diversity; while the P. bispinus species group (2 taxa) is the most species-poor (Arnaud 2002b; Edmonds 2006; Moctezuma et al. 2020). Consequently, the genus Phanaeus might incorporate at least 87 taxa, a number that undoubtedly will increase with the discovery of additional undescribed species in future revisions.

A former classification (Edmonds 1994; Edmonds \& Zídek 2012) presented the P. endymion species group as a species-poor lineage, with two widely distributed species in the tropical forests (P. endymion and $P$. pyrois) and two endemics to mountain temperate forests ( $P$. halffterorum and P. zapotecus). Consequently, we proposed that the $P$. endymion species group represented a recent penetration of Neotropical origin that arrived in Mexico during the Plio-Pleistocene climatic fluctuations (Halffter \& Morrone 2017; Moctezuma \& Halffter 2017). In this context, P. endymion and P. pyrois were considered as putatively basal taxa, while $P$. halffterorum, $P$. zapotecus and $P$. zoque represented marginal colonizations of montane regions (Moctezuma \& Halffter 2017).

Nevertheless, some considerations arose as follows. The term "basal taxa" does not make sense, because every branching in a phylogenetic tree is rotatable. Consequently, there are always two most basal clades, both originating from a node with equal age and evolutionary change (Krell \& Cranston 2004). Additionally, the $P$. endymion species group is widely distributed in montane regions. The $P$. endymion species group contains several species associated with tropical rainforests (P. arletteae, P. edmondsi, P. endymion, P. funereus, P. malyi, P. olsoufieffi, P. pacificus sp. nov., P. panamensis sp. nov., P. porioni, P. pyrois), mountain cloud forests (P. endymion) and tropical dry forests (P. arletteae, P. bravoensis, $P$. chiapanecus sp. nov.). On the other hand, at least seven species inhabit the temperate coniferous-oak forests of Mesoamerica (P. bravoensis, $P$. halffterorum, P. huichol, P. jackenioi sp. nov., P. rzedowskii sp. nov., P. zapotecus and $P$. zoque). Apparently, the diversification of the $P$. endymion species group and its dispersal to the Mexican temperate forests started during the Miocene (Price 2009; Kohlmann et al. 2018; Gillett \& Toussaint 2020).

We hypothesize that the $P$. endymion species group has a significant plasticity to invade new ecological niches. The ecological plasticity of the $P$. endymion species group is supported by the heterogeneous ecosystems that it inhabits, such as the aforementioned tropical rainforests, tropical dry forests, mountain cloud forests, and temperate coniferous-oak forests (Edmonds 1994, 2003, 2006; Moctezuma \& Halffter 2017; Moctezuma et al. 2017, 2019). Furthermore, some species may be opportunistic to invade forest borders and tropical pastures, such as P. endymion (Edmonds 1994, 2003; Salomão et al. 2020). The invasion of the $P$. endymion species group to these environments (such as the temperate forests and tropical pastures) might involve the development of adaptations in ecophysiological processes (e.g., respiration and temperature control) to tolerate dryness and microclimatic changes (Chown \& Klok 2011; Moctezuma et al. 2016).

On the other hand, the P. endymion species group is the only one within Phanaeus that successfully shifted from coprophagy to necrophagy, mycetophagy and saprophagy (Halffter \& Matthews 1966; Edmonds 1994, 2003, 2006; Halffter \& Halffter 2009; Deloya et al. 2013; Gillett \& Toussaint 2020). A combination of both the evolution of mandible morphology and symbiotic interactions may explain the remarkable trophic generalism of the $P$. endymion species group. The modifications of mandible morphology are known to be a key factor that allowed the evolution from the saprophagous ancestors to the modern coprophagous Scarabaeinae (Bai et al. 2015), while the effects of digestive symbionts have driven trophic generalism in herbivorous beetles (McKenna et al. 2019; Salem et al. 2020) and are responsible of facilitating digestion and nutrition process in dung beetles (Thiyonila et al. 2018; SuárezMoo et al. 2020). 
Although our study adhered to the phylogenetic species concept sensu Wheeler \& Platnick (2000), we hope that the species described and redescribed herein are compatible with other popular species concepts, such as the biological species concept sensu Mayr (1942). The biological species concept emphasizes that reproductive isolation is the key characteristic between independent species (Zachos 2016; Nosil et al. 2017; Cupello \& Vaz-de-Mello 2018; Huang 2020). Each species defined herein shows a unique morphology of the endophallite copulatrix. Therefore, sexual isolation between species of the P. endymion species group is expected, since differences in the morphology of the endophallites in Scarabaeinae dung beetles are considered as prezygotic mechanical barriers that may prevent interbreeding (Price 2005; Werner \& Simmons 2008; Moretto \& Génier 2020). The morphology of the endophallites has exhibited high levels of interspecific variation in other groups of Scarabaeinae dung beetles (Howden \& Gill 1993; Joaqui et al. 2019; Moctezuma \& Halffter 2020; Moretto \& Génier 2020), while this variation is expected to have a strong phylogenetic signal to discriminate different evolutionary lineages (Tarasov \& Solodovnikov 2011; Tarasov \& Génier 2015).

\section{Acknowledgments}

We thank the Dirección General of the Instituto de Ecología, A.C. (no. 20035/30916), the Fondo Sectorial de Investigación para la Educación SEP-CONACyT Mexico (no. 257039), and the Organization for Tropical Studies (Hovore-Horn Fellowship no. 3116) for funding this work. The first author received a grant for graduate studies (no. 412700) and research assistant activities (exp. no. 18627) by CONACyT Mexico. The authors greatly appreciate the kindness of Mario Cupello (P. pyrois), Patrick Arnaud (P. porioni), José Luis Sánchez-Huerta ( $P$. bravoensis, $P$. edmondsi, $P$. halffterorum and $P$. huichol), the Národní Muzeum (particular thanks to Jiří Hájek: $P$. funereus), and the Muséum national d'histoire naturelle (particular thanks to Christophe Rivier: P. endymion and $P$. olsoufieffi) for providing images of type specimens. We acknowledge the generosity of the Texas A\&M University Insect Collection (especially to Edward Riley and Karen Wright) and the Colección Entomológica de la Universidad del Valle de Guatemala (particular thanks to Jack Schuster and Enio Cano) for the loan and exchange of several interesting specimens of Phanaeus. David Edmonds was instrumental to study his former personal collection, currently deposited at the Texas A\&M University Insect Collection. We appreciate the opportunity for studying the different entomological collections to Cuauhtémoc Deloya (Instituto de Ecología, A.C.), Delfino Hernandéz (Colección Entomológica Dr. Miguel Angel Morón Ríos, Instituto de Ecología, A.C.), Federico Escobar (Instituto de Ecología, A.C.) and Fernando Z. Vaz-deMello (Seção de Entomologia da Coleção Zoológica da Universidade Federal de Mato Grosso). Patrick Arnaud kindly gifted a pair of paratypes of $P$. porioni and relevant literature to the first author. The first author thanks Antoine Mantilleri (Muséum national d'histoire naturelle) for an important discussion on the type series of $P$. olsoufieffi. Guillermo Nogueira is acknowledged for his contribution to collect some interesting specimens of $P$. huichol. Jen-Pan Huang (Biodiversity Research Center, Academia Sinica, Taipei, Taiwan) kindly revised a preliminary version of the manuscript and provided valuable comments and corrections. Two anonymous reviewers helped to improve this work.

\section{References}

Agassiz J.L.R. 1846. Nomenclatoris zoologici index universalis, continens nomina systematica classium, ordinum, familiarum et generum animalium omnium, tam viventium quam fossilum, secundum ordinem alphabeticum unicum deposita, adjectis homonymus platarum, nec non variis adnotationibus et emendationibus. Jent \& Gassman, Soloduri.

Alvarado F., Escobar F. \& Montero-Muñoz J. 2014. Diversity and biogeographical makeup of the dung beetle communities inhabiting two mountains in the Mexican Transition Zone. Organisms Diversity \& Evolution 14: 105-114. https://doi.org/10.1007/s13127-013-0148-0 
Alvarado F., Dátillo W. \& Escobar F. 2019. Linking dung beetle diversity and its ecological function in a gradient of livestock intensification management in the Neotropical region. Applied Soil Ecology 143: 173-180. https://doi.org/10.1016/j.apsoil.2019.06.016

Alvarado F., Salomão R.P., Hernández-Rivera A. \& Lira A.F.d.A. 2020. Different responses of dung beetle diversity and feeding guilds from natural and disturbed habitats across a subtropical elevational gradient. Acta Oecologica 104: 103533. https://doi.org/10.1016/j.actao.2020.103533

Anduaga S. 2000. Escarabajos coprófagos (Coleoptera: Scarabaeoidea) asociados a hongos en la Sierra Madre Occidental, Durango, México: con una compilación de las especies micetófagas. Acta Zoológica Mexicana (n.s.) 80: 119-130.

Anduaga S. \& Halffter G. 1991. Micofagia en Scarabaeidae. In: Navarrete-Heredia J.L. \& QuirozRocha G.A. (eds) Memorias del I Simposio Nacional sobre la Interacción Insecto-Hongo: 151-169. S.M.E. Facultad de Ciencias, IGU, Veracruz.

Arellano L., León-Cortés J.L. \& Halffter G. 2008. Response of dung beetle assemblages to landscape structure in remnant natural and modified habitats in southern Mexico. Insect Conservation \& Diversity 1: 253-262. https://doi.org/10.1111/j.1752-4598.2008.00033.x

Arellano L., León-Cortés J.L., Halffter G. \& Montero J. 2013. Acacia woodlots, cattle and dung beetles (Coleoptera: Scarabaeinae) in a Mexican silvopastoral landscape. Revista Mexicana de Biodiversidad 84: 650-660. https://doi.org/10.7550/rmb.32911

Arnaud P. 1982. Liste des types de Phanaeini du Muséum National D'Histoire Naturelle de Paris [Coleoptera, Scarabaeidae]. Revue française d'Entomologie (N.S.) 4: 113-118.

Arnaud P. 2000. Description de nouvelles espèces de Phanaeides. (Col. Scarabaeidae). Besoiro 5: 6-8.

Arnaud P. 2001. Description de nouvelles espèces de Phanaeides. (Col. Scarabaeidae). Besoiro 6: 2-8.

Arnaud P. 2002a. Description de nouvelles espèces de Phanaeides. (Col. Scarabaeidae). Besoiro 8: 2-5.

Arnaud P. 2002b. Phanaeini. Dendropaemon, Tetramereia, Homalotarsus, Megatharsis, Diabroctis, Coprophanaeus, Oxysternon, Phanaeus, Sulcophanaeus. Hillside Books, Canterbury.

Arnaud P. 2018. Description d'une nouvelle espèce de Phanaeus d'Équateur et revalidation de l'espèce Coprophanaeus (C.) edmondsi Arnaud (Coleoptera : Scarabaeidae, Scarabaeinae). Besoiro 26: 3-7.

Avendaño-Mendoza C., Morón-Ríos A., Cano E.B. \& León-Cortés J. 2005. Dung beetle community (Coleoptera: Scarabaeidae: Scarabaeinae) in a tropical landscape at the Lachua Region, Guatemala. Biodiversity \& Conservation 14: 801-822. https://doi.org/10.1007/s10531-004-0651-x

Bai M., Li S., Lu Y., Yang H., Tong Y. \& Yang X. 2015. Mandible evolution in the Scarabaeinae (Coleoptera: Scarabaeidae) and adaptations to coprophagous habits. Frontiers in Zoology 12: 30.

https://doi.org/10.1186/s12983-015-0123-z

Balthasar V. 1939. Neue Phanaeus - Arten. Folia Zoologica et Hydrobiologica 9: 238-247.

Barragán F., Moreno C.E., Escobar F., Halffter G. \& Navarrete D. 2011. Negative impacts of human land use on dung beetle functional diversity. PLoS One 6: e17976.

https://doi.org/10.1371/journal.pone.0017976

Bates H.W. 1887. Biologia Centrali-Americana. Insecta. Coleoptera. Vol. II. Part 2. Pectinicornia and Lamellicornia. Taylor \& Francis, London.

Available from https://www.biodiversitylibrary.org/item/135502\#page/7/mode/1up [accessed Jun. 2020]. 
Blackwelder R.E. 1944-1957. Checklist of the coleopterous insects of Mexico, Central American, the West Indies, and South America. Parts 1-6. United States National Museum, Bulletin 185: 1-1492. https://doi.org/10.5479/si.03629236.185.927

Bourg A., Escobar F., MacGregor-Fors I. \& Moreno C.C. 2016. Got dung? Resource selection by dung beetles in Neotropical forest fragments and cattle pastures. Neotropical Entomology 45: 490-498. https://doi.org/10.1007/s13744-016-0397-7

Brullé A. 1837. Histoire naturelle des insectes, comprenant leur classification, leurs mœurs et la description des espèces. In: Audouin M.V. \& Brullé A. (eds) Histoire naturelle des Insectes, comprenant leur Classification, leurs Moeurs, et la Description des Espèces. Tome VI, Coléoptères III. F.D. Pillot, Paris.

Cancino-López R.J., Chamé-Vázquez E.R. \& Gómez y Gómez B. 2014. Escarabajos necrófilos (Coleoptera: Scarabaeinae) en tres hábitats del Volcán Tacaná, Chiapas, México. Dugesiana 21: 135142.

Capello V. \& Halffter G. 2019. Listado ilustrado de las especies de Scarabaeinae (Coleoptera: Scarabaeidae) de la Reserva de la Biósfera de Calakmul, Campeche, México. Dugesiana 26: 103-131.

Castelnau M. 1840. Histoire naturelle des coléoptères. Histoire naturelle des Animaux articulés, Annélides, Crustacés, Arachnides, Myriapodes et Insectes. Vol. 2. P. Duménil, Paris.

Ceballos G., List R., Garduño G., López-Cano R., Muñozcano-Quintanar M.J., Collado E. \& San-Román J.E. 2009. La diversidad biológica del Estado de México. Estudio de estado. Gobierno del Estado de México, Toluca de Lerdo.

Chamorro W., Marín-Armijos D., Granda V. \& Vaz-de-Mello F.Z. 2018. Listado de especies y clave de géneros y subgéneros de escarabajos estercoleros (Coleoptera: Scarabaeidae: Scarabaeinae) presentes y presuntos para Ecuador. Revista Colombiana de Entomología 44: 72-100.

https://doi.org/10.25100/socolen.v44i1.6545

Chamorro W., Marin-Armijos D. \& Asenjo A. 2019. Scarabaeinae dung beetles from Ecuador: a catalog, nomenclatural acts, and distribution records. ZooKeys 826: 1-343.

https://doi.org/10.3897/zookeys.826.26488

Chown S.L. \& Klok C.J. 2011. The ecological implications of physiological diversity in dung beetles. In: Simmons L.W. \& Ridsdill-Smith T.J. (eds) Ecology and Evolution of Dung Beetles: 200-219. Blackwell Publishing Ltd, West Sussex. https://doi.org/10.1002/9781444342000.ch10

Creedy T.J. \& Mann D.J. 2011. Identification Guide to the Scarabaeinae Dung Beetles of Cusuco National Park, Honduras. Version 1.0. Operation Wallacea, Lincolnshire.

Cristóvão J.P. \& Vaz-de-Mello F.Z. 2020. The terminalia of the superfamily Scarabaeoidea (Coleoptera): specific glossary, dissecting methodology, techniques and previously unrecorded sexual dimorphism in some difficult groups. Zoological Journal of the Linnean Society: zlaa079.

https://doi.org/10.1093/zoolinnean/zlaa079

Cupello M. \& Vaz-de-Mello F.Z. 2018. A monographic revision of the Neotropical dung beetle genus Sylvicanthon Halffter \& Martínez, 1977 (Coleoptera: Scarabaeidae: Scarabaeinae: Deltochilini), including a reappraisal of the taxonomic history of 'Canthon sensu lato'. European Journal of Taxonomy 467: 1-205. https://doi.org/10.5852/ejt.2018.467

Dawson R.W. 1922. A synopsis of the Scarabaeidae of Nebraska. University Studies of the University of Nebraska 22: 163-244. 
Dejean P.F. 1844. Catalogue des Coléoptères de la Collection de M. Le Comte Dejean. Troisième édition, revue, corrigée et augmentée. Chez Méquignon-Maris père et fils, Paris.

https://doi.org/10.5962/bhl.title.8771

Delgado-Castillo L., Navarrete-Heredia J.L. \& Blackaller-Bages J. 1993. A new Mexican species of Onthophagus with mycophagous habits (Coleoptera: Scarabaeidae: Scarabaeinae). The Coleopterists Bulletin 47: 121-126. Available from https://www.jstor.org/stable/4008857 [accessed 2 Mar. 2021].

Delgado L., Mora-Aguilar E.F. \& Escobar-Hernández F. 2012a. Scarabaeoidea (Coleoptera) of the municipality of Xalapa, Veracruz, Mexico: inventory and analysis. The Coleopterists Bulletin 66: 319332. https://doi.org/10.1649/072.066.0405

Delgado J.M., Castro-Ramírez A.E., Morón M.A. \& Ruíz-Montoya L. 2012b. Different responses of dung beetle diversity and feeding guilds from natural and disturbed habitats across a subtropical elevational gradient. Acta Zoológica Mexicana (n. s.) 28: 185-210.

Deloya C. \& Morón M.A. 1998. Scarabaeoidea (Insecta: Coleoptera) necrófagos de "Los Tuxtlas", Veracruz y Puerto Ángel, Oaxaca, México. Dugesiana 5: 17-28.

Deloya C., Burgos A., Blackaller J. \& Lobo J.M. 1993. Los coleópteros lamelicornios de Cuernavaca, Morelos, México (Passalidae, Trogidae, Scarabaeidae y Melolonthidae). Boletín de la Sociedad veracruzana de Zoología 3: 15-55.

Deloya C., Madora-A M. \& Covarrubias-M D. 2013. Scarabaeidae y Trogidae (Coleoptera) necrófilos de Acahuizotla, Guerrero, México. Revista Colombiana de Entomología 39: 88-94.

Deloya C., Calvo-Gática H., García-Díaz O.J., Rendón-Sosa M., González-Hilario S. \& AguirreLeón G. 2014. Capítulo 10. Familia Scarabaeidae Latreille, 1802. In: Deloya C., Covarrubias-Melgar D. (eds) Escarabajos del estado de Guerrero (Coleoptera: Scarabaeoidea): 69-116. S y G Editores, Mexico City.

Díaz A., Galante E. \& Favila M.E. 2010. The effect of the landscape matrix on the distribution of dung and carrion beetles in a fragmented tropical rain forest. Journal of Insect Science 10: 81.

https://doi.org/10.1673/031.010.8101

Edmonds W.D. 1972. Comparative skeletal morphology, systematics and evolution of the Phanaeine dung beetles (Coleoptera: Scarabaeidae). The University of Kansas Science Bulletin 49: 731-874.

Edmonds W.D. 1979. A new species of Phanaeus from Mexico (Coleoptera: Scarabaeidae). Pan-Pacific Entomologist 55: 99-105.

Edmonds W.D. 1994. Revision of Phanaeus Macleay, a New World genus of Scarabaeinae dung beetles (Coleoptera: Scarabaeidae, Scarabaeinae). Contributions in Science, Natural History Museum of Los Angeles County 443: 1-105.

Available from http://journals.flvc.org/mundi/article/view/81568/78697 [accessed Jul. 2020].

Edmonds W.D. 2003. Tribu Phanaeini. In: Morón M.A. (ed.) Atlas de los escarabajos de México. Coleoptera: Lamellicornia. Vol. II. Familias Scarabaeidae, Trogidae, Passalidae y Lucanidae: 58-65. Argania Editio, Barcelona.

Edmonds WD. 2004. A new species of Phanaeus Macleay (Coleoptera: Scarabaeidae, Scarabaeinae) from Sonora, Mexico. The Coleopterists Bulletin 58: 119-124. https://doi.org/10.1649/697

Edmonds W.D. 2006. A new species of Phanaeus Macleay (Coleoptera: Scarabaeidae: Scarabaeinae: Phanaeini) from Oaxaca, Mexico. Zootaxa 1171 (3): 31-37. https://doi.org/10.11646/zootaxa.1171.1.3 
Edmonds W.D. \& Halffter G. 1978. Taxonomic review of immature dung beetles of the dung beetles of the subfamily Scarabaeinae (Coleoptera: Scarabaeidae). Systematic Entomology 3: 307-331.

https://doi.org/10.1111/j.1365-3113.1978.tb00002.x

Edmonds W.D. \& Zídek J. 2012. Taxonomy of Phanaeus revisited: Revised keys to and comments on species of the New World dung beetle genus Phanaeus Macleay, 1819 (Coleoptera: Scarabaeidae: Scarabaeinae: Phanaeini). Insecta Mundi 274: 1-108.

Available from https://digitalcommons.unl.edu/insectamundi/784/ [accessed Jul. 2020].

Estrada A. \& Coates-Estrada R. 1991. Howler monkeys (Alouatta palliata), dung beetles (Scarabaeidae) and seed dispersal: Ecological interactions in the tropical rain forest of Los Tuxtlas, Mexico. Journal of Tropical Ecology 7: 459-474. https://doi.org/10.1017/S026646740000585X

Estrada A., Halffter G., Coates-Estrada R. \& Meritt D.A. Jr. 1993. Dung beetles attracted to mammalian herbivore (Alouatta palliata) and omnivore (Nasua narica) dung in the tropical rain forest of Los Tuxtlas, Mexico. Journal of Tropical Ecology 9: 45-54. https://doi.org/10.1017/S0266467400006933

Estrada A., Coates-Estrada R., Anzures-Dadda A. \& Cammarano P. 1998. Dung and carrion beetles in tropical rain forest fragments and agricultural habitats at Los Tuxtlas, Mexico. Journal of Tropical Ecology 14: 577-593. https://doi.org/10.1017/S0266467498000418

Figueroa L., Edmonds W.D. \& Martínez N.L. 2014. La tribu Phanaeini (Coleoptera, Scarabaeidae, Scarabaeinae) en el Perú. Revista peruana de Biología 21: 125-138.

https://doi.org/10.15381/rpb.v21i2.9815

GBIF Secretariat. 2019a. Phanaeus endymion Harold, 1863. GBIF Backbone Taxonomy. Checklist dataset. Available from https://doi.org/10.15468/39omei [accessed Jul. 2020].

GBIF Secretariat. 2019b. Phanaeus pyrois Bates, 1887. GBIF Backbone Taxonomy. Checklist dataset. Available from https://doi.org/10.15468/39omei [accessed Jul. 2020].

Gemminger M. \& Harold E. 1869. Catalogous Coleopterorum hucusque descriptorum synonymicus et systematicus. Monachii, Sumptu EH Gummi 4: 979-1346. https://doi.org/10.5962/bhl.title.9089

Génier F. 2019. Endophallites: a proposed neologism for naming the sclerotized elements of the insect endophallus (Arthropoda: Insecta). Annales de la Société entomologique de France (N.S.) 55: 482-484. https://doi.org/10.1080/00379271.2019.1685907

Germar E.F. 1824. Insectorum species novae aut minus cognotae, descriptionibus illustratae. Hendelii et Fillii, Halae. https://doi.org/10.5962/bhl.title.130964

Gillet J.J.E. 1911. Coleopterorum Catalogus. Pars 38: Scarabaeidae: Coprinae. I.W. Junk, Berlin.

Gillett C.P.D.T. 2008. Collecting in Belize May/June 2006. Scarabs 29: 1-14.

Gillett C.P.D.T. \& Toussaint E.F.A. 2020. Macroevolution and shifts in the feeding biology of the New World scarab beetle tribe Phanaeini (Coleoptera: Scarabaeidae: Scarabaeinae). Biological Journal of the Linnean Society 130: 661-682. https://doi.org/10.1093/biolinnean/blaa058

Gillett C.P.D.T., Gillett M.P.T., Gillett J.E.D.T \& Vaz-de-Mello F.Z. 2010. Diversity and distribution of the scarab beetle tribe Phanaeini in the northern states of the Brazilian Northeast (Coleoptera: Scarabaeidae: Scarabaeinae). Insecta Mundi 118: 1-19.

Gistel J.N.F.X. 1857. Achthundert und zwanzig neue oder unbeschriebene wirbellose Thiere. Schorner, Straubing.

Halffter G. 1952. Notas sobre el género Phanaeus. I. Phanaeus quadridens Say, 1835. Ciencia 11: $79-86$. 
Halffter G. 1955. Notas sobre el género Phanaeus. II. Phanaeus martinezi nov. sp. Ciencia 12: 79-86.

Halffter G. 2017. La zona de transición mexicana y la megadiversidad de México: del marco histórico a la riqueza actual. Dugesiana 24: 77-89.

Halffter G. \& Edmonds W.D. 1982. The nesting Behavior of Dung Beetles (Scarabaeinae). An ecological and evolutive Approach. Instituto de Ecología, Mexico City.

Halffter G. \& Halffter V. 2009. Why and where coprophagous beetles (Coleoptera: Scarabaeinae) eat seeds, fruits of vegetable detritus. Boletín de la Sociedad Entomológica Aragonesa 45: 1-22.

Halffter G. \& Matthews E.G. 1966. The natural history of dung beetles of the subfamily Scarabaeinae (Coleoptera: Scarabaeidae). Folia Entomológica Mexicana 12-14: 1-312.

Halffter G. \& Morrone J.J. 2017. An analytical review of Halffter's Mexican transition zone, and its relevance for evolutionary biogeography, ecology and biogeographical regionalization. Zootaxa 4226: 1-46. https://doi.org/10.11646/zootaxa.4226.1.1

Halffter G., Favila M.E. \& Halffter V. 1992. A comparative study of the structure of the scarab guild in Mexican tropical rain forests and derived ecosystems. Folia Entomológica mexicana 84: 131-156.

Halffter G., Favila M.E. \& Arellano L. 1995. Spatial distribution of three groups of Coleoptera along and altitudinal transect in the Mexican Transition Zone and its biogeographical implications. Elytron 9: $151-185$.

Hamel-Leigue A., Mann D.J., Vaz-de-Mello F.Z. \& Herzog S.K. 2006. Hacia un inventario de los escarabajos peloteros (Coleoptera: Scarabaeinae) de Bolivia: primera compilación de los géneros y especies registrados para el país. Revista Boliviana de Ecología y Conservación Ambiental 20: 1-18.

Hamel-Leigue A., Herzog S.K., Mann D.J., Larsen T.H., Gill B.D., Edmonds W.D. \& Spector S. 2009. Distribución e historia natural de escarabajos coprófagos de la tribu Phanaeini (Coleoptera: Scarabaeidae: Scarabaeinae) en Bolívia. Kempffiana 5: 43-95.

Harold E. 1863. Note sur les espèces mexicaines du genre Phanaeus et descriptions de quelques espèces nouvelles de coléoptères mexicains. Annales de la Société entomologique de France 3: 161-176.

Harold E. 1871. Berichtigungen und Zusätze zum Catalogus Coleopterorum synonymicus et systematicus. Coleopterologische Hefte 7: 113-119.

Harris R.A. 1979. A glossary of surface sculpturing. Occasional Papers in Entomology 28: 1-31. https://doi.org/10.5281/zenodo.26215

Hinton H.E. 1935. Anotaciones acerca de las costumbres micetofágicas de las especies de Phanaeus. Anales del Instituto de Biología, UNAM (Serie Zoología) 6: 129-130.

Horgan F.G. 2001. Burial of bovine dung by coprophagous beetles (Coleoptera: Scarabaeidae) from horse and cow grazing sites in El Salvador. European Journal of Soil Biology 37: 103-111. https://doi.org/10.1016/S1164-5563(01)01073-1

Horgan F.G. 2008. Dung beetle assemblages in forests and pastures of El Salvador: a functional comparison. Biodiversity \& Conservation 17: 2961-2978. https://doi.org/10.1007/s10531-008-9408-2

Howden H.F. \& Gill B.D. 1993. Mesoamerican Onthophagus Latreille in the dicranius and mirabilis species groups (Coleoptera: Scarabaeidae). The Canadian Entomologist 125: 1091-1114. https://doi.org/10.4039/Ent1251091-6

Howden H.F. \& Young O.P. 1981. Panamanian Scarabaeinae: Taxonomy, distribution, and habits (Coleoptera, Scarabaeidae). Contributions of the American Entomological Institute 18: 1-204. 
Huang J.P. 2020. Is population subdivision different from speciation? From phylogeography to species delimitation. Ecology \& Evolution 10 (14): 6890-6896. https://doi.org/10.1002/ece3.6524

Huerta C., Arellano L., Cruz M., Escobar F. \& Martínez I. 2016. Los escarabajos del estiércol en los potreros ganaderos de Xico. Instituto de Ecología, A.C., Xalapa.

ICZN. 1999. International Code of Zoological Nomenclature. Fourth Edition. International Commission on Zoological Nomenclature, the International Trust for Zoological Nomenclature, London.

Inward D.J.G., Davies R.G., Pergande C., Denham A.J. \& Vogler A.P. 2011. Local and regional ecological morphology of dung beetle assemblages across four biogeographic regions. Journal of Biogeography 38: 1668-1682. https://doi.org/10.1111/j.1365-2699.2011.02509.x

Islas F. 1942. Las especies mexicanas de los géneros Canthon Hffsg. y Phanaeus Mc'Leay. Col. Scarabaeidae. Anales del Instituto de Biología de la Universidad nacional de México 13: 301-340.

Joaqui T., Moctezuma V., Sánchez-Huerta J.L. \& Escobar F. 2019. The Onthophagus fuscus (Coleoptera: Scarabaeidae) species complex: an update and the description of a new species. Zootaxa 4555 (1): 151186. https://doi.org/10.11646/zootaxa.4555.2.1

Kohlmann B., Arriaga-Jiménez A. \& Rös M. 2018. Dung beetle vicariant speciation in the mountains of Oaxaca, Mexico, with a description of a new species of Phanaeus (Coleoptera, Geotrupidae, Scarabaeidae). ZooKeys 743: 67-93. https://doi.org/10.3897/zookeys.743.23029

Komarek A. \& Beutel R.G. 2006. Problems in taxonomy and suggestions for a standardized description of new insect taxa. Entomological Problems 36: 55-70.

Krajcik M. 2006. Checklist of Scarabaeoidea of the World. 1. Scarabaeinae (Coleoptera: Scarabaeidae: Scarabaeinae). Animma.X. Suplement 3: 1-189.

Krell F.T. \& Cranston P.S. 2004. Which side of the tree is more basal? Systematic Entomology 29: 279-281. https://doi.org/10.1111/j.0307-6970.2004.00262.x

Lacordaire J.T. 1856. Histoire naturelle des insectes. Genera des coléoptères, ou exposé méthodique et critique de tous les genres proposés jusqu'ici dans cet ordre d'insectes. Tome troisième. Librairie Encyclopédique de Roret, Paris.

Lacordaire J.T. \& Chapuis M.F. 1876. Histoire naturelle des insectes. Genera des coléoptères, ou exposé méthodique et critique de tous les genres proposés jusqu'ici dans cet ordre d'insectes. Tome douzième. Librairie Encyclopédique de Roret, Paris.

Lizardo V., Escobar F. \& Rojas-Soto O. 2017. Diversity and distribution of Phanaeini (Coleoptera: Scarabaeidae: Scarabaeinae) in Mexico. Zootaxa 4358 (3): 271-294.

https://doi.org/10.11646/zootaxa.4358.2.3

López-Guerrero Y. \& Halffter G. 2000. Evolution of the spermatheca in the Scarabaeoidea (Coleoptera). Fragmenta Entomológica, Roma 32: 225-285.

Lucas R. 1920. Catalogus alphabeticus generum et subgenerum Coleopterorum orbis terrarum totius (fam., trib., subtr., sect. incl.). Pars 1. Nicolaische Verlagsbuchhandlung R Stricker, Berlin.

Macleay W.S. 1819. Horae entomologicae: or Essays on the annulose Animals. Vol. I. Part I. S. Bagster, London. https://doi.org/10.5962/bhl.title.48636

Manjarres-H. E.H. \& Molano-R. F. 2015. Estudio de la variación de la genitalia masculina de las especies de la tribu Phanaeini (Scarabaeidae: Scarabaeinae) en Colombia. Boletin Cientifico Centro de Museos, Museo de Historia Natural, Universidad de Caldas 19: 245-257. 
Marchisio E. \& Zunino M. 2012. Il genere Copris Müller. Tassonomia, filogenesi e note di zoogeografia. World Biodiversity Association Monographs 2: 1-176.

Martínez A. 1959. Catálogo de los Scarabaeidae Argentinos. Revista del Museo Argentino de Ciencias Naturales "Bernardino Rivadavia" 5: 1-126.

Martínez A \& Pereira F.S. 1967. Notas escarabeidológicas III (Col. Scarabaeidae-Scarabaeinae). Revista de la Sociedad Entomológica Argentina 29: 53-69.

Mayr E. 1942. Systematics and the Origin of Species from the Viewpoint of a Zoologist. Harvard University Press, Cambridge.

McKenna D.D., Shin S., Ahrens D., Balke M., Beza-Beza C., Clarke D.J., Donath A., Escalona H.E., Friedrich F., Letsch H., Liu S., Maddison D., Mayer C., Misof B., Murin P.J., Niehuis O., Peters R.S., Podsiadlowski L., Pohl H., Scully E.D., Yan E.V., Zhou X., Slipinski A. \& Beutel R.G. 2019. The evolution and genomic basis of beetle diversity. Proceedings of the National Academy of Sciences of the United States of America 116: 24729-24737. https://doi.org/10.1073/pnas.1909655116

Medina C.A. \& Lopera A. 2000. Clave ilustrada para la identificación de géneros de escarabajos coprófagos (Coleoptera: Scarabaeinae) de Colombia. Caldasia 22: 299-315.

Medina C.A., Lopera A., Vítolo. A. \& Gill B. 2001. Escarabajos coprófagos (Coleoptera: Scarabaeinae) de Colombia. Biota Colombiana 2: 131-144.

Medina C.A., Molano F. \& Scholtz C.H. 2013. Morphology and terminology of dung beetles (Coleoptera: Scarabaeidae: Scarabaeinae) male genitalia. Zootaxa 3626 (3): 455-476.

https://doi.org/10.11646/zootaxa.3626.4.3

Michelson A.A. 1911. On metallic colouring in birds and insects. The London, Edinburgh, and Dublin Philosophical Magazine and Journal of Science 6: 554-567.

https://doi.org/10.1080/14786440408637061

Miller S.E., Gordon R.D. \& Howden H.F. 1981. Revaluation of Pleistocene scarab beetles from Rancho La Brea, California (Coleoptera: Scarabaeidae). Proceedings of the Entomological Society of Washington 83: 625-630.

Moctezuma V. \& Halffter G. 2017. A new species of Phanaeus Macleay (Coleoptera: Scarabaeidae: Scarabaeinae) from Los Chimalapas, Oaxaca, Mexico. The Coleopterists Bulletin 71: 47-56.

https://doi.org/10.1649/0010-065X-71.1.47

Moctezuma V. \& Halffter G. 2020. New species and redescriptions of the Onthophagus chevrolati species complex (Coleoptera: Scarabaeoidea: Scarabaeinae). Annales Zoologici 70: 245-261. https://doi.org/10.3161/00034541ANZ2020.70.2.005

Moctezuma V., Halffter G. \& Escobar F. 2016. Response of copronecrophagous beetle communities to habitat disturbance in two mountains of the Mexican Transition Zone: influence of historical and ecological factors. Journal of Insect Conservation 20: 945-956.

https://doi.org/10.1007/s10841-016-9923-5

Moctezuma V., Sánchez-Huerta J.L. \& Halffter G. 2017. Two new species of the Phanaeus endymion species group (Coleoptera, Scarabaeidae, Scarabaeinae). ZooKeys 702: 113-135. https://doi.org/10.3897/zookeys.702.14728

Moctezuma V., Deloya C., Sánchez-Huerta J.L. \& Halffter G. 2019. A new species of the Phanaeus endymion species group (Coleoptera: Scarabaeidae: Scarabaeinae), with comments on ecology and distribution. Annales de la Société entomologique de France (N.S.) 55: 249-254.

https://doi.org/10.1080/00379271.2019.1577170 
Moctezuma V., Nogueira G. \& Halffter G. 2020. A revalidation and a new species in the genus Phanaeus (Coleoptera: Scarabaeoidea: Scarabaeidae: Scarabaeinae). Besoiro 30: 3-11.

https://doi.org/10.5281/zenodo.3675728

Montes de Oca E. 2001. Escarabajos coprófagos de un escenario ganadero típico de la región de Los Tuxtlas, Veracruz, México: Importancia del paisaje en la composición de un gremio funcional. Acta Zoológica Mexicana (n.s.) 82: 111-132.

Moretto P. \& Génier F. 2020. Nouveaux Onthophagus (sensu lato) Latreille, 1802, d'Afrique tropicale appartenant au groupe 23 de d'Orbigny (1913) (Coleoptera, Scarabaeidae, Onthophagini). Catharsius, La Revue 21: 4-23.

Morón M.A. 1979. Fauna de coleópteros lamelicornios de La Estación de Biología Tropical, "Los Tuxtlas", Veracruz, UNAM. México. Anales del Instituto de Biología de la Universidad Nacional Autónoma de México, Serie Zoología 1: 375-454.

Morón M.A. 1985. Fauna de coleópteros lamelicornios de Boca del Chajul, Chiapas, México. Folia Entomológica Mexicana 66: 57-118.

Morón M.A. 1987. The necrophagous Scarabaeinae beetles (Coleoptera: Scarabaeidae) from a coffee plantation in Chiapas, Mexico: habits and phenology. The Coleopterists Bulletin 41: 225-232.

Available from https://www.jstor.org/stable/4008410 [accessed Jul. 2020].

Morón M.A., Camal J.F. \& Canul O. 1986. Análisis de la entomofauna necrófila del área norte de la Reserva de la Biósfera “Sian Ka'an”, Quintana Roo, México. Folia entomológica Mexicana 69: 83-98.

Navarrete D. \& Halffter G. 2008. Dung beetle (Coleoptera: Scarabaeidae: Scarabaeinae) diversity in continuous forest, forest fragments and cattle pastures in a landscape of Chiapas, Mexico: the effects of anthropogenic changes. Biodiversity \& Conservation 17: 2869-2898. https://doi.org/10.1007/s10531-008-9402-8

Nevinson B.G. 1892. Revised Synonymic List of Species in the Genera Phanaeus Macleay and Oxysternon Castelnau. Published privately, London. https://doi.org/10.5962/bhl.title.9416

Nosil P., Feder J.L., Flaxman S.M. \& Gompert Z. 2017. Tipping points in the dynamics of speciation. Nature Ecology and Evolution 1: 0001. https://doi.org/10.1038/s41559-016-0001

Olsoufieff G. d'. 1924. Les Phanaeides (Coleoptera-Lamellicornia). Famille Scarabaeidae - Tr. Coprini. Insecta, Revue illustrée d'Entomologique 13: 4-172.

Pablo-Cea J.D., Velado-Cano M.A. \& Noriega J.A. 2020. A first step to evaluate the impact of ecotourism on biodiversity in El Salvador: a case study using dung beetles in a National Park. Journal of Ecotourism 20: 51-69. https://doi.org/10.1080/14724049.2020.1772798

Pacheco, T.L. \& Vaz-de-Mello F.Z. 2015. Dung beetles of the tribe Phanaeini (Coleoptera: Scarabaeidade: Scarabaeinae) from Roraima state, Northern Brazil: checklist and key to species. Biota Neotropica 15: 1-9. https://doi.org/10.1590/1676-06032015014514

Palacios-Ríos M., Rico-Gray V. \& Fuentes E. 1990. Inventario preliminar de los Coleoptera Lamellicornia de la zona de Yaxchilan, Chiapa, México. Folia Entomológica Mexicana 78: 49-60.

Pessôa S.B. 1934. Contribuição para o conhecimento das espécies brasileiras do gênero Phanaeus. Annales Facultad Medical Sao Paulo 10: 279-314. https://doi.org/10.5962/bhl.title.98039

Pessôa S.B. \& Lane F.1941. Coleópteros necrófagos de interesse médico-legal: ensaio monográfico sobre a família Scarabaeidae de S. Paulo e regiões vizinhas. Arquivos de Zoologia do Estado de São Paulo 2: 389-504. 
Philips T.K., Edmonds W.D. \& Scholtz C.H. 2004. A phylogenetic analysis of the New World tribe Phanaeini: hypotheses on relationships and origins. Insect Systematics and Evolution 35: 43-63. https://doi.org/10.1163/187631204788964664

Pierce W.D. 1946. Descriptions of the dung beetles (Scarabaeidae) of the tar pits. Bulletin of the Southern California Academy of Science 45: 119-131.

Price D.L. 2005. Descriptions of the male and female genitalia of Phanaeus (Macleay) (Scarabaeidae: Scarabaeinae): the vindex species group. The Coleopterists Bulletin 59: 197-203. https://doi.org/10.1649/743

Price D.L. 2007. A phylogenetic analysis of the dung beetle genus Phanaeus (Coleoptera: Scarabaeidae) based on morphological data. Insect Systematics \& Evolution 38: 1-18.

https://doi.org/10.1163/187631207788784058

Price D.L. 2009. Phylogeny and biogeography of the dung beetle genus Phanaeus (Coleoptera: Scarabaeidae). Systematic Entomology 34: 137-150. https://doi.org/10.1111/j.1365-3113.2008.00443.x

Ratcliffe B.C. 2002. A checklist of the Scarabaeoidea of Panama. Zootaxa 32: 1-48. https://doi.org/10.11646/zootaxa.32.1.1

Roze J.A. 1955. Lista preliminar de la familia Scarabaeidae sensu lato de Venezuela. Boletín del Museo de Ciencias naturales 1: 39-63.

Salem H., Kirsch R., Pauchet Y., Beresategui A., Fukumori K., Moriyama M., Cripps M., Windsor D., Fukatsu T. \& Gerardo N.M. 2020. Symbiont digestive range reflects host plant breadth in herbivorous beetles. Current Biology 30: 2875-2886. https://doi.org/10.1016/j.cub.2020.05.043

Salomão R.P., Favila M.E. \& González-Tokman D. 2020. Spatial and temporal changes in the dung beetle diversity of a protected, but fragmented, landscape of the northernmost Neotropical rainforest. Ecological Indicators 111: 105968. https://doi.org/10.1016/j.ecolind.2019.105968

Sánchez-de-Jesús H.A., Arroyo-Rodríguez V., Andresen E. \& Escobar F. 2016. Forest loss and matrix composition are the major drivers shaping dung beetle assemblages in a fragmented rainforest. Landscape Ecology 31: 843-854. https://doi.org/10.1007/s10980-015-0293-2

Sánchez-Hernández G., Gómez B., Delgado L., Rodríguez-López M.E. \& Chamé-Vázquez E.R. 2018. Diversidad de escarabajos copronecrófagos (Coleoptera: Scarabaeidae: Scarabaeinae) en la Reserva de la Biosfera Selva El Ocote, Chiapas, México. Caldasia 40: 144-160.

https://doi.org/10.15446/caldasia.v40n1.68602

Sánchez-Hernández G., Gómez B., Chamé-Vázquez E.R., Dávila-Sánchez R.A., RodríguezLópez M.E \& Delgado L. 2020. Current status of dung beetles (Coleoptera, Scarabaeidae, Scarabaeinae) diversity and conservation in Natural Protected Areas in Chiapas (Mexico). Neotropical Biology \& Conservation 15: 219-244. https://doi.org/10.3897/neotropical.15.e53762

Santos-Heredia C., Andresen E., Zárate D.A. \& Escobar F. 2018. Dung beetles and their ecological functions in three agroforestry systems in the Lacandona rainforest of Mexico. Biodiversity \& Conservation 27: 2379-2394. https://doi.org/10.1007/s10531-018-1542-x

Solís A. \& Kohlmann B. 2012. Checklist and distribution atlas of the Scarabaeinae (Coleoptera: Scarabaeidae) of Costa Rica. Zootaxa 3482: 1-32.

Suárez-Moo P., Cruz-Rosales M., Ibarra-Laclette E., Desgarennes D., Huerta C. \& Lamelas A. 2020. Diversity and composition of the gut microbiota in the developmental stages of the dung beetle Copris incertus Say (Coleoptera, Scarabaeidae). Frontiers in Microbiology 11: 1698.

https://doi.org/10.3389/fmicb.2020.01698 
Tarasov S. \& Génier F. 2015. Innovative Bayesian and parsimony phylogeny of dung beetles (Coleoptera, Scarabaeidae, Scarabaeinae) enhanced by ontology-based partitioning of morphological characters. PLoS One 10: e0116671. https://doi.org/10.1371/journal.pone.0116671

Tarasov S.I. \& Solodovnikov A.Y. 2011. Phylogenetic analyses reveal reliable morphological markers to classify mega-diversity in Onthophagini dung beetles (Coleoptera: Scarabaeidae: Scarabaeinae). Cladistics 27: 1-39. https://doi.org/10.1111/j.1096-0031.2011.00351.x

Thiyonila B., Reneeta N.P., Kannan M., Shantkriti S. \& Krishnan M. 2018. Dung beetle gut microbes: Diversity, metabolic and immunity related roles in host system. International Journal of Scientific Innovations 1: 77-83.

Vargas W.E., Avendano E., Hernández-Jiménez M., Azofeifa D.E., Libby E., Solís A. \& BarbozaAguilar C. 2018. Photonic crystal characterization of the cuticles of Chrysina chrysargyrea and Chrysina optima jewel scarab beetles. Biomimetics 3: 30. https://doi.org/10.3390/biomimetics3040030

Vaz-de-Mello F.Z., Edmonds W.D., Ocampo F.C., Schoolmeesters P. 2011. A multilingual key to the genera and subgenera of the subfamily Scarabaeinae of the New World (Coleoptera: Scarabaeidae). Zootaxa 2854 (1): 1-73. https://doi.org/10.11646/zootaxa.2854.1.1

Vítolo A.L. 2000. Clave para la identificación de los géneros y especies Phanaeinas de Colombia. Revista de la Academia Colombiana de Ciencias Exactas Físicas y Naturales 24 (93): 591-601.

Vulcano M.A. \& Pereira F.S. 1967. Sinópse dos Passalidae e Scarabaeidae s. str. da região Amazônica (Insecta, Coleoptera). Atas do Simpósio sôbre a Biota Amazônica 5: 533-603.

Vulinec C. 1997. Iridescent dung beetles: A different angle. Florida Entomologist 80: 132-141.

https://doi.org/10.2307/3495550

Werner M. \& Simmons L.W. 2008. The evolution of male genitalia: functional integration of genital sclerites in the dung beetle Onthophagus taurus. Biological Journal of the Linnean Society 92: 257-266. https://doi.org/10.1111/j.1095-8312.2007.00924.x

Wheeler Q.D. \& Platnick N.I. 2000. The phylogenetic species concept (sensu Wheeler and Platnick). In: Wheeler Q.D. \& Meier R. (eds) Species Concepts and Phylogenetic Theory: 55-69. Columbia University Press, New York.

Yao F., Shi B., Wang X., Pan D., Bai M., Yan J., Cumberlidge N. \& Sun H. 2020. Rapid divergent coevolution of Sinopotamon freshwater crab genitalia facilitates a burst of species diversification. Integrative Zoology 15: 174-186. https://doi.org/10.1111/1749-4877.12424

Zachos F.E. 2016. Species Concepts in Biology. Historical Development, theoretical Foundations and practical Relevance. Springer International Publishing, Switzerland.

https://doi.org/10.1007/978-3-319-44966-1

Zaragoza-Caballero S., Rodríguez-Mirón G.M., Vega-Badillo V., González-Ramírez M., Zurita-García M.L., Domínguez-León D.E., López-Pérez S., Gutiérrez-Carranza I.G., Cifuentes-Ruíz P., PérezHernández C.X., Ramírez-del-Valle E. \& Gutiérrez N. 2019. A checklist of the Coleoptera (Insecta) from Morelos, Mexico. Zootaxa 4580: 1-122. https://doi.org/10.11646/zootaxa.4580.1.1

Manuscript received: 15 July 2020

Manuscript accepted: 20 December 2020

Published on: 28 April 2021

Topic editor: Nesrine Akkari 
Section editor: Max Barclay

Desk editor: Kristiaan Hoedemakers

Printed versions of all papers are also deposited in the libraries of the institutes that are members of the EJT consortium: Muséum national d'histoire naturelle, Paris, France; Meise Botanic Garden, Belgium; Royal Museum for Central Africa, Tervuren, Belgium; Royal Belgian Institute of Natural Sciences, Brussels, Belgium; Natural History Museum of Denmark, Copenhagen, Denmark; Naturalis Biodiversity Center, Leiden, the Netherlands; Museo Nacional de Ciencias Naturales-CSIC, Madrid, Spain; Real Jardín Botánico de Madrid CSIC, Spain; Zoological Research Museum Alexander Koenig, Bonn, Germany; National Museum, Prague, Czech Republic. 